2015

\title{
ECOPHYSIOLOGICAL RESPONSES OF SUGAR MAPLE ROOTS TO CLIMATIC CONDITIONS
}

Mickey Philip Jarvi

Michigan Technological University

Follow this and additional works at: https://digitalcommons.mtu.edu/etds

Part of the Biology Commons, and the Ecology and Evolutionary Biology Commons Copyright 2015 Mickey Philip Jarvi

\section{Recommended Citation}

Jarvi, Mickey Philip, "ECOPHYSIOLOGICAL RESPONSES OF SUGAR MAPLE ROOTS TO CLIMATIC CONDITIONS", Dissertation, Michigan Technological University, 2015.

https://doi.org/10.37099/mtu.dc.etds/1015

Follow this and additional works at: https://digitalcommons.mtu.edu/etds

Part of the Biology Commons, and the Ecology and Evolutionary Biology Commons 
ECOPHYSIOLOGICAL RESPONSES OF SUGAR MAPLE ROOTS TO CLIMATIC CONDITIONS

\author{
By \\ Mickey Philip Jarvi
}

\begin{abstract}
A DISSERTATION
Submitted in partial fulfillment of the requirements for the degree of DOCTOR OF PHILOSOPHY

In Forest Science
\end{abstract}

MICHIGAN TECHNOLOGICAL UNIVERSITY

2015

(C) 2015 Mickey P. Jarvi 
This dissertation has been approved in partial fulfillment of the requirements for the Degree of DOCTOR OF PHILOSOPHY in Forest Science

School of Forest Resources and Environmental Science

Dissertation Advisor: $\quad$ Andrew Burton

Committee Member: $\quad$ Molly Cavaleri

Committee Member: $\quad$ Linda Nagel

Committee Member: $\quad$ Shiliang $W u$

School Dean: Terry Sharik 


\section{Table of Contents}

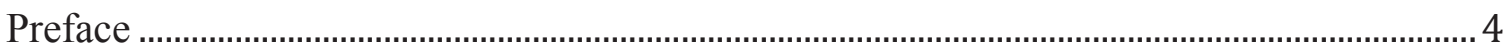

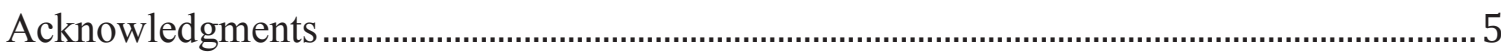

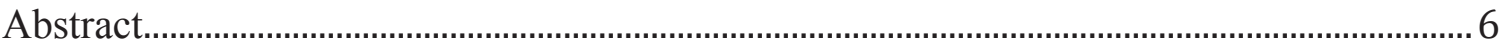

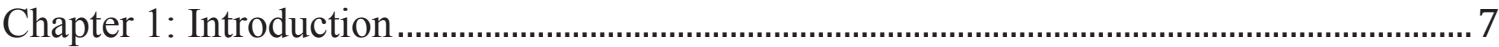

Chapter 2: Adenylate control contributes to thermal acclimation of sugar maple fine root respiration in experimentally warmed soil ${ }^{1}$..................................................................... 11

Chapter 3: Root respiration and biomass responses to experimental soil warming vary

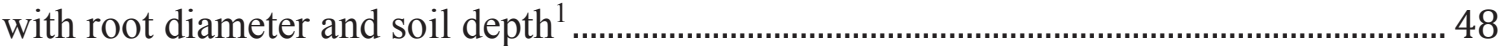

Chapter 4: Ecosystem root respiration in sugar maple forests increases with temperature within populations but not across populations: Results of a range-wide study ${ }^{1}$................. 71

Chapter 5: Conclusion..............................................................................................................113 


\section{Preface}

Chapter 2 has been through the peer review process for the journal Plant, Cell and Environment once and was received well but needed revisions before publication. Andrew Burton is co-author on this paper and has assisted with data interpretation and manuscript editing. Mickey Jarvi designed the experiment, collected data, prepared samples, analyzed data, conducted statistical analysis, wrote, and edited for both chapters. The final manuscript with revisions will be submitted to Plant, Cell and Environment shortly after the acceptance of this dissertation. Andrew Burton will be the other author.

Chapters $3 \& 4$ have not been submitted to a peer reviewed journal as of this time, but will be prepared for publication shortly after the acceptance of this dissertation.

These chapters have been written solely by Mickey Jarvi; however, Andrew Burton will edit the manuscript throughout before publication and be included as a co-author on both articles. Mickey Jarvi designed the experiment, collected data, prepared samples, analyzed data, conducted statistical analysis, wrote, and edited for both chapters. Andy Burton assisted in data interpretation and editing for both chapters.

An embargo will be in place on this dissertation for one year (365 days) starting August $10^{\text {th }} 2015$ and ending August $10^{\text {th }} 2016$ to allow publication of Chapters 2, 3, and 4 before publication of this $\mathrm{PhD}$ dissertation is available. 


\section{Acknowledgments}

First and foremost I would like to dedicate this $\mathrm{PhD}$ dissertation to my parents: Frederick and Suzanne Jarvi. You have raised me to be a free thinker and never to take the first answer for what it is. You pushed me to always strive to ask "why" and "what if" and it has made me into the person that I am today.

Secondly, I would like to thank wholeheartedly the overwhelming love and support of Gina Testa. You have been my rock and my star and a lot of this dissertation would not have been completed without you.

I would like to thank every undergraduate student, graduate student, friend, colleague, and teacher that has been a part of my life while at Michigan Technological University. I have had the opportunity to learn, teach, and laugh with some of the brightest people I have ever known.

I would like to individually thank Andrew Burton for everything that he has done for me. I started in his lab as a young undergraduate student sorting sugar maple roots never knowing that decision would lead me down this path. He has been a great friend, supervisor, mentor, and advisor and without his guidance I would not be here today.

Thank you to Molly Cavaleri, Linda Nagel, and Shiliang Wu to be willing to serve on my $\mathrm{PhD}$ committee. Your words of encouragement and positive criticism helped me through many days and nights throughout this journey.

Finally, I would like to personally thank several individuals for assistance in the office, field, and laboratory: Kenneth Carruthers, Steve Rummel-Chadderdon, Adam Coble, Alex Collins, Akwasi Duah-Gyamfi, Emmanuel Ebanyenle, Jennifer Eikenberry, Randy Harrison, Peter Hoch, Jerry Jondreau, Kevyn Juneau, Carley Kratz Andy Maday, and Alex Mehne. Especially, Michael Adam Stanley, I will never be able to repay you with the help you gave me. 


\section{Abstract}

The severity of future climate change resulting from anthropogenic alteration of the global $\mathrm{C}$ cycle will depend in part on feedbacks between atmospheric greenhouse gases and forest ecosystem carbon balance, but how these two systems will interact is not entirely understood. Forests are both major sinks and sources for atmospheric $\mathrm{CO}_{2}$ through the processes of photosynthesis and ecosystem respiration. The balance between these two processes could be altered if autotrophic respiration were to increase exponentially with temperature as climate warms. Root respiration, and especially fineroot respiration ( $<1 \mathrm{~mm}$ diameter), is a major contributor to total ecosystem $\mathrm{C}$ exchange. A study to assess long-term responses of root respiration to warmer soil conditions was conducted at the SMART (sugar maple altered rainfall and temperature) experiment located in Alberta, MI at the Michigan Technological University's Ford Center and Forest. It was found that acclimation of fine-root respiration in this system was not due to an insufficient supply of carbohydrates from photosynthesis (substrate limitation), but was the result of adenylate control. As a result, fine root respiration was constrained to levels needed to perform work required of the fine roots (e.g. nutrient acquisition).

Acclimation also occurred for roots $1-2 \mathrm{~mm}$ in diameter at the $0-10 \mathrm{~cm}$ soil depth, but not in any roots larger than $2 \mathrm{~mm}$ or in roots of any size at deeper soil depths. As a result, at the ecosystem level, total root system respiration was $60 \%$ greater in warmed soil than in unwarmed soil. The studies in experimentally warmed sugar maple forests were complemented by an examination of fine-root respiration and root biomass at sixteen sugar maple forests located across a latitudinal gradient across sugar maple's native range, spanning approximately $10{ }^{\circ} \mathrm{C}$ of mean annual temperature. Sugar maple in the southern, warmer sites had lower root $\mathrm{N}$, lower specific fine-root respiration at a given temperature, and less fine-root biomass than that from the northern cooler regions. Fine root respiration at ambient soil temperature actually decreased from north to south, despite a nearly $10{ }^{\circ} \mathrm{C}$ increase in soil temperature. However, within sites respiration measured across three sample dates did increase with temperature. The next big question is whether these adjustments that exist across sugar maple's range are plastic responses to 1 local climate or result from genotypic differences among populations in different locations. If the former is true, all sugar maple would be capable of acclimation, reduction in root biomass, and/or reduction in root $\mathrm{N}$ as mechanisms for dealing with climatic warming, and sugar maple would have a large capacity to adjust to future climate change. The latter would suggest that predicted rates of climatic warming could have negative impacts on this important species across its entire current range. The lack of changes in fine root biomass and root $\mathrm{N}$ concentration at the SMART study location after four plus years of soil warming support the possibility that differences along the latitudinal transect are largely the result of inherent genetic differences among population. 


\section{Chapter 1: Introduction}

This dissertation was designed to investigate how sugar maple (Acer saccharum Marsh.) forests can adapt to rising temperatures associated with global climate change. Particularly, these chapters primarily investigated how sugar maple root respiration might adjust to climate change. Currently, the Intergovernmental Panel on Climate Change (IPCC) predicts that the global temperature will rise by $4.5-7.2^{\circ} \mathrm{C}$ by the year 2100 with sometimes drastic changes in precipitation patterns (IPCC 2013, Karl et al. 2009). Forested ecosystems contain a vast proportion of the world's carbon (Goodale et al. 2002), and help regulate temperature and weather patterns across the globe through evapotranspiration and $\mathrm{C}$ exchange with the atmosphere. In fact, respiration from forested ecosystems returns more $\mathrm{C}$ to the atmosphere than the combustion of fossil fuels

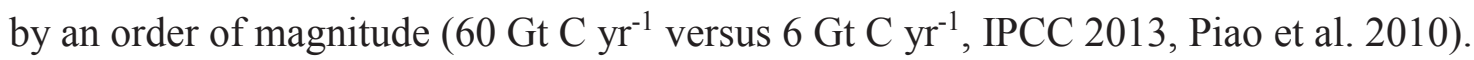
However, fossil fuel $\mathrm{C}$ has been sequestered for millions of years, while autotrophic respiration is "younger" carbon and has been fixed from the atmosphere recently. It is this slow and steady increase in fossil fuel based $\mathrm{C}$ that has been the leading cause of climate change since the industrial revolution of the 1800s (IPCC 2013). All carbon fixed through photosynthesis is gross primary productivity (GPP). Autotrophic respiration (respiration of organisms that obtain their organic $\mathrm{C}$ through photosynthesis or chemosynthesis) is often exponentially sensitive to temperature, and a byproduct of this respiration is $\mathrm{CO}_{2}$. Gross primary productivity minus autotrophic respiration is defined as net primary productivity (NPP) and can be a good measure of the strength of the carbon sink, or source, that forests comprise. Increases in global temperatures may cause 
autotrophic respiration to increase and thus may potentially affect NPP in addition to returning more $\mathrm{C}$ to the atmosphere, which may induce a positive feedback loop with more greenhouse gases causing more global climate change (Woodwall and Mackenzie 1995). Trees may be capable of adjustments and may be able to acclimate to increases in temperature or changes in soil moisture. It is important to investigate different mechanisms by which tree systems might adjust to changes in climate at a single location to remove as many spatial biases as possible, and to also investigate mechanisms that tree species have used to adapt to differences in climate across their entire native ranges. This latter effort would allow for inferences regarding how well a species may be adapted to future climate change. This dissertation investigated both of these scenarios.

Chapter 2 describes a study conducted from 2011-2013 to investigate the physiological mechanisms associated with previously documented acclimation of fineroot respiration in sugar maple to experimental increases in soil temperature (Jarvi and Burton 2013). This study occurred at the SMART experiment (sugar maple altered rainfall and temperature) in Alberta Michigan at the Michigan Technological University's Ford Center and Forest. This study was located in a natural sugar maple forest and utilized a fully factorial soil warming and supplemental precipitation design, with three replicates per treatment, initiated in 2010 . The soil warming was applied through the use of sixteen infrared heating lamps situated $1.5 \mathrm{~m}$ above soil surface for each $10 \mathrm{~m}$ by $10 \mathrm{~m}$ research plot. Substrate limitation (carbohydrate supply) and adenylate control (a cellular level control on respiration as a measure of capacity) were tested as two potential constraints on surface soil ( $0-10 \mathrm{~cm}$ depth) fine-root $(<1 \mathrm{~mm})$ respiration. These fine 
roots are at the depth where the majority of nutrient acquisition takes places and therefore where the highest levels of root respiration occur.

The research described in Chapter 3 was conducted at the SMART experiment in late summer of 2013. This study determined if the partial thermal acclimation observed for respiration of fine roots $(<1 \mathrm{~mm})$ in the surface soil was also occurring for multiple root diameters $(<1,1-2$, and 2-10 mm) and at different soil depths $(0-10,10-20$, and 30$50 \mathrm{~cm}$ ). Understanding what is occurring at the root level for these different depths and root classes allowed for an estimate of changes in overall ecosystem root respiration $\left(\mu \mathrm{mol} \mathrm{CO}_{2} \mathrm{~m}^{-2}\right.$ season $^{-1}$ ) to assess if sugar maple is ultimately adjusting its $\mathrm{C}$ usage effectively to remain competitive and active in the experimentally warmed environment, and thus if it has the potential to do so in response to future warmer climatic conditions.

Finally, Chapter 4 describes a study conducted across a latitudinal gradient encompassing sugar maple's native range. This study spanned 10 degrees of latitude and $\mathrm{a} \sim 10{ }^{\circ} \mathrm{C}$ difference in mean annual temperature (MAT) across sixteen study locations. The sites all had similar basal area dominance by sugar maple. This study was conducted during June, July, and September 2014 and fine-root $(<1 \mathrm{~mm})$ respiration and root biomass at 0-10 and 10-20 $\mathrm{cm}$ were examined for the purposes of comparing the sites in terms of metabolic capacity, fine root $\mathrm{N}$, specific fine-root respiration rates, and root biomass. This study was particularly novel in trying to determine mechanisms by which sugar maple root systems adjusted to temperature across its range and if simple modeling techniques could be applied to predicting responses of respiration rates to rising temperatures associated with future climate change. 


\section{References}

Goodale C.L., Apps M.J., Birdsey R.A., Field C.B., Heath L.S., Houghton R.A., Jenkins J.C., Kohlmaier G.H., Kurz W., Liu S., Nabuurs G., Nilsson S., Shvidenko A.Z. (2002). Forest carbon sinks in the Northerm Hemisphere. Ecological Applications. 12: 891-899.

IPCC (2013): Summary for Policymakers. In: Climate Change 2013: The Physical Science Basis. Contribution of Working Group I to the Fifth Assessment Report of the Intergovernmental Panel on Climate Change [Stocker, T.F., D. Qin, G.-K. Plattner, M. Tignor, S.K. Allen, J. Boschung, A. Nauels, Y. Xia, V. Bex and P.M. Midgley (eds.)]. Cambridge University Press, Cambridge, United Kingdom and New York, NY, USA.

Jarvi M.P., Burton A.J. (2013). Acclimation and soil moisture constrain sugar maple root respiration in experimentally warmed soil. Tree physiology,33(9), 949-959.

Karl T., Melillo J., Peterson T., Hassol S.J. (2009). Global climate change impacts in the United States: a state of knowledge report from the US global change research program. Cambridge: Cambridge University Press.

Piao S., Luyssaert S., Ciais P., Janssens I.A., Chen A., Cao C., Fang J., Friedlingstein P., Luo Y., Wang S. (2010). Forest annual carbon cost: a global-scale analysis of autotrophic respiration. Ecology. 91(3):652-661.

Woodwell G.M., Mackenzie F.T. (eds.) (1995). Biotic feedbacks in the global climatic system: will the warming feed the warming? Oxford University Press, Oxford. 


\title{
Chapter 2: Adenylate control contributes to thermal acclimation of sugar maple fine root respiration in experimentally warmed soil ${ }^{1}$
}

\begin{abstract}
We investigated the occurrence of and mechanisms responsible for acclimation of fineroot respiration of mature sugar maple (Acer saccharum Marsh.) after 3+ years of experimental soil warming. Experimental treatments included soil warming $\left(+4-5{ }^{\circ} \mathrm{C}\right)$ in a factorial combination with soil moisture addition. Fine-root respiration was measured every two to four weeks during the growing season. Assessments of potential mechanisms for thermal acclimation included changes in enzyme capacity as indicated by root N; substrate limitation assessed by examining non-structural carbohydrates and effects of exogenous sugars; and responses to a respiratory decoupling agent (CCCP) to test for adenylate control. Partial acclimation of fine-root respiration occurred in response to soil warming throughout the study, causing specific root respiration to increase to a much lesser degree (14 to $27 \%$ ) than would be expected for a 4 to $5{ }^{\circ} \mathrm{C}$ temperature increase. We found no evidence that enzyme or substrate limitation caused acclimation, but did find evidence supporting adenylate control. The uncoupling agent caused a $1.4 \mathrm{x}$ greater stimulation of respiration in roots from warmed soil. Sugar maple fine-root respiration in warmed soil was at least partially constrained by adenylate use, likely limiting respiration to that needed to support work being performed by the root system.

${ }^{1}$ The material contained in this chapter was submitted to Plant, Cell and Environment and was returned for revisions. Mickey Jarvi designed the experiment, collected data, analyzed data, wrote manuscript, and edited manuscript. Andrew Burton is listed as a second author and assisted Mickey Jarvi with data analysis and interpretation and manuscript edits.
\end{abstract}




\section{Introduction}

Plant respiration returns 50-60 Gt C annually to the atmosphere (Gifford 2003). This process equals approximately $30-80 \%$ the daily photosynthetic $\mathrm{C}$ gain (Loveys et al. 2002, Amthor 2000). Conversely, fossil fuel emissions are about $8.7 \mathrm{Gt} \mathrm{C} \mathrm{yr}^{-1}$ (Boden et al. 2012). For forests, it has been suggested that ecosystem respiration, not photosynthesis, is the main component of net ecosystem $\mathrm{C}$ exchange (Valentini et al. 2000). Therefore, the degree to which respiration rates change as temperatures warm may determine the C sink strength of terrestrial ecosystems (Smith and Dukes 2013, Grace and Rayment 2000). If plant respiration does not adjust to climatic warming, the potential respiratory increases with temperature could catalyze a positive feedback loop that accelerates rates of atmospheric $\mathrm{CO}_{2}$ increase and resultant climatic warming (Woodwell and Mackenzie 1995). A greater return of assimilated C to the atmosphere through plant tissue respiration also could potentially decrease $\mathrm{C}$ available for biomass production, if annual assimilation does not increase sufficiently to compensate.

Acclimation can be defined as: "A physiological, structural, or biochemical adjustment by an individual plant in response to an experimentally induced environmental stimulus that is manifested as alterations in the short-term response function of a physiological process" (Smith \& Dukes 2013); however, this phenomenon is not necessarily restricted to experiments and can be found naturally (Atkin et al. 2000b, Niinemets and Valladares 2004, Wagner et al. 1996, Larigauderie and Körner 1995). If plant tissues thermally acclimate to warmer temperatures, the potential negative impacts of warmer temperatures on plant and ecosystem net $\mathrm{C}$ gain would be greatly reduced, but 
the degree to which respiration of different tissues will acclimate to long-term increases in temperature is not fully understood. Acclimation has been found to occur in both leaves (Slot and Kitajima 2015, Gunderson et al. 2010, Kositsup et al. 2009, Medlyn et al. 2002, Atkin et al. 2000b, Larigauderie \& Körner 1995) and root of trees (Jarvi \& Burton 2013, Bryla et al. 1997). However, the relative amount of data on acclimation for root systems is rather limited when compared that for leaves (Vogel et al. 2014, Hopkins et al. 2013, Jarvi and Burton 2013), and very little of the available data for temperature acclimation of fine-roots to in situ soil warming field experiments.

How root systems respond to changes in climate at the ecosystem level can be important as roots can contribute to $50-60 \%$ of total soil respiration in forested ecosystems (Hanson et al. 2000). Currently, responses primarily from small-scale and short-term experimental alterations of environmental conditions are used to drive Earth system models, such as those used by the Intergovernmental Panel on Climate Change to predict responses to future climatic conditions (Collins et al. 2011). However, larger scale and longer-term changes, including acclimation, biochemical feedbacks, and adaptation are rarely represented in these models (Smith \& Dukes 2013). This is especially important for root system respiration, which is often modeled using simple relationships such as exponential increases with temperature, using tissue $\mathrm{N}$ or root diameter as an indicator of root activity, or allocating a fixed proportion of assimilated C for belowground use (Himmelbauer et al. 2004, Högberg et al. 2002, Zogg et al. 1996).

The objective of this study was to assess the presence of and possible mechanisms for thermal acclimation of fine-root respiration in a mature sugar maple forest subjected 
to long-term soil warming. We have previously shown partial acclimation of sugar maple fine-root $(<1 \mathrm{~mm}$ diameter) respiration during the first year of experimental soil warming (Jarvi \& Burton 2013). Here we report longer-term (3-yr) responses of root respiration to experimentally warmed $\left(+4\right.$ to $\left.5{ }^{\circ} \mathrm{C}\right)$ soil and examine three potential mechanisms for this acclimation: altered enzymatic capacity, substrate limitation and adenylate control. It is after this 3-yr time period that we assume that all the fine-roots grown in the treatment areas have turned over and have grown entirely subjected to the individual treatments based on previous work with sugar maple fine roots having a turnover rate at 2-3 years (Fahey et al. 2012, Burton et al. 2000). Altered enzymatic capacity could occur over time if new roots were constructed with lower levels of enzymes responsible for catalyzing the reactions responsible for root respiration (Atkin \& Tjoelker 2003). Substrate limitation would indicate acclimation occurred because the supply of carbohydrates to the roots was insufficient to support the sustained large increases in metabolic activity that potentially could occur in warmer soil (Covey-Crump et al. 2002). Adenylate control would indicate that the respiratory capacity at warmer temperatures exceeded that needed to support work being performed by roots for processes such as nutrient uptake and transport (Atkin and Tjoelker 2003). If this occurred, more adenosine triphosphate (ATP) would be produced than was required for cell processes, leading to elevated ATP:ADP ratios or low adenosine diphosphate (ADP) concentration causing down regulation of respiration (Douse and Neuburger 1989).

Possible changes in enzymatic capacity were assessed by analyzing fine-root tissue $\mathrm{N}$ concentration across time for warmed and unwarmed soil. It is fundamental that 
fine-root respiration may be correlated positively to tissue $\mathrm{N}$ because of the role of proteins containing N play in photosynthesis and respiration. Previous work has found that both angiosperms and gymnosperms exhibit a positive relationship between root respiration and root nitrogen (Reich et al. 1998). Additionally, the review conducted by Cotrufu et al. (1998) explains that plant tissue $\mathrm{N}$ is a fundamental factor controlling substrate use and growth rate. Substrate limitation was tested using two methods: 1) analyzing fine-root non-structural carbohydrate concentrations; and 2) examining the response of fine-root respiration to exogenous sugar additions. Adenylate control was tested using an uncoupling agent: carbonyl cyanide m-chlorophenylhydrazone (CCCP) (Drake et al. 2008, Covey-Crump et al. 2002). CCCP dissipates the $\mathrm{H}^{+}$gradient of the mitochondria and allows respiration to proceed without production of ATP, eliminating reductions in respiration associated with elevated ATP:ADP ratios or low ADP concentration (Atkin \& Tjoelker 2003) that could occur when ATP production exceeds cell metabolic requirements.

\section{Materials and methods}

\section{Study Site}

The study was conducted at Michigan Technological University’s Ford Center

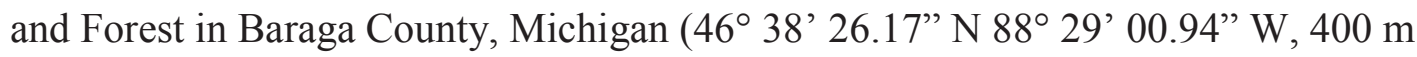
elevation). The sugar maple altered rainfall and temperature (SMART) experiment was located in a mature northern hardwood forest with sugar maple comprising $89.3 \%(21.7$ $\mathrm{m}^{2} \mathrm{ha}^{-1}$ ) of the overstory basal area (Jarvi \& Burton 2013) and $75.4 \%$ of overstory density 
$\left(725.9\right.$ trees $\left.\mathrm{ha}^{-1}\right)$. Minor species present included: American elm (Ulmus americana L., eastern hemlock (Tsuga canadensis (L.) Carr.), ironwood (Ostrya virginiana (Mill.) K. Koch), and yellow birch (Betula alleghaniensis Britton). The total basal area at the site is $24.3 \mathrm{~m}^{2} \mathrm{ha}^{-1}$, with 962.0 trees ha- ${ }^{-1}$. The dominant trees at this location are 100 years or more in age. The soil is classified as a Kallio cobbly silt loam (coarse-loamy, mixed, supaeractive, frigid Oxyaquic Fragiorthods). This soil consists of a cobbly silt loam and silt loam to a depth of $40 \mathrm{~cm}$, with a fragipan occurring at $\sim 40 \mathrm{~cm}$. Soil textures below the fragipan include sandy loams and gravelly loams to a depth of $150 \mathrm{~cm}$.

\section{Experimental Treatments}

The SMART experiment utilized a fully factorial study design consisting of twelve $-10 \mathrm{~m}$ x $10 \mathrm{~m}$ plots with each of four treatments replicated three times. The treatments included a control, heat (soil warming to 4 to $5^{\circ} \mathrm{C}$ above ambient), water (addition of $30 \%$ of average growing season ambient rainfall), and the combination of heat + water. The rate of water addition was intended to offset enhanced evaporative moisture loss due to soil warming, resulting in soil moisture similar to that for the control treatment. The heated plots each had sixteen infrared heating lamps (model MRM1215 heaters, Kalglo Electronic Co., Bethlehem, PA, USA) situated $1.5 \mathrm{~m}$ above soil surface, with four rows of four lamps spaced $2.5 \mathrm{~m}$ apart. The lamp's heat output was adjusted manually as needed to achieve the desired increase in soil temperature. Treatments were initiated in September 2010 and continued during 2011, 2012, and 2013. The lamps were kept on 24 hours per day from 17 Sep through 16 Nov in 2010, 22 Apr through 11 Nov in 2011,25 Mar through 24 Oct in 2012, and 2 May through 24 Sep in 2013. Due to 
funding constraints, a slightly lower temperature differential $\left(3\right.$ to $\left.4{ }^{\circ} \mathrm{C}\right)$ was used in 2013 . In the spring of 2012 and falls of 2011 and 2012, heat was gradually ramped up (or down) over a period of two to three weeks.

The water additions were applied via sprinkler heads positioned on the four corners of the $10 \mathrm{~m} \times 10 \mathrm{~m}$ plots. Each covered a $90^{\circ}$ field of application, with slight overlap at plot center to ensure even and complete distribution of water throughout the plot. Precipitation was collected in 1,900 L tanks with the use of a gutter system attached to nearby Ford Center building $(\sim 500 \mathrm{~m})$ and moved to the SMART experimental site with the use of an all-terrain forklift. Water additions were applied weekly from the tank via pump and sprinkler, in association with natural rain events when possible, to allow for natural wetting and drying cycles while maintaining soil moisture in the heat + water treatment at levels close to those of the control plot. A total of $16 \mathrm{~cm}$ of precipitation equivalent was added annually between mid-May and mid-October.

To monitor treatment effectiveness, temperature probes and soil moisture probes were placed throughout the experimental plots including: 2, 5, and $10 \mathrm{~cm}$ soil depths beneath heater rows, and at 2 and $5 \mathrm{~cm}$ depths midway between heater rows (Em50 data loggers with 5TM temperature/moisture probes, Decagon Devices Inc., Pullman, Washington, USA).

\section{Fine-root respiration}

Fine-root respiration ( $<1 \mathrm{~mm}$ diameter) was measured with open-system infrared gas analyzers (IRGA, CIRAS-I and II, PP Systems) every two to four weeks during the 
snow free season. On all sample dates, measurements were made at the ambient soil temperature for the particular sample date and at a common reference temperature of 18 ${ }^{\circ} \mathrm{C}$. Comparing respiration rates at a common reference temperature is one way to assess the existence of acclimation to increased temperature (Atkin et al. 2000b). After initiation of experimental treatments, measurements of fine-root respiration were made on five dates from September to November in 2010; six dates from May to September in 2011, eight dates from March to October in 2012, and eight dates from May to September in 2013.

Excised fine roots were collected using $5 \mathrm{~cm}$ wide by $10 \mathrm{~cm}$ deep cylindrical soil cores. Three cores were taken per plot per sample date. These samples were taken from the inner $5 \mathrm{~m} \times 5 \mathrm{~m}$ portion of the experimental plots, to ensure they contained roots from trees for which a majority of the root system was warmed. The roots were hand-cleansed of soil, and approximately $2 \mathrm{~g}$ fresh weight of woody tree fine roots $(<1 \mathrm{~mm}$ diameter $)$ were placed in the IRGA cuvette (Burton et al. 2012, Jarvi and Burton 2013). Woody tree roots were visually separated from understory herbaceous roots based on morphological differences. The IRGA root cuvette is solid aluminum $12 \mathrm{~cm}$ tall with an inside chamber volume of $76 \mathrm{~cm}^{3}$ (Burton \& Pregitzer 2002). The IRGA cuvette had a foam gasket between cuvette lid and cuvette to ensure no leakage could occur (Burton \& Pregitzer 2002). The IRGA is allowed 30 minutes of warm-up period, and the machine is zeroed to ensure no leakage before the measurement of samples. Live roots were distinguished from dead roots by white, tan or brown coloration and a smooth appearance. Dead roots were brittle, had rough edges and dark brown or black 
coloration. Visual observations of root morphology during sorting suggested that the proportion of sample mass comprised of sugar maple roots was similar to the proportion of sugar maple basal area at the site.

An input $\mathrm{CO}_{2}$ of $1000 \mu \mathrm{l} \mathrm{l}^{-1}$ was used for all measurements. This value generally approximates the concentration of $\mathrm{CO}_{2}$ in shallow soil atmosphere of sugar maple forests in Michigan (Burton et al. 1997). The cuvette bases were placed in water baths to maintain the respiration samples at the desired temperatures. The samples were allowed to equilibrate to measurement conditions for 15 minutes prior to recording of respiration rates. All samples were measured for $\mathrm{CO}_{2}$ efflux within 45 minutes after being excised from the tree system. Measurements based on previous work indicate that fine-root respiration may decrease by $10 \% 15$ minutes after excision, so therefore, final measurements were adjusted accordingly. After sample efflux rates (nmol $\left.\mathrm{CO}_{2} \mathrm{~s}^{-1}\right)$ had been determined, the samples were placed on ice and returned to the lab. Samples in the lab were then subsequently cleansed with deionized water to remove any adhering soil that was not removed during the field cleaning and dried in an oven at $65{ }^{\circ} \mathrm{C}$ for 48 hours. After dry weights were obtained, specific fine-root respiration rates (nmol $\left.\mathrm{CO}_{2} \mathrm{~g}^{-1} \mathrm{~s}^{-1}\right)$ were determined by dividing the flux rate obtained in the field by sample dry mass. Samples were subsequently ground to a fine powder (8000M Mixer/Mill, Spex SamplePrep LLC, Metuchen, NJ) and analyzed for nitrogen (N) concentration with an elemental analyzer (Carlo Erba NA 1500 NC, CE Elantech, Lakewood, NJ).

\section{Non-structural carbohydrates}


Sugar and starch concentrations were determined for samples from twelve of the measurement dates from 2011 and 2012 as one test for possible substrate limitation as a mechanism for observed partial acclimation. Extraction using hot ethanol and colorimetric determination of non-structural carbohydrates (NSC) followed Chow \& Landhäusser (2004). Finely ground root samples were mixed with $4.7 \mathrm{~mL}$ of $80 \%$ ethanol at $95^{\circ} \mathrm{C}$ for 10 minutes. Tests tubes were then centrifuged at $2500 \mathrm{rpm}$ for 3 minutes and the supernatant was decanted. The extraction and decanting process was repeated two more times and the composite decanted solution was brought to $14 \mathrm{ml}$ total volume and used for sugar analysis. The remaining residue was frozen for subsequent starch analysis.

The sugar extract was diluted 1:4 with deionized water, and $0.25 \mathrm{~mL}$ of the diluted sample solution was placed into $15 \mathrm{~mL}$ capacity $16 \mathrm{~mm}$ x $125 \mathrm{~mm}$ glass test tubes (14-933-1A, Thermo Fisher Scientific Inc.) in duplicate. A $100 \mu \mathrm{g} / \mathrm{mL}$ sample of glucose-fructose-galactose (GFG) standard solution was analyzed with every 30 root sample extracts for quality control. Then $0.5 \mathrm{~mL}$ of $2 \%$ phenol was added and mixed by vortex, and $1.25 \mathrm{~mL}(\geq 95 \%) \mathrm{H}_{2} \mathrm{SO}_{4}$ was added and mixed by vortex to each tube. Color was allowed to develop for 10 minutes in the dark initially, and then at room temperature in a water bath for 30 minutes.

The resulting colored solutions were placed in a $1.5 \mathrm{~mL}$ capacity semi-micro polystyrene cuvette (Z692298, Sigma-Aldrich) and absorbance was measured at $490 \mathrm{~nm}$ (Beckman Coulter DU 640 Spectrophotometer). Since concentrated $\mathrm{H}_{2} \mathrm{SO}_{4}$ hydrolyzes interfering substances (chlorophyll, pigments, lipids, phenolics, proteins, etc) and creates 
blue-purple compounds, a parallel sugar assay of similar protocol was used, but instead of $0.5 \mathrm{~mL} 2 \%$ phenol, $0.5 \mathrm{~mL}$ of deionized water was used to enable correction. Additionally, according to Chow \& Landhausser (2004), ethanol can interfere with absorbance readings at higher concentrations and give a reading that is $13 \%$ lower, so final sugar concentrations were corrected for the extract ethanol interference.

Starch was solubilized from the residue from the sugar extraction with $2.0 \mathrm{~mL}$ of $0.1 \mathrm{~N} \mathrm{NaOH}$ in a $50^{\circ} \mathrm{C}$ water bath, and then neutralized with $2.5 \mathrm{~mL}$ of $0.1 \mathrm{~N}$ acetic acid after 30 minutes. An enzyme solution was prepared from a mixture $\alpha$-amylase (SigmaAldrich, from Bacillus licheniformis) and amyloglucosidase (Sigma-Aldrich, from Aspergillus niger) to convert the starch to glucose. The enzyme digestion solution was prepared with $0.05 \mathrm{M} \mathrm{NaOAc}$ buffer, $\mathrm{pH} 5.1$, so that the final concentration of activity units were $2000 \mathrm{U} / \mathrm{mL}$ of $\alpha$-amylase and $10 \mathrm{U} / \mathrm{mL}$ of amyloglucosidase. An aliquot of $0.5 \mathrm{~mL}$ of the digestive enzyme solution was added to all test tubes. Additionally, a sample of $0.05 \mathrm{~g}$ of potato starch was analyzed with every group of 30 root samples for quality control. After the addition of the digestive enzyme solution, the test tubes were incubated in a $50^{\circ} \mathrm{C}$ water bath for 24 hours.

After the digestion, the tubes were centrifuged at $2500 \mathrm{rpm}$ for 3 minutes and an aliquot of the supernatant was pipetted to a 1:5 dilution with $0.05 \mathrm{NaOAc}$ for samples. The potato starch was diluted 1:100, due to higher starch concentration. To each solution, $2.0 \mathrm{~mL}$ of PGO-color reagent solution (Sigma) was added and $0.4 \mathrm{~mL}$ of $75 \%$ $\mathrm{H}_{2} \mathrm{SO}_{4}$ was rapidly added and mixed by vortex. After color developed in the dark at room temperature for 45 minutes, absorbance was read at $525 \mathrm{~nm}$. Due to interfering 
substances the $2.0 \mathrm{~mL}$ of PGO-color reagent solution was replaced with $2.0 \mathrm{~mL}$ of deionized water and absorbance read at $525 \mathrm{~nm}$ and final measurements were corrected.

\section{Application of Exogenous Sugars and the Uncoupling Agent}

The use of exogenous sugar (glucose) and an uncoupling agent (CCCP) to test for substrate limitation and adenylate control were conducted in May, July, and September 2013 using fine-root samples collected from all twelve experimental plots. The analyses were conducted at both ambient temperature and the reference temperature of $18{ }^{\circ} \mathrm{C}$. The method was modified from Drake et al. (2008). Fine roots $(<1 \mathrm{~mm}$ diameter) were obtained as described previously, with at least $8.0 \mathrm{~g}$ fresh weight of fine roots collected per plot. The sample was divided into four approximately equal subsamples. The subsamples were submerged in a buffer solution $\left(1 \mathrm{mM} \mathrm{CaCl}_{2}\right.$ buffered to $\mathrm{pH} 5.5$ with 2Morpholinoethanesulfonic acid, MES) for 5 minutes and randomly assigned to and submerged in one of four treatment solutions: control (buffer solution), glucose (buffer solution then $50 \mathrm{mM}$ glucose), uncoupler (buffer solution then $15 \mathrm{mM}$ carbonyl cyanide m-chlorophenylhydrazone, CCCP), and glucose + uncoupler (buffer solution then glucose + CCCP).

All subsamples remained in their respective solutions for 15 minutes, except the control that was removed from the buffer and placed in an absorbent tissue for 15 minutes. Excess moisture was then removed from the subsamples with a tissue and respiration rate was measured in the IRGA at ambient soil or reference temperature as described previously. All readings were finished within 60 minutes after roots were 
removed from the soil. After samples were removed from the IRGA, they were placed on ice and subsequently cleaned, dried and weighed in the lab to obtain specific root respiration rates as previously described.

\section{Soil Nitrogen Mineralization}

The availability of $\mathrm{N}$ in the soil can affect root-system activity, therefore, net $\mathrm{N}$ mineralization was determined using the buried bag technique (Eno 1960). There were three incubations per plot every 4-5 weeks from May to October 2011, March to October in 2012, and May to October in 2013. Three randomly located pairs of $5 \mathrm{~cm}$ diameter by $10 \mathrm{~cm}$ deep soil cores were collected from each plot. One of the cores was taken back to the laboratory and a $25 \mathrm{~g}$ subsample was subsequently extracted with $50 \mathrm{~mL}$ of $2 \mathrm{M} \mathrm{KCl}$ for determination of initial soil extractable $\mathrm{NO}_{3}{ }^{-}$and $\mathrm{NH}_{4}{ }^{+}$contents. The other core was placed in situ inside a polyethylene bag, and replaced in the original hole until being removed at the beginning of the next sample period. A $25 \mathrm{~g}$ subsample was then obtained from these incubated cores and extracted with $50 \mathrm{~mL}$ of $2 \mathrm{M} \mathrm{KCl}$ to assess final soil $\mathrm{NO}_{3}{ }^{-}$and $\mathrm{NH}_{4}{ }^{+}$contents. Net $\mathrm{N}$ mineralization was calculated as the difference in $\mathrm{NO}_{3}{ }^{-}-\mathrm{N}$ plus $\mathrm{NH}_{4}{ }^{+}-\mathrm{N}$ between final and initial cores of a pair.

\section{Statistical Analyses}

Two-factor (heat,water) repeated measures analysis of variance (ANOVA) was used to test for treatment effects on specific fine-root respiration $\left(\mathrm{nmol} \mathrm{CO}_{2} \mathrm{~g}^{-1} \mathrm{~s}^{-1}\right)$ and fine root $\mathrm{N}$ concentration using data from 2010 through 2013, with respiration for each sample date as the repeated measure. Two-factor repeated measures ANOVA also was 
used to test differences in treatment effects on fine-root sugar $\left(\mathrm{mg} \mathrm{g}^{-1}\right)$, starch $\left(\mathrm{mg} \mathrm{g}^{-1}\right)$,

and NSC $\left(\mathrm{mg} \mathrm{g}^{-1}\right)$ across dates. Data were log-transformed to meet assumptions of homogeneity of variance for root starch. A four-factor (heat, water, glucose, uncoupler) repeated measures ANOVA with glucose and uncoupler nested within experimental treatments plots was used to test differences among treatments in the response of fineroot respiration to exogenous sugar and $\mathrm{CCCP}$, with repeated dates. Treatment effects on seasonal net $\mathrm{N}$ mineralization were analyzed using a two-factor (heat, water) repeated measures ANOVA, with seasonal net $\mathrm{N}$ mineralization $\left(\mu \mathrm{g} \mathrm{N} \mathrm{g} \mathrm{soil}{ }^{-1}\right)$ for each year $(2011$ - 2013) as the repeated measure. Data from the portion of each year when treatments were active was used in this analysis.

\section{Results}

The warming treatment successfully increased soil temperatures into the desired range $\left(4-5^{\circ} \mathrm{C}\right)$ (Table 2.1) during the portion of each year when the full heat treatment was applied. Soil warming was similar at 2,5 and $10 \mathrm{~cm}$, as well as directly beneath and midway between rows of heat lamps. Soil moisture was lowest for the heat treatment and was generally similar for the heat + water and control treatments (Table 2.1), achieving the desired experimental conditions. Soil warming also resulted in greater net $\mathrm{N}$ mineralization for treatments with heat, while water addition had no effect (Table 2.1). The impact of soil warming on net $\mathrm{N}$ mineralization declined over time, from a $68 \%$ enhancement in treatments with heat (heat and heat + water) in 2011 to only a $28 \%$ enhancement with soil warming in 2013. 


\section{Acclimation of Fine-root Respiration}

From 2010 through 2013 average fine-root respiration measured at the reference temperature of $18{ }^{\circ} \mathrm{C}$ was consistently lower on the heated plots (heat, heat + water) than the non-heated plots (control, water) (Figure 2.1, Table 2.2). The data presented are average across all sample dates. At ambient field temperature, average specific-fine root respiration rates were significantly higher on the heated plots than the non-heated plots (Figure 2.1, Table 2.2). The effect of soil warming varied among sample dates; during dry periods there were even occasional dates where respiration rates for the heated plots at ambient temperature were lower than rates for the control treatment. This effect was a major contributor to the significant heat $\mathrm{x}$ date interaction at ambient temperature and smaller heat responses observed in 2011 and 2012 than in 2010 and 2013 (Figure 2.1). There was a slight indication $(P=0.092)$ that water addition increased fine-root specific respiration rates at ambient temperature. This effect was much more apparent in years with prolonged dry periods (2011 and 2012) than in moist years (2010 and 2013), leading to a significant water by date interaction (Table 2.2). Despite observed effects of treatments on fine-root respiration, fine-root $\mathrm{N}$ concentrations were not altered by the $3+$ years of treatments (Table 2.1).

\section{Non-structural Carbohydrates}

Fine-root sugar concentrations were not affected by either the heat or water treatments (Figure 2.2, Table 2.3), but starch concentrations of the fine-roots were significantly lower for the heated treatments $(P=0.014)$. Total NSC (sugar + starch) was 
not affected by the heat or water treatments (Table 2.3). There were very low values of starch during most of the season with values increasing nearly 3-fold in the fall; May to August starch values averaged $2.4 \mathrm{mg} \mathrm{g}^{-1}$, and increased to an average of $9.6 \mathrm{mg} \mathrm{g}^{-1}$ for September and October.

\section{Effects of Exogenous Glucose and Respiratory Uncoupler}

Glucose addition did not alter fine-root specific respiration rate for any experimental treatment (Figure 2.3, Table 2.4). The uncoupler (CCCP) increased fineroot respiration regardless of experimental treatment (Figure 2.3, Table 2.4). There were no interactions between glucose and CCCP additions. The relative response to CCCP was 1.4 times greater for heated treatments than for those without soil warming (Figure 2.4, $P=0.098$ for heat $\mathrm{x}$ CCCP interaction in Table 2.4). There were no significant interactions with sample date for glucose, CCCP, or their interaction (Table 2.4).

\section{Discussion}

Reduced fine-root respiration rates at the $18{ }^{\circ} \mathrm{C}$ reference temperature (Figure 2.1) indicate that partial thermal acclimation occurred consistently in sugar maple roots during the $3+$ years of soil warming in the SMART experiment. Partial acclimation is that which is a reduction in respiration on the heated treatments versus the non-heated treatments when examined at the reference temperature of $18{ }^{\circ} \mathrm{C}$. This is in relation to full acclimation or homeostasis at which time there would be no difference in respiration in the heated treatments versus the non-heated treatments even though there would be a temperature differential of $4-5^{\circ} \mathrm{C}$ between the two treatments. This is not the case yet 
(Figure 2.2, top plate), but there still some degree of partial acclimation occurring (Figure 2.2). We have previously shown that dry soil created by soil warming can contribute to lower root respiration rates for the heated treatments (Jarvi \& Burton 2013), but the consistently lower specific respiration rates during both wet and dry periods throughout the experiment indicate that thermal acclimation is occurring for respiration of fine roots from the heat and heat + water treatments.

Evidence of acclimation of fine-root respiration is also apparent for respiration measured at ambient field temperature. Fine-root respiration is higher on heated plots than non-heated plots (Figure 2.1), due to a higher ambient field temperature for the heated plots: $18.6{ }^{\circ} \mathrm{C}$ on average during the full warming periods of the experiment, versus $14.2{ }^{\circ} \mathrm{C}$ for the non-heated plots. However, the degree of respiratory enhancement was considerably less than would be expected for the average increase of $4.4^{\circ} \mathrm{C}$, indicating that some amount of down-regulation was occurring. Seasonal observations on the control plots of the SMART experiment indicate a $\mathrm{Q}_{10}$ of 2.7 for fine root respiration (Jarvi \& Burton 2013). This would result in an expected 55\% increase in root respiration for a temperature increase of $4.4{ }^{\circ} \mathrm{C}$, which is much greater than the observed increases in root respiration of $14 \%$ and $26 \%$ for the heat and heat + water plots, respectively, over the duration of the study.

Several mechanisms could exist to contribute to this apparent thermal acclimation including altered enzymatic capacity, substrate limitation, and adenylate control. We found no evidence for enzyme limitation, as fine-root $\mathrm{N}$ concentration was not affected by heat or water treatments over the $3+$ years of measurements (Table 2.1). We had 
hypothesized that longer-term responses of fine roots to warmer soil could include the construction of new fine roots with lower enzyme concentrations, as indicated by lower tissue $\mathrm{N}$ concentration. Greater activity due to warmer temperatures in heated treatments would counteract the effects of lower enzyme concentrations, enabling sufficient metabolic activity to still occur under field conditions. Adjustment of tissue $\mathrm{N}$ in response to temperature (Lee et al. 2005, Tjoelker et al. 2008) has been observed for foliage, and construction of tissues with lower $\mathrm{N}$ concentration in warmer environments has been observed in experimentally warmed seedlings (Tjoelker et al. 1999). However, we found no evidence of such adjustments in enzymatic capacity occurring for the fine roots of the mature trees in our experiment, as fine-root $\mathrm{N}$ concentrations were not affected by either the heat or water treatments (Table 2.1). We previously reported this response through the 2011 growing season, but given the fairly long lifespan of sugar maple roots in the top portion of the soil (turnover of $0.50-0.68$ year $^{-1}$ ) in the Lake States (Hendrick and Pregitzer 1992, Burton et al. 2000, Fahey et al. 2012), such an adjustment remained a possibility at that time, as many of the fine roots had presumably not been yet been replaced through the fall of 2011. Adjustment of tissue $\mathrm{N}$ as a means of temperature acclimation has been postulated to be most likely for new tissue produced in the altered environment (Loveys et al. 2003). By 2013, it is likely that nearly all of the surface fine roots had been initiated well after treatments began in 2010, and no change in $\mathrm{N}$ concentration had occurred.

Substrate limitation could occur if carbohydrate supply to the roots was not sufficient to fully support potential respiration. We found no evidence that substrate 
limitation was occurring for these trees, based on additions of exogenous sugar (Figure 2.3). Covey-Crump et al. (2002) found that exogenous glucose increased fine-root respiration of hydroponically grown Plantago species, and Drake et al. (2008) found that exogenous glucose increased root respiration in a loblolly pine (Pinus taeda L.) plantation. The mature sugar maple trees evidently allocated sufficient photosynthate belowground to ensure that fine-roots were not limited by substrate in conjunction with the amount of work that these roots needed to conduct, even in elevated soil temperature.

The NSC analysis also suggest that substrate availability was not limiting respiration for the fine-roots $(<1 \mathrm{~mm})$ of sugar maple. Total NSC content in the fine-roots was dominated by sugar and neither total NSC nor sugar content were affected by the heat or water treatments. The decrease in starch for the heated plots represented a $15 \%$ decrease on the heat only plots, and a $20 \%$ decrease on the heat + water plots, but fineroots are not primary storage tissues and starch comprised only $\sim 0.4 \%$ of the total dry weight of fine-roots of sugar maple. It is possible that greater respiration in heated treatments caused a higher proportion of allocated sugar to be utilized, leaving less available for conversion to starch for temporary storage.

In contrast to substrate limitation and enzyme capacity, our results do show support for adenylate control as a mechanism contributing the observed partial thermal acclimation of fine root respiration. Adenylate control can occur if the ATP produced during respiration exceeded the ATP needed to support work being conducted by the root tissue, such as ion uptake, assimilation and transport (Atkin et al. 2000a). When this occurs, excess ATP is not converted back to ADP. The CCCP allows respiration $\left(\mathrm{O}_{2}\right.$ 
fixation and $\mathrm{CO}_{2}$ production) to occur without ATP production. This results in high ADP concentrations, effectively removing the signal in the electron transport chain that ATP is not being fully used and ADP concentrations are low, thereby eliminating reductions in respiration caused by high ATP:ADP ratios or low ADP concentration (Atkin et al. 2009). Treatment of root samples with the CCCP increased respiration for roots from all treatments (Figure 2.3). This suggests that during the active growing season, root respiration is always down-regulated to some degree. The roots have the capacity to produce ATP in excess of that needed to perform work associated with nutrient uptake and assimilation, growth, and other cell processes. This conceivably could allow fine roots to respond to pulses in nutrient availability driven by variations in soil moisture and temperature. As such, it may be a reason that we do not observe evidence of acclimation under ambient conditions in response to variations in soil temperature throughout the growing season (Burton \& Pregitzer 2003, Jarvi \& Burton 2013); as periods of high temperature and soil moisture would correspond to pulses of nutrient availability and thus the potential for high rates of fine-root work.

The uncoupler increased respiration more for the heated treatments than for those without soil warming (1.4 times more, Figure 2.4). This suggests that the fine-root specific respiration in warmed soil was constrained by adenylate control to a greater degree than in unheated soil. This could result from either: 1) internal signaling mechanisms that limit luxury nutrient uptake; or 2) increases in soil nutrient availability caused by warming being less than the increase in potential root system metabolic activity. Tree nutrient requirements at the site should not have increased greatly because 
fine-root biomass (Jarvi \& Burton 2013), bole growth, canopy leaf area, and litter production (Jarvi unpublished) have not increased in response to the experimental treatments. Additionally, nutrient availability ( soil N) was not greatly increased in 2013 (Table 2.1), when the uncoupler tests were conducted. For the 2013 growing season, net $\mathrm{N}$ mineralization for the heat and heat + water treatments was $28 \%$ greater than that for the control and water treatments. This suggests that greatly enhanced root metabolic activity to support $\mathrm{N}$ uptake was not possible, and thus is consistent with adenylate control being responsible for a portion of the acclimation observed.

Covey-Crump et al. (2002) found that the respiratory uncoupler and glucose additions both increased root respiration for two Plantago species at moderate temperatures, with adenylates more limiting than substrate supply. Drake et al. (2008) also found a stimulation of root respiration in response to the addition of CCCP for mature Pinus teada L. and concluded that instantaneous root respiration is controlled, at least partially, by ATP utilization in addition to substrate availability. Therefore, these studies indicate that root respiration rates in these systems are partially constrained by the amount of work that can be done or is needed to be accomplished.

The potential need for additional fine-root respiration to support greater root system work in warmer soil can be assessed by examining the components of root respiration (growth, ion uptake, and maintenance) and considering separately their potential changes in response to the warming treatments. The proportion of total root respiration that can be attributed to growth respiration can vary considerably among species (Poorter et al. 1991). For sugar maple fine roots in mature forests, it has been 
estimated to be $1.1 \mathrm{nmol} \mathrm{g}^{-1} \mathrm{~s}^{-1}$ during the most active period of root growth in early summer, and less during other portions of the growing season (Burton et al. 1996). This is a relatively small proportion of total root respiration rates we have found in this study. Additionally, the surface fine-root biomass did not change in response to experimental treatments at this location (Jarvi \& Burton 2013). Unless fine-root turnover was greatly altered, it is very unlikely that the demand for ATP to support fine-root growth respiration was greatly changed by the treatments.

Another mechanism by which the root systems of trees can respond to changes in their growing environment would be to alter fine-root biomass. Zhou el al. (2011) found that the trees growing at the Harvard Forest soil warming experiment did not alter fineroot N, but did decrease fine-root biomass. This allowed ecosystem level fine-root respiration to decrease overall. This result was found after 7 years of soil warming (Melillo et al. 2011, Zhou et al. 2011).

Respiration associated with ion uptake can account for a majority of total root respiration (Poorter et al. 1991). Since fine-root $\mathrm{N}$ concentration (Table 2.1) and biomass and leaf litterfall (Jarvi unpublished) also have not changed, a significantly greater demand for nutrients to construct these nutrient-rich tissues should not exist. Thus a large increase in root respiration to support ion uptake also should not exist. However, soil $\mathrm{N}$ mineralization has increased at this location in the heated treatments (Table 2.1) so ion uptake root respiration could theoretically increase somewhat due to increases in uptake and storage of $\mathrm{N}$ in excess of annual requirements. Maintenance root respiration can be very small (5-10\%) in active root systems (Van Der Werf et al. 1988, Scheuwater 
et al. 1998). Proteins associated with respiration are temperature sensitive (Atkin et al. 2000a) and can account for 60-80\% of maintenance respiration (Bouma et al. 1994, Bouma et al. 1996) which could cause maintenance respiration to increase with temperature (Amthor 1984, Johnson 1990). Therefore, due to increased soil temperatures on the heated treatments, there could be an increase in maintenance root respiration in the experiment. Overall, there does not appear to be a need for large increases in fine-root respiration in the heated treatments, but potential slight increases in ion uptake and maintenance root respiration could account for the observed levels of increase in root respiration on the heated treatments (heat and heat + water).

\section{Conclusion}

Overall, our data indicate that fine-root respiration is down-regulated, at least partially through adenylate control, to match the work required of the root system for needed processes such as nutrient uptake and assimilation. This has helped the ecosystem limit $\mathrm{C}$ return to the atmosphere, reducing possible autotrophic contributions to a positive feedback to atmospheric $\mathrm{CO}_{2}$ and climatic warming. From a carbon balance standpoint, such a mechanism will also help maintain the proportion of photosynthate allocated to production. In a warmer future world, this, in combination with longer growing season and potentially greater annual $\mathrm{C}$ assimilation, could allow trees to utilize more $\mathrm{C}$ for production of leaf area, diameter growth, or defensive compounds (Kerhoulas \& Kane 2012, Lacointe 2000). Although the mechanism may be different, it appears root system activity in forests subjected to experimental soil warming remains aligned with the work that must be completed to support uptake of water and nutrients. 
Our data suggests that models used to predict the impacts of climate change should not allow tissue respiration to increase exponentially with temperature (Smith \& Dukes 2013). Instead it appears C allocation to root system activity should be related to the work being performed by roots, which is not necessarily expected to increase greatly in a warmer world. 


\section{Tables \& Figures}

Table 2.1. Average soil temperature, soil moisture, fine-root $\mathrm{N}$ concentration, and surface soil $(0-10 \mathrm{~cm})$ net $\mathrm{N}$ mineralization for the four experimental treatments. Standard error of the annual mean for the three plots per treatment is presented in parentheses. Net $\mathrm{N}$ mineralization was significantly greater for heated treatments across years $(P=0.037)$. The effects of water addition and the heat $\mathrm{x}$ water interaction on $\mathrm{N}$ mineralization were not significant. Fine root $\mathrm{N}$ was not altered by the treatments.

\begin{tabular}{|c|c|c|c|c|c|}
\hline & Year & Control & Heat & Water & Heat + water \\
\hline \multirow[t]{4}{*}{ Soil temperature $^{1}$} & 2010 & $8.3(0.1)$ & $12.5(0.1)$ & $8.4(0.1)$ & $12.8(0.3)$ \\
\hline & 2011 & $14.9(0.3)$ & $20.2(0.2)$ & $15.0(0.4)$ & $19.6(0.4)$ \\
\hline & 2012 & $15.0(0.2)$ & $19.6(0.2)$ & $15.2(0.4)$ & $19.8(0.4)$ \\
\hline & 2013 & $14.9(0.1)$ & $18.1(0.2)$ & $15.0(0.3)$ & $18.6(0.2)$ \\
\hline \multirow[t]{4}{*}{ Soil moisture $^{1}$} & 2010 & $0.296(0.016)$ & $0.278(0.015)$ & $0.321(0.029)$ & $0.328(0.032)$ \\
\hline & 2011 & $0.212(0.005)$ & $0.173(0.007)$ & $0.250(0.023)$ & $0.223(0.015)$ \\
\hline & 2012 & $0.245(0.010)$ & $0.209(0.015)$ & $0.271(0.017)$ & $0.237(0.013)$ \\
\hline & 2013 & $0.260(0.028)$ & $0.229(0.015)$ & $0.292(0.027)$ & $0.267(0.17)$ \\
\hline \multirow[t]{4}{*}{ Fine-root $\mathrm{N}$} & 2010 & $11.2(0.4)$ & $10.7(0.6)$ & $10.9(0.7)$ & $10.7(0.3)$ \\
\hline & 2011 & $11.9(0.5)$ & $11.9(0.6)$ & $11.7(0.7)$ & $11.8(0.6)$ \\
\hline & 2012 & $10.8(0.5)$ & $10.4(0.4)$ & $11.1(0.7)$ & $10.4(0.9)$ \\
\hline & 2013 & $10.7(0.3)$ & $10.4(0.5)$ & $10.3(0.4)$ & $9.9(0.7)$ \\
\hline \multirow[t]{3}{*}{$\mathrm{N}$ mineralization } & 2011 & $0.409(0.026)$ & $0.713(0.214)$ & $0.373(0.084)$ & $0.598(0.088)$ \\
\hline & 2012 & $0.482(0.063)$ & $0.795(0.102)$ & $0.559(0.033)$ & $0.633(0.072)$ \\
\hline & 2013 & $0.334(0.031)$ & $0.533(0.062)$ & $0.426(0.041)$ & $0.438(0.084)$ \\
\hline
\end{tabular}

${ }^{1}$ Values are the mean of all sensors for a given treatment during the period of full warming (18 Sep to 16 Nov in 2010; 3 May to 15 Oct in 2011; 17 Apr to 24 Sep in 2012; and 13 May to 24 Sep in 2013). Temperature differentials were 1 to $2{ }^{\circ} \mathrm{C}$ less during ramp up and ramp down periods before and after these dates. Temperature and moisture sensors were located at depths of 2,5 and $10 \mathrm{~cm}$ and locations beneath and between heater lines. 
Table 2.2. Repeated measures ANOVA table for fine-root respiration $(<1 \mathrm{~mm}$ diameter) for 27 dates from the 2010 through 2013 growing seasons at ambient soil temperature for the sample date and a common reference temperature of $18{ }^{\circ} \mathrm{C}$.

\begin{tabular}{|c|c|c|c|c|c|c|c|}
\hline \multirow[t]{2}{*}{ Source } & \multirow[t]{2}{*}{ df } & \multicolumn{3}{|c|}{ Ambient } & \multicolumn{3}{|c|}{ Reference } \\
\hline & & $\begin{array}{l}\text { Mean } \\
\text { Square }\end{array}$ & $\begin{array}{l}F \\
\text { ratio }\end{array}$ & $P$ & $\begin{array}{l}\text { Mean } \\
\text { Square }\end{array}$ & $\begin{array}{l}F \\
\text { ratio }\end{array}$ & $P$ \\
\hline \multicolumn{8}{|c|}{$\begin{array}{l}\text { Between } \\
\text { subjects }\end{array}$} \\
\hline Heat & 1 & 17.57 & 12.90 & 0.007 & 72.54 & 40.36 & $<0.001$ \\
\hline Water & 1 & 5.01 & 3.68 & 0.092 & 0.82 & 0.46 & 0.519 \\
\hline $\begin{array}{l}\text { Heat } x \\
\text { water }\end{array}$ & 1 & 0.32 & 0.24 & 0.640 & 0.97 & 0.54 & 0.484 \\
\hline Error & 8 & 1.36 & & & 1.80 & & \\
\hline \multicolumn{8}{|l|}{$\begin{array}{l}\text { Within } \\
\text { subjects }\end{array}$} \\
\hline $\begin{array}{l}\text { Sample } \\
\text { date }\end{array}$ & 26 & 14.00 & 16.58 & $<0.001$ & 14.94 & 9.64 & $<0.001$ \\
\hline $\begin{array}{l}\text { Heat } \mathrm{x} \\
\text { date }\end{array}$ & 26 & 1.83 & 2.16 & 0.002 & 1.18 & 0.76 & 0.794 \\
\hline $\begin{array}{l}\text { Water } \mathrm{x} \\
\text { date }\end{array}$ & 26 & 1.40 & 1.65 & 0.029 & 1.84 & 1.19 & 0.249 \\
\hline $\begin{array}{l}\text { Heat } x \\
\text { water } x \\
\text { date }\end{array}$ & 26 & 0.38 & 0.45 & 0.991 & 1.30 & 0.84 & 0.697 \\
\hline Error & 208 & 0.84 & & & 1.55 & & \\
\hline
\end{tabular}


Table 2.3. Repeated measures ANOVA table for sugar $\left(\mathrm{mg} \mathrm{g}^{-1}\right)$, starch $\left(\mathrm{mg} \mathrm{g}^{-1}\right)$, and total non-structural carbohydrates (NSC, $\mathrm{mg} \mathrm{g}^{-1}$ ). Starch values were measured as glucose equivalents. Starch values were multiplied by 10 and $\log$ transformed prior to analysis to satisfy assumptions of homogeneity of variance.

\begin{tabular}{|c|c|c|c|c|c|c|c|c|c|c|}
\hline \multirow[t]{2}{*}{ Source } & \multirow[t]{2}{*}{$\mathrm{df}$} & \multicolumn{3}{|c|}{ Sugar $\left(\mathrm{mg} \mathrm{g}^{-1}\right)$} & \multicolumn{3}{|c|}{ Starch $\left(\log \left(\mathrm{mg} \mathrm{g}^{-1} * 10\right)\right)$} & \multicolumn{3}{|c|}{$\mathrm{TNC}\left(\mathrm{mg} \mathrm{g}^{-1}\right)$} \\
\hline & & $\begin{array}{l}\text { Mean } \\
\text { square }\end{array}$ & $\begin{array}{l}F- \\
\text { ratio }\end{array}$ & $P$ & $\begin{array}{l}\text { Mean } \\
\text { square }\end{array}$ & $\begin{array}{l}F- \\
\text { ratio }\end{array}$ & $P$ & $\begin{array}{l}\text { Mean } \\
\text { square }\end{array}$ & $\begin{array}{l}F- \\
\text { ratio }\end{array}$ & $P$ \\
\hline \multicolumn{11}{|l|}{$\begin{array}{l}\text { Betwee } \\
\text { n } \\
\text { subjects }\end{array}$} \\
\hline Heat & 1 & 1.91 & 0.02 & 0.893 & 1.31 & 9.72 & 0.014 & 20.56 & 0.27 & 0.615 \\
\hline Water & 1 & 7.80 & 0.08 & 0.786 & 0.02 & 0.17 & 0.689 & 6.36 & 0.08 & 0.779 \\
\hline $\begin{array}{l}\text { Heat } x \\
\text { water }\end{array}$ & 1 & 47.54 & 0.48 & 0.509 & 0.06 & 0.42 & 0.537 & 74.34 & 0.99 & 0.349 \\
\hline Error & 8 & 99.26 & & & 0.13 & & & 75.23 & & \\
\hline \multicolumn{11}{|l|}{$\begin{array}{l}\text { Within } \\
\text { subjects }\end{array}$} \\
\hline $\begin{array}{l}\text { Sample } \\
\text { date }\end{array}$ & 11 & 245.43 & 4.83 & $<0.001$ & 1.98 & 32.57 & $<0.001$ & 569.20 & 8.33 & $<0.001$ \\
\hline $\begin{array}{l}\text { Heat } x \\
\text { date }\end{array}$ & 11 & 24.42 & 0.48 & 0.911 & 0.09 & 1.45 & 0.167 & 56.90 & 0.83 & 0.608 \\
\hline $\begin{array}{l}\text { Water } \mathrm{x} \\
\text { date }\end{array}$ & 11 & 38.26 & 0.75 & 0.685 & 0.05 & 0.76 & 0.677 & 36.50 & 0.53 & 0.875 \\
\hline $\begin{array}{l}\text { Heat } x \\
\text { water } x \\
\text { date }\end{array}$ & 11 & 65.48 & 1.29 & 0.244 & 0.05 & 0.90 & 0.543 & 61.90 & 0.91 & 0.538 \\
\hline Error & 88 & 50.81 & & & 0.06 & & & 68.30 & & \\
\hline
\end{tabular}


Table 2.4. Repeated measures ANOVA table for fine-root respiration with the effects of exogenous sugar (glucose) and/or the respiratory uncoupling agent (CCCP) at both ambient soil temperature and common reference temperature of $18^{\circ} \mathrm{C}$.

\begin{tabular}{|c|c|c|c|c|c|c|c|}
\hline \multirow[t]{2}{*}{ Source } & d.f. & Ambient & & & Reference & & \\
\hline & & Mean Square & $F$ ratio & $P$ & Mean Square & $F$ ratio & $P$ \\
\hline \multicolumn{8}{|l|}{ Between subjects } \\
\hline Heat & 1 & 50.07 & 35.99 & $<0.001$ & 9.48 & 2.63 & 0.143 \\
\hline Water & 1 & 0.01 & 0.01 & 0.942 & 4.48 & 1.24 & 0.297 \\
\hline Heat $\mathrm{x}$ water & 1 & 0.29 & 0.21 & 0.659 & 0.03 & 0.01 & 0.928 \\
\hline Error & 8 & 1.39 & & & 3.60 & & \\
\hline \multicolumn{8}{|l|}{ Within subjects } \\
\hline Glucose & 1 & 0.004 & 0.01 & 0.938 & 2.64 & 1.39 & 0.241 \\
\hline Uncoupler & 1 & 14.595 & 22.04 & $<0.001$ & 15.69 & 8.26 & 0.005 \\
\hline Date & 2 & 12.518 & 18.91 & $<0.001$ & 0.83 & 0.44 & 0.646 \\
\hline Heat $x$ glucose & 1 & 0.214 & 0.32 & 0.571 & 4.84 & 2.55 & 0.114 \\
\hline Water x glucose & 1 & 0.096 & 0.146 & 0.704 & 0.28 & 0.15 & 0.703 \\
\hline Heat x uncoupler & 1 & 1.847 & 2.79 & $0.0984 *$ & 0.55 & 0.29 & 0.591 \\
\hline Water x uncoupler & 1 & 1.356 & 2.05 & 0.156 & 1.25 & 0.66 & 0.420 \\
\hline Glucose x uncoupler & 1 & 1.256 & 1.90 & 0.172 & 0.41 & 0.21 & 0.644 \\
\hline Heat $\mathrm{x}$ date & 2 & 2.990 & 4.52 & 0.014 & 0.83 & 0.44 & 0.649 \\
\hline Water $\mathrm{x}$ date & 2 & 1.430 & 2.16 & 0.121 & 4.22 & 2.22 & 0.114 \\
\hline Glucose $\mathrm{x}$ date & 2 & 1.101 & 1.66 & 0.196 & 2.96 & 1.56 & 0.217 \\
\hline Uncoupler $\mathrm{x}$ date & 2 & 0.093 & 0.14 & 0.870 & 2.69 & 1.42 & 0.248 \\
\hline Heat $x$ water $x$ glucose & 1 & 0.074 & 0.11 & 0.739 & 0.59 & 0.31 & 0.578 \\
\hline Heat $\mathrm{x}$ water $\mathrm{x}$ uncoupler & 1 & 2.329 & 3.52 & $0.0641^{*}$ & 0.28 & 0.15 & 0.704 \\
\hline Heat $x$ glucose $\mathrm{x}$ uncoupler & 1 & 0.075 & 0.11 & 0.737 & 1.06 & 0.56 & 0.456 \\
\hline Water $\mathrm{x}$ glucose $\mathrm{x}$ uncoupler & 1 & 0.004 & 0.01 & 0.940 & 0.27 & 0.14 & 0.710 \\
\hline Heat $\mathrm{x}$ water $\mathrm{x}$ date & 2 & 0.212 & 0.32 & 0.727 & 3.73 & 1.96 & 0.146 \\
\hline Heat $x$ glucose $x$ date & 2 & 0.608 & 0.92 & 0.403 & 4.31 & 2.27 & 0.110 \\
\hline Water $\mathrm{x}$ glucose $\mathrm{x}$ date & 2 & 0.743 & 1.12 & 0.330 & 0.41 & 0.21 & 0.808 \\
\hline Heat $\mathrm{x}$ uncoupler $\mathrm{x}$ date & 2 & 0.109 & 0.16 & 0.849 & 0.48 & 0.25 & 0.777 \\
\hline Water $\mathrm{x}$ uncoupler $\mathrm{x}$ date & 2 & 0.500 & 0.75 & 0.473 & 2.10 & 1.11 & 0.335 \\
\hline Glucose $\mathrm{x}$ uncoupler $\mathrm{x}$ date & 2 & 0.083 & 0.13 & 0.883 & 0.51 & 0.27 & 0.765 \\
\hline Heat $x$ water $x$ glucose $x$ uncoupler & 1 & 0.015 & 0.02 & 0.879 & 2.59 & 1.36 & 0.246 \\
\hline Heat $\mathrm{x}$ water $\mathrm{x}$ glucose $\mathrm{x}$ date & 2 & 0.421 & 0.64 & 0.532 & 0.13 & 0.66 & 0.519 \\
\hline Heat $\mathrm{x}$ water $\mathrm{x}$ uncoupler $\mathrm{x}$ date & 2 & 0.124 & 0.19 & 0.829 & 0.75 & 0.39 & 0.676 \\
\hline Heat $x$ glucose $x$ uncoupler $x$ date & 2 & 0.135 & 0.20 & 0.816 & 2.04 & 0.11 & 0.346 \\
\hline Water $\mathrm{x}$ glucose $\mathrm{x}$ uncoupler $\mathrm{x}$ date & 2 & 0.604 & 0.91 & 0.406 & 0.02 & 0.01 & 0.991 \\
\hline Heat $\mathrm{x}$ water $\mathrm{x}$ glucose $\mathrm{x}$ uncoupler $\mathrm{x}$ date & 2 & 0.098 & 0.15 & 0.863 & 1.77 & 0.93 & 0.397 \\
\hline Error & 88 & 0.662 & & & 1.90 & & \\
\hline
\end{tabular}



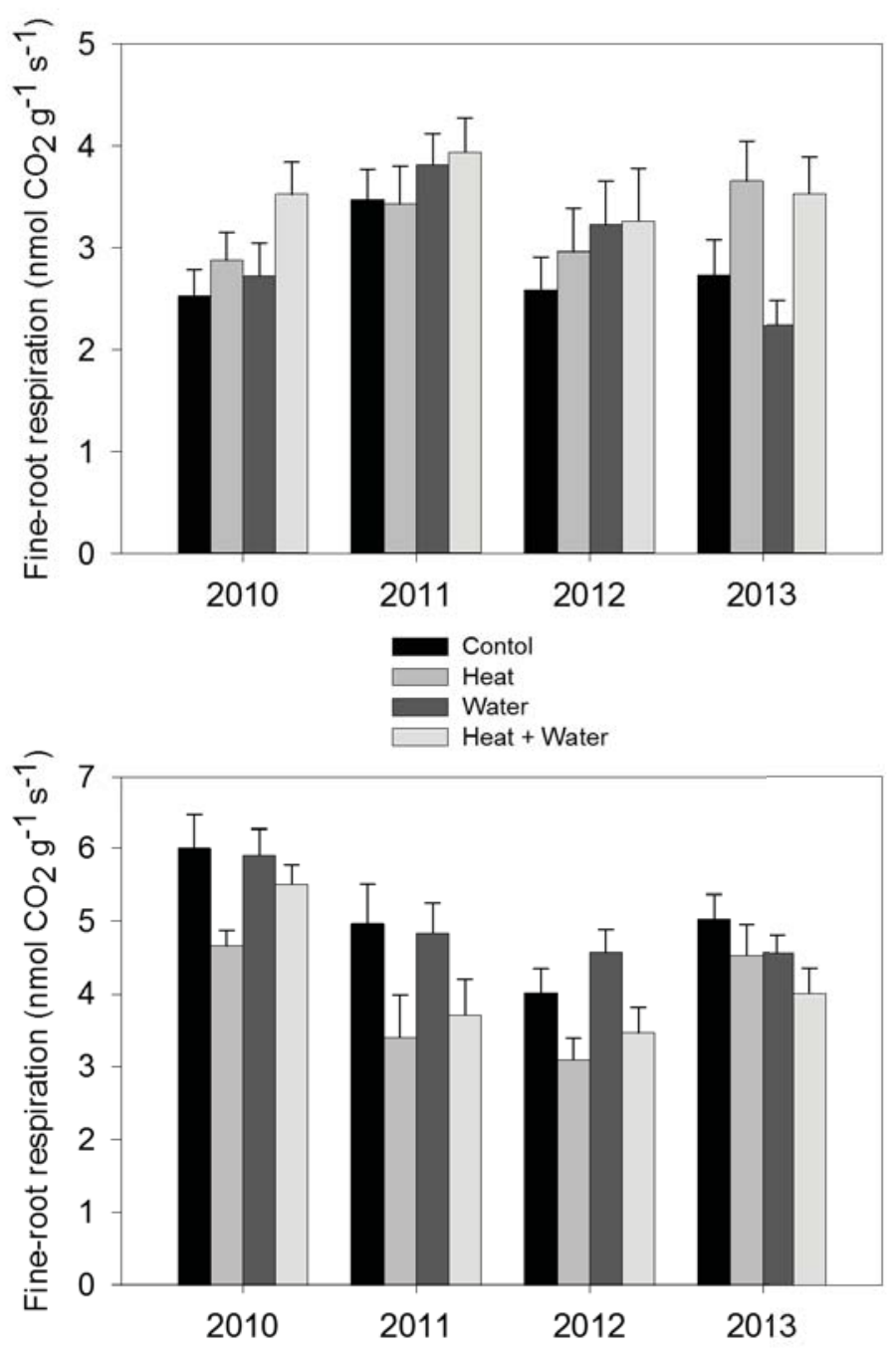

Figure 2.1. Fine-root respiration $\left(<1 \mathrm{~mm}\right.$ diameter) $\left(\mathrm{nmol} \mathrm{CO}_{2} \mathrm{~g}^{-1} \mathrm{~s}^{-1}\right)$ at ambient (top plate) and $18{ }^{\circ} \mathrm{C}$ reference soil temperature (bottom plate) across four soil treatments and 27 samples dates from 2010-2013 including: 20 September 2010, 27 September 2010, 13 October 2010, 29 October 2010, 12 November 2010, 13 May 2011, 31 May 2011, 24 June 2011, 15 July 2011, 1 August 2011, 23 August 2011, 12 September 2011, 25 March 2012, 26 April 2012, 16 May 2012, 27 June 2012, 18 July 2012, 31 August 2012, 29 September 2012, 24 October 2012, 14 May 2013, 29 May 2013, 11 June 2013, 2 July 2013, 30 July 2013, 26 August 2013, and 21 September 2013. Error bars represent standard error of the mean. 


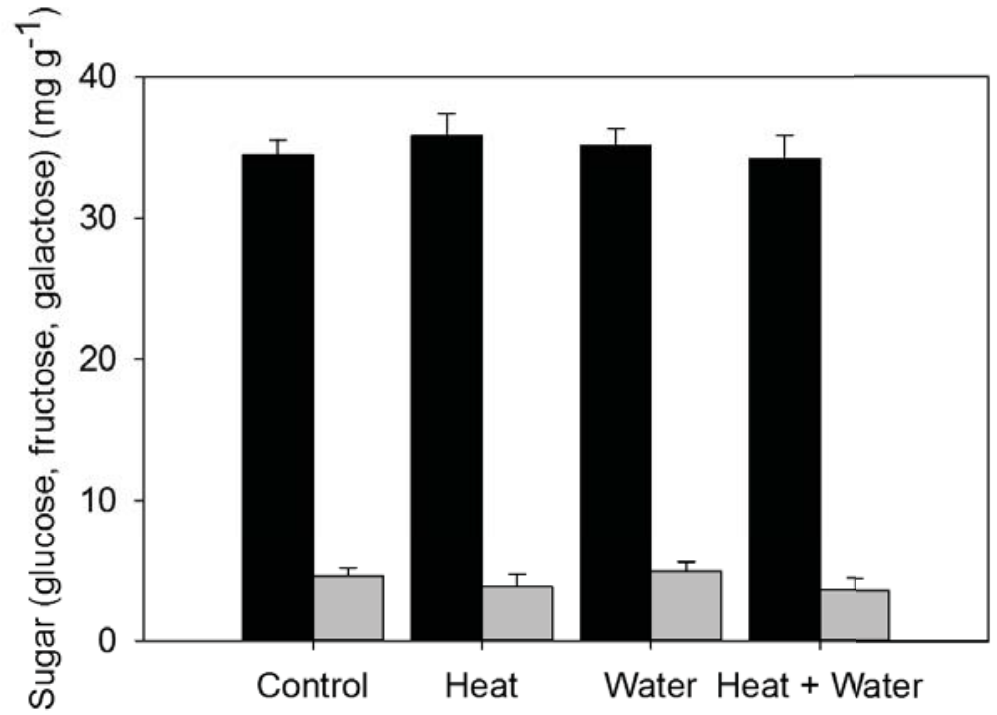

Figure 2.2. Average fine-root non-structural sugar (black bars, glucose, fructose, galactose, $\mathrm{mg} \mathrm{g}^{-1}$ ) starch measured as glucose equivalents (gray bars, $\mathrm{mg} \mathrm{g}^{-1}$ ) concentrations across all dates. Error bars represent standard error of the mean. 

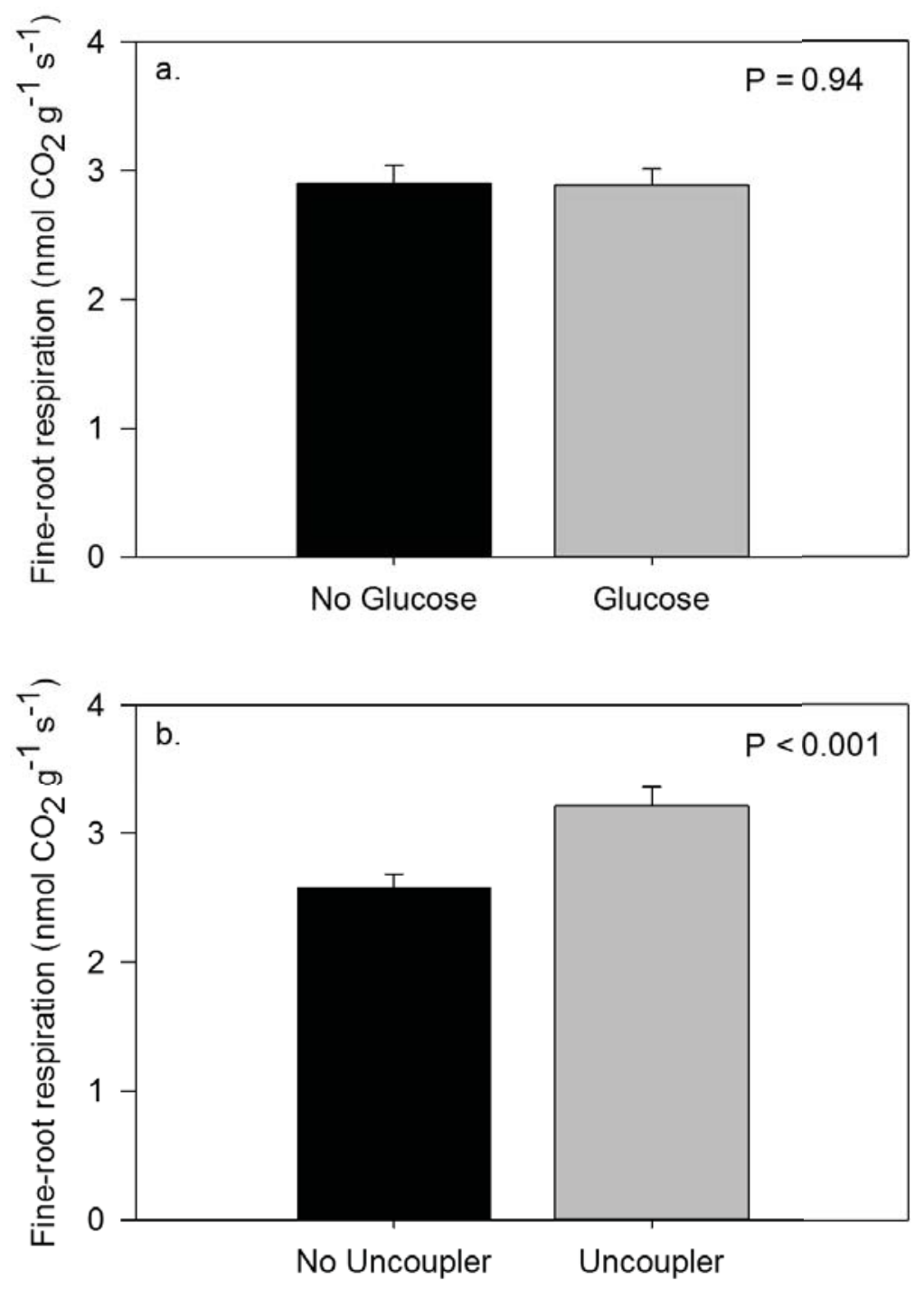

Figure 2.3. Average fine-root respiration (nmol $\left.\mathrm{CO}_{2} \mathrm{~g}^{-1} \mathrm{~s}^{-1}\right)$ with (gray bars) and without (black bars) the addition of exogenous sugar (a., glucose) and respiratory uncoupler (b., CCCP) across all dates at ambient temperature. Average temperatures with standard error in parentheses for each sample date were: $11.4{ }^{\circ} \mathrm{C}(0.09)$ and $14.9{ }^{\circ} \mathrm{C}(0.10), 13.3{ }^{\circ} \mathrm{C}$ $(0.08)$ and $16.8^{\circ} \mathrm{C}(0.09)$, and $10.2{ }^{\circ} \mathrm{C}(0.09)$ and $14.0^{\circ} \mathrm{C}(0.09)$ for the non-heated and heated plots for May, July, and September respectively. Error bars are stand error of the mean and significance was set at $\alpha=0.05$. 


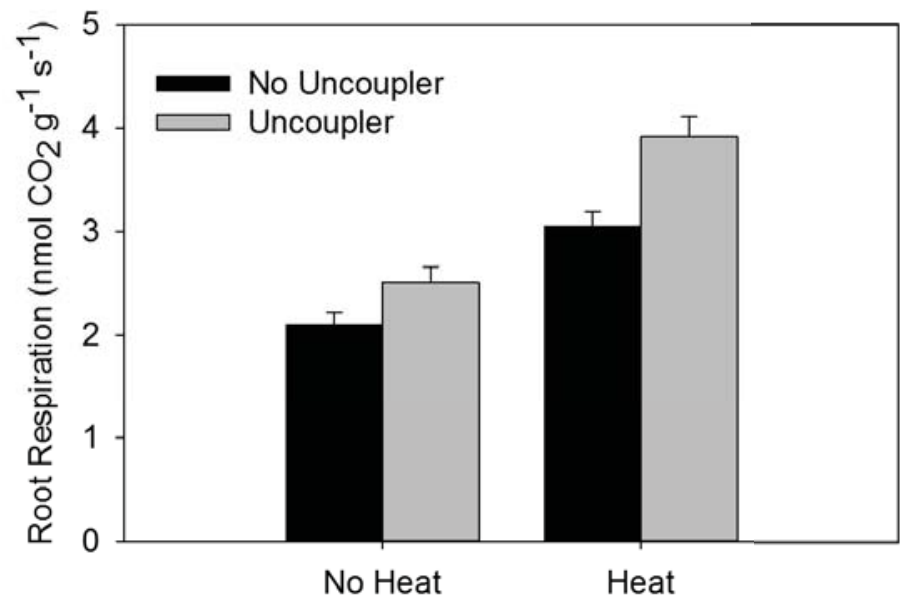

Figure 2.4. Comparison of effects on average fine-root respiration $\left(\mathrm{nmol} \mathrm{CO} \mathrm{g}^{-1} \mathrm{~s}^{-1}\right)$ of the respiratory uncoupler (CCCP) for treatments receiving no heat (control, water) or heat (heat, heat + water) across all dates at ambient temperature. Average temperatures with standard error in parentheses for each sample date were: $11.4^{\circ} \mathrm{C}(0.09)$ and $14.9^{\circ} \mathrm{C}$ (0.10), $13.3{ }^{\circ} \mathrm{C}(0.08)$ and $16.8^{\circ} \mathrm{C}(0.09)$, and $10.2^{\circ} \mathrm{C}(0.09)$ and $14.0^{\circ} \mathrm{C}(0.09)$ for the non-heated and heated plots for May, July, and September respectively. Black bars represent basal respiration rate, and gray bars represent respiratory stimulation after the addition of CCCP. Error bars represent standard error of the mean. 


\section{References}

Amthor J.S. (2000) The McCree-de Wit-Penning de Vries-Thornley respiration paradigms: 30 years later. Annals of Botany 86, 1-20.

Amthor J.S. (1984) The role of maintenance respiration in plant growth. Plant, Cell and Environment 7, 561-569.

Atkin O.K., Edwards E.J., Lovey B.R. (2000a) Response of root respiration to changes in temperature and its relevance to global warming. New Phytologist 147, 141-154.

Atkin O.K., Holly C., Ball M.C. (2000b) Acclimation of snow gum (Eucalyptus pauciflora) leaf respiration to seasonal and diurnal variations in temperature: the importance of changes in the capacity and temperature sensitivity of respiration. Plant Cell and Environment 23, 15-26.

Atkin O.K., Tjoelker M.G. (2003) Thermal acclimation and the dynamic response of plant respiration to temperature. TRENDS in Plant Science 8(7), 343-351.

Atkin O.K., Sherlock, D., Fitter A.H., Jarvis S., Hughes J.K., Campbell C., ..., Hodge A. (2009) Temperature dependence of respiration in roots colonized by arbuscular mycorrhizal fungi. New Phytologist 182(1), 188-189.

Boden T.A., Marland G., Andres R.J. (2012) Global, Regional, and National Fossil-Fuel $\mathrm{CO}_{2}$ Emissions. Carbon Dioxide Information Analysis Center, Oak Ridge National Laboratory, U.S. Department of Energy, Oak Ridge, Tenn., U.S.A. doi 10.3334/CDIAC/00001_V2012

Bouma T.J., Broekhuysen A.G.M., Veen B.W. (1996) Analysis of root respiration of Solanum tuberosum as related to growth, ion uptake and maintenance of biomass. Plant Physiology and Biochemistry. 34, 795-806.

Bouma T.J., Devisser R., Janssen J.H.J.A., Dekock M.J., Vanleeuwen P.H., Lambers H. (1994) Respiratory energy requirements and rate of protein turnover in vivo determined by the use of an inhibitor of protein synthesis and a probe to assess its effect. Physiologia Plantarum 92, 585-594.

Bryla D.R., Bouma T.J., Eissenstat D.M. (1997) Root respiration in citrus acclimates to temperature and slows during drought. Plant Cell and Environment. 20, 1411-1420.

Burton A.J., Jarvey J.C., Jarvi M.P., Zak D.R., Pregitzer K.S. (2012) Chronic N deposition alters root respiration-tissue $\mathrm{N}$ relationship in northern hardwood forests. Global change biology 18(1), 258-266. 
Burton A.J., Pregitzer K.S. (2003) Field measurements of root respiration indicate little to no seasonal temperature acclimation for sugar maple and red pine. Tree Physiology 23, 273-280.

Burton, A. J., \& Pregitzer, K. S. (2002) Measurement carbon dioxide concentration does not affect root respiration of nine tree species in the field. Tree Physiology, 22(1), 67-72.

Burton A.J., Pregitzer K.S., Hendrick R.L. (2000) Relationships between fine root dynamics and nitrogen availability in Michigan northern hardwood forests. Oecologia 125(3), 389-399.

Burton A.J., Pregitzer K.S., Zogg G.P., Zak D.R. (1996) Latitudinal variation in sugar maple fine root respiration. Canadian Journal of Forest Research 26(10), 1761-1768.

Burton A.J., Zogg G.P., Pregizter K.S., Zak D.R. (1997) Effect of measurement $\mathrm{CO}_{2}$ concentration on sugar maple root respiration. Tree Physiology 17, 421-427.

Collins W.J., Bellouin N., Doutriaux-Boucher M., Gedney N., Halloran P., Hinton T., Woodward S. (2011). Development and evaluation of an Earth-system model HadGEM2. Geoscientific Model Development Discussion 4, 997-1062.

Cotrufo M.F., Ineson P., Scott A. (1998) Elevated CO2 reduces the nitrogen concentration of plant tissues. Global Change Biology, 4(1), 43-54.

Chow P.S., Landhäusser S.M. (2004) A method for routine measurements of total sugar and starch content in woody plant tissues. Tree Physiology 24, 1129-1136.

Covey-Crump E.M., Attwood R.G., Atkin O.K. (2002) Regulation of root respiration in two species of Plantago that differ in relative growth rate: the effect of short- and longterm changes in temperature. Plant, Cell and Environment 25, 1501-1513.

Drake J.E., Stoy P.C., Jackson R.B., DeLucia E.H. (2008) Fine-root respiration in a loblolly pine (Pinus taeda L.) forest exposed to elevated $\mathrm{CO}_{2}$ and $\mathrm{N}$ fertilization. Plant, Cell and Environment 31(11), 1663-1672.

Douce R., Neuburger M. (1989) The uniqueness of plant mitochondria. Annual review of plant biology, 40(1), 371-414.

Eno C.F. (1960) Nitrate production in the field by incubating the soils in polyethylene bags. Soil Science Society of America, Proceedings 24, 277-279.

Fahey T.J., Jacobs K.R., Sherman R.E. (2012) Fine root turnover in sugar maple estimated by 13C isotope labeling. Canadian Journal of Forest Research, 42(10), 17921795. 
Gifford R.M. (2003) Plant respiration in productivity models: conceptualisation, representation and issues for global terrestrial carbon-cycle research. Functional Plant Biology 30, 171-186.

Grace J., Rayment M. (2000) Respiration in the balance. Nature, 404(6780), 819-820.

Gunderson C.A., O’Hara K.H., Campion C.M., Walker A.V., Edwards N.T. (2010) Thermal plasticity of photosynthesis: the role of acclimation in forest responses to a warming climate. Global Change Biology 16, 2272-2286.

Hanson P.J., Edwards N.T., Garten C.T., Andrews J.A. (2000) Separating root and soil microbial contributions to soil respiration: A review of methods and observations. Biogeochemistry 48, 115-146.

Hendrick R.L., Pregitzer K.S. (1992) The demography of fine roots in a northern hardwood forest. Ecology 1094-1104.

Himmelbauer M.L. Loiskandl W., Kastanek F. (2004) Estimating length, average diameter and surface area of roots using two different image analyses systems. Plant and Soil 260, 111-120.

Högberg P., Nordgren A., Ågren G.I. (2002) Carbon allocation between tree root growth and root respiration in boreal pine forest. Oecologia 132, 579-581.

Hopkins F., Gonzalez-Meler M.A., Flower C.E., Lynch D.J., Czimczik C., Tang J., Subke J. (2013) Ecosystem-level controls on root-rhizosphere respiration. New Phytologist 199, 339-351.

Jarvi M.P., Burton A.J. (2013) Acclimation and soil moisture constrain sugar maple root respiration in experimentally warmed soil. Tree Physiology 33, 949-959.

Johnson I.R. (1990) Plant respiration in relation to growth, maintenance, ion uptake and nitrogen assimilation. Plant, Cell and Environment 13, 319-328.

Kerhoulas L.P., Kane J.M. (2012) Sensitivity of ring growth and carbon allocation to climatic variation vary within ponderosa pine trees. Tree Physiology 32(1), 13-23.

Kositsup B., Montpied P., Kasemsap P., Thaler P., Ameglio T., Dreyer E. (2009) Photosynthetic capacity and temperature responses of photosynthesis of rubber trees (Hevea brasiliensis Mull Arg.) acclimate to changes in ambient temperatures. Trees 23, 357-365.

Lacointe A. (2000) Carbon allocation among tree organs: A review of basic processes and representation in functional-structural tree models. Annals of Forest Science 57, 521533. 
Larigauderie A., Körner C. (1995) Acclimation of leaf dark respiration to temperature in alpine and lowland plant species. Annals of Botany 76, 245-252.

Lee T.D., Reich P.B., Bolstad P.V. (2005) Acclimation of leaf respiration to temperature is rapid and related to specific leaf area, soluble sugars and leaf nitrogen across three temperate deciduous tree species. Functional Ecology 19(4), 640-647.

Litton C.M., Raich J.W., Ryan M.G. (2007) Carbon allocation in forest ecosystems. Global Change Biology 13, 2089-2109.

Loveys B.R., Atkinson L.J., Sherlock D.J., Roberts R.L., Fitter A.H., Atkin O.K. (2003) Thermal acclimation of leaf and root respiration: an investigation comparing inherently fast- and slow-growing plant species. Global Change Biology 9, 895-910.

Loveys B.R., Scheurwater I., Pons T.L., Fitter A.H., Atkin O.K. (2002). Growth temperature influences the underlying components of relative growth rate: an investigation using inherently fast- and slow-growing plant species. Plant, Cell and Environment 25, 975-987.

Medyln B.E., Loustau D., Delzon S. (2002) Temperature response of parameters of a biomchemically based model of photosynthesis. I. Seasonal changes in mature maritime pine (Pinus pinaster Ait.). Plant, Cell and Environment 25, 1155-1165.

Melillo J.M., Butler S., Johnson J., Mohan J., Steudler P., Lux H., ..., Tang J. (2011) Soil warming, carbon-nitrogen interactions, and forest carbon budgets. Proceedings of the National Academy of Sciences of the United States of America 108(23), 9508-9512.

Niinemets Ü, Valladares, F. (2004) Photosynthetic acclimation to simultaneous and interacting environmental stresses along natural light gradients: optimality and constraints. Plant Biology, 6(3), 254-268.

Poorter H., Van Der Werf A., Atkin O.K., Lambers H. (1991) Respiratory energy requirements of roots vary with the potential growth rate of a species. Physiologia Plantarum 83, 469-475.

Reich P.B., Walters M.B., Tjoelker M.G., Vanderklein D., Buschena C. (1998) Photosynthesis and respiration rates depend on leaf and root morphology and nitrogen concentration in nine boreal tree species differing in relative growth rate. Functional Ecology, 12(3), 395-405.

Scheuwater I., Cornelissen C., Dictus F., Welschen R., Lambers H. (1998) Why do fastand slow-growing species differ so little in their rate of root respiration, considering the large differences in rate of growth and ion uptake? Plant, Cell and Environment 21, 9951005.

Slot M., Kaoru K. (2015) General patterns of acclimation of leaf respiration to elevated temperatures across biomes and plant types. Oecologia 177: 885-900. 
Smith N.G., Dukes J.S. (2013) Plant respiration and photosynthesis in global-scale models: incorporation acclimation to temperature and $\mathrm{CO}_{2}$. Global Change Biology 19(1), 45-63.

Tjoelker M.G., Oleksyn J., Reich P.B., Żytkowiak R. (2008) Coupling of respiration, nitrogen, and sugars underlies convergent temperature acclimation in Pinus banksiana across wide-ranging sites and populations. Global Change Biology 14(4), 782-797.

Tjoelker M.G., Reich P.B., Oleksyn J. (1999) Changes in leaf nitrogen and carbohydrates underlie temperature and $\mathrm{CO} 2$ acclimation of dark respiration in five boreal tree species. Plant, Cell \& Environment 22(7), 767-778.

Valentini R., Matteucci G., Dolman A.J., Schulze E.-D., Rebmann C., Moors, E.J., ... \& Jarvis P.G. (2000) Respiration as the main determinant of carbon balance in European forests. Nature 404(6780), 861-865.

Van Der Werf A., Kooijman A., Welschen R., Lambers H. (1988) Respiratory energy costs for the maintenance of biomass, for growth and for ion uptake in roots of Carex diandra and Carex acutiformis. Physiologia Plantarum 72, 483-491.

Vogel J., Bronson D., Gower S.T., Schuur E.A.G. (2014) The response of root and microbial respiration to the experimental warming of a boreal black spruce forest. Canadian Journal of Forest Research doi 10.1139/cjfr-2014-0056.

Wagner F., Below R., Klerk P.D., Dilcher D.L., Joosten H., Kürschner W.M., Visscher H. (1996) A natural experiment on plant acclimation: lifetime stomatal frequency response of an individual tree to annual atmospheric $\mathrm{CO} 2$ increase. Proceedings of the National Academy of Sciences, 93(21), 11705-11708.

Woodwell G.M., Mackenzie F.T., Houghton R.A., Apps M.J., Gorham E., Davidson E.A. (1995) Will the Warming Feed the Warming? In Biotic Feedbacks in the Global Climatic System (Woodwell G.M., Mackenzie F.T., eds) Oxford University Press, New York.

Zhou Y., Tang J., Melillo J.M., Butler S., Mohan J.E. (2011) Root standing crop and chemistry after six years of soil warming in a temperate forest. Tree Physiology 31, 707717.

Zogg G.P., Zak D.R., Burton A.J., Pregitzer K.S. (1996) Fine root respiration in northern hardwood forests in relation to temperature and nitrogen availability. Tree Physiology 16, 719-725. 


\title{
Chapter 3: Root respiration and biomass responses to experimental soil warming vary with root diameter and soil depth ${ }^{1}$
}

\begin{abstract}
Approximately half of plant gross primary productivity is returned to the atmosphere through autotrophic respiration. Future climatic warming may impact this $\mathrm{C}$ flux and possibly create a feedback with atmospheric $\mathrm{CO}_{2}$ concentration and ultimately climate change. It has been found that plant tissue respiration often can acclimate to increased temperatures. Respiration of sugar maple (Acer saccharum Marsh.) surface fine roots $(<1 \mathrm{~mm})$ has been found to partially acclimate to experimental increases in soil temperature, but it is unknown how different sized roots and roots at deeper depths respond to sustained increases in soil temperature regime. This study was conducted in August 2013 at the SMART (sugar maple altered rainfall and temperature) experiment in a natural sugar maple forest that has received a fully factorial combination of increased soil temperature $\left(+4\right.$ to $\left.5{ }^{\circ} \mathrm{C}\right)$ and supplemental precipitation since 2010. The purpose of this study was to determine if acclimation occurs for various root diameters $(<1,1-2$, and 2-10 $\mathrm{mm})$ at three soil depths $(0-10,10-30$, and 30-50 cm). Additionally, this study determined if root biomass had changed as a result of these experimental treatments for the same root diameters and soil depths. There was partial acclimation of the fine-roots $(<1 \mathrm{~mm})$ at $0-10 \mathrm{~cm}$ with $32 \%$ more respiration in the heated treatments versus the nonheated treatments, which was far less than the expected increase in respiration for $+5{ }^{\circ} \mathrm{C}$ in soil temperature and a $\mathrm{Q}_{10}$ of 2-3. However, there was no evidence for acclimation of deeper fine roots at the 10-30 and 30-50 cm depths, for which soil warming caused respiration to more than double. There was evidence of acclimation of roots 1-2 $\mathrm{mm}$ in diameter at the $0-10 \mathrm{~cm}$ depth but not for the larger diameter roots at any of the three soil depths. Root biomass was not altered by the soil warming and moisture addition treatments. Ultimately, ecosystem level root respiration $\left(\mu \mathrm{mol} \mathrm{CO}_{2} \mathrm{~m}^{-2} \mathrm{~s}^{-1}\right)$ was $61 \%$ greater for heated treatments than non-heated treatments. Although there has been some down-regulation of respiration in roots from experimentally warmed soil, there is still an increased loss of $\mathrm{C}$ returning to the atmosphere, potentially reducing that available for respiration and biomass production in other portions of the tree system.
\end{abstract}

${ }^{1}$ The material contained in this chapter has not been submitted to any journal yet. Mickey Jarvi is the sole contributor in designing the experiment, collecting data, analyzing and interpreting data, and writing the manuscript. Andrew Burton will be listed as a coauthor when the manuscript is submitted to a future journal. 


\section{Introduction}

Forests around the globe contain more than $50 \%$ of total terrestrial organic carbon (C) (Goodale et al. 2002) and about $40 \%$ of all below-ground terrestrial C (Dixon et al.

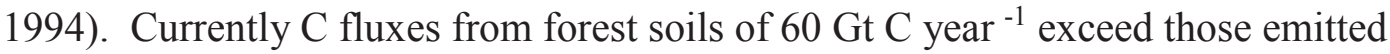
through the combustion of fossil fuels by an order of magnitude, or about $6 \mathrm{Gt} \mathrm{C}$ year ${ }^{-1}$ (Giardina et al. 2005). However, this large C flux is one of the least understood among all terrestrial ecosystem C fluxes (Litton and Giardina 2008, Litton et al. 2007). Yearly, total canopy photosynthesis (gross primary productivity, GPP) is allocated between above- and below-ground production and respiration. Litton and Giardina (2008) propose that two critical questions are still present in understanding belowground terrestrial C fluxes: "how much of GPP do forests partition below-ground and what is the ultimate fate of this carbon?" and "how will climate change impact both the overall partitioning of GPP to below-ground C flux, and the partitioning of below-ground C flux to production vs. respiration?". Root production can utilize much of net primary productivity (NPP) in forests (Hendrick and Pregitzer 1993, Schimel et al. 1994), the rhizosphere can return as much as $52 \%$ of GPP back to the atmosphere (Lambers et al. 2008), and root respiration can account for as much as $60 \%$ of total soil respiration in sugar maple (Acer saccharum Marsh.) forests (Pregitzer et al. 1998). What is unknown is how these processes will be affected by global climate change. Currently the worldwide projected warming has been estimated to be between +1.1 and $6.4{ }^{\circ} \mathrm{C}$ by the year 2100 (Alley et al. 2007) and this projected warming could have consequences on C balance above- and below-ground by altering processes such as photosynthesis and respiration 
(Canadell et al. 2007, Melillo et al. 1990, 1995, Shaver et al. 2000). Additionally, current models for the United States predict that under low emission scenarios annual average temperatures will rise by $4.5^{\circ} \mathrm{C}$ and under high emission scenarios by up to $7.2^{\circ} \mathrm{C}$ by 2090 (Karl et al. 2009).

Root functions differ with changes in root diameter or order and with rooting depth (Pregitzer et al. 1998) with finer, low order roots, especially those at shallower depth, performing the majority of root respiration and nutrient and water uptake while deeper and coarser roots perform functions such as transport, support and carbohydrate storage (Xia et al. 2010, McCormack et al. 2015). It has been found that root biomass is usually smaller when nutrient availability is higher within the same geographical area (Finér et al. 2007, Helmisaari et al. 2007) or water availability is limiting (Meier and Leuschner 2008).

Previously, Jarvi and Burton (2013) found evidence that surface fine $(<1 \mathrm{~mm})$ roots of sugar maple in a northern soil warming experiment exhibited respiratory acclimation to elevated soil temperature representative of a future climate scenario of +4 to $5{ }^{\circ} \mathrm{C}$ by 2100 . However, they did not find evidence that fine-root biomass had been affected by several years of soil warming. These findings are in contrast to those of Melillo et al. (2011) for the Harvard Forest soil warming experiment in central Massachusetts, which showed no indication of acclimation of fine-root respiration to elevated temperatures, but did find reductions in fine-root biomass. These two different scenarios, however, both result in a reduction in ecosystem fine-root respiration, relative to what would be predicted using an exponential response of respiration to temperature, 
as both a down-regulation in root-respiration (acclimation) or a reduction of root biomass (ultimately less tissue to respire) would constrain the contribution of ecosystem level root respiration.

This study was conducted at the SMART (sugar maple altered rainfall and temperature) experiment in August 2013, during the fourth growing season after the initiation of the soil warming treatments. The objective was to determine if acclimation of specific root respiration ( $\mathrm{nmol} \mathrm{CO}_{2} \mathrm{~g}^{-1} \mathrm{~s}^{-1}$ ) still existed for fine-roots from the shallow soil depths of $0-10 \mathrm{~cm}$ to support the previous findings of Jarvi and Burton (2013), and to investigate the presence or absence of acclimation on several root diameter classes $(<1,1$ 2, and 2-10 $\mathrm{mm})$ and at several soil depths (0-10, 10-30, and 30-50 cm). Additionally, root biomass $\left(\mathrm{g} \mathrm{m}^{-2}\right)$ was assessed to determine if there has been any effect of soil warming on root biomass for any root size class or soil depth.

\section{Methods}

\section{Study site location}

This study was conducted at the SMART (sugar maple altered rainfall and temperature) experiment in a natural second-growth sugar maple (Acer saccharum Marsh.) forest at Michigan Technological University's Ford Center and Forest (46 $38.41^{\text {' }}$ $\mathrm{N}$ latitude, $88^{\circ} 29.07^{\prime} \mathrm{W}$ longitude). This fully factorial heating and water addition experiment has been warming the soil from $1.5 \mathrm{~m}$ above soil surface with infrared lamps since 2010 (Jarvi and Burton 2013). The treatment plots are $10 \mathrm{~m}$ by $10 \mathrm{~m}$, with four treatments replicated three times: control, heat $\left(+4\right.$ to $5{ }^{\circ} \mathrm{C}$ above ambient soil 
temperature), water (plus 30\% of average growing season ambient precipitation), and heat + water. The treatments were applied during the snow-free season with a general ramping up of soil temperature for the heated plots during the spring, and ramping down of temperature on the heated plots during the fall. The infrared lamps were shut off but left in place during the snow season (approximately early November-April). Since 2009 soil temperature and soil moisture were measured at depths of 2, 5, and $10 \mathrm{~cm}$ below soil surface (Em50 data loggers with 5TM temperature/moisture probes, Decagon Devices, Inc., Pullman, Washington, DC, USA). Additionally, at plot center, soil temperature at soil depths of 1,5 , and $15 \mathrm{~cm}$ and air temperature at $1 \mathrm{~m}$ above soil surface were also measured (Hobo U12 4-external channel outdoor/industrial data logger with TMC6-HA probes, Onset Computer Corporation, Bourne, MA, USA). In 2014 deeper temperature probes were installed at 20 and $30 \mathrm{~cm}$ to ensure that the temperature differential extended to deeper soil depths (Figure 3.1).

Sugar maple dominates the site with $89.3 \%$ of the $21.7 \mathrm{~m}^{2} \mathrm{ha}^{-1}$ of basal area. Other less dominant species include: American elm (Ulmus americana L.), eastern hemlock (Tsuga canadensis (L.) Carr.), eastern hophornbeam (Ostrya virginiana (Mill.) K. Koch), and yellow birch (Betula alleghaniensis Britton). The soil is classified as a sandy loam with $62 \%$ sand, $29 \%$ silt, and $9 \%$ clay for the $0-10 \mathrm{~cm}$ depth and $59 \%$ sand, $29 \%$ silt, and $12 \%$ clay for the $10-20 \mathrm{~cm}$ depth. A fragipan occurs at approximately 40 $\mathrm{cm}$ below the soil surface.

\section{Sample collection}


Soil cores were collected in late August 2013, from which roots were extracted to determine root respiration rates and root biomass. Three $10 \mathrm{~cm}$ diameter cores were taken per plot at three depths: $0-10 \mathrm{~cm}, 10-30 \mathrm{~cm}$, and $30-50 \mathrm{~cm}$ using a steel corer designed for use in rocky forest soils (Jurgensen et al. 1977), for a total of 9 samples per plot and 108 samples for the entire study site. Roots for respiration measurements were immediately extracted from the soil samples, with the residual soil and roots stored on ice, then returned to the laboratory where they were stored in $-20^{\circ} \mathrm{C}$ until further analysis.

\section{Root respiration}

Root respiration measurements were conducted following the procedure outlined by Jarvi and Burton (2013) and Burton et al. (2012), with the use of two open-system infrared gas analyzers (CIRAS-1 and CIRAS-2, PP Systems). Custom aluminum cuvettes that could be placed in water baths to control temperature were connected to the IRGAs. Root samples were separated from the soil depth increment samples and sorted into one of three diameter classes $(<1,1-2,2-10 \mathrm{~mm})$ to obtain approximately $2 \mathrm{~g}$ fresh weight of roots per diameter class. The root samples were hand cleansed of soil and organic debris before measurement of root respiration commenced (usually within 15 minutes of sample collection). Respiration rates $\left(\mathrm{nmol} \mathrm{CO}_{2} \mathrm{~s}^{-1}\right)$ were recorded after allowing 15 minutes to equilibrate to the cuvette temperature and the measurement atmosphere of $1000 \mu \mathrm{l} \mathrm{l}^{-1} \mathrm{CO}_{2}$, representative of soil atmospheric conditions. Root respiration rates for all samples were measured at ambient soil temperature and at a common reference temperature of $18{ }^{\circ} \mathrm{C}$. It has been shown that respiration measurements at a common reference temperature are useful for assessing differences in 
metabolic capacity that might be indicative of acclimation (Atkin et al. 2000). Roots were placed on ice, transported back to the laboratory, and stored at $-20{ }^{\circ} \mathrm{C}$ until further analysis. Later, root respiration samples were cleansed with deionized water to remove any residual adhering soil not removed during field cleaning, dried at $65{ }^{\circ} \mathrm{C}$ for 48 hours, and weighed to enable calculation specific root respiration rates $\left(\mathrm{nmol} \mathrm{CO} \mathrm{g} \mathrm{g}^{-1} \mathrm{~s}^{-1}\right)$.

\section{Root biomass}

Root biomass samples were obtained from the soil cores collected and stored in the $-20{ }^{\circ} \mathrm{C}$ freezer. Soil cores were weighed for field fresh weight after thawing in the refrigerator for $24-48$ hours. Soil was passed through a $6.2 \mathrm{~mm}$ sieve to remove any rocks. These rocks were weighed for use in bulk density measurements and archived. The soil was then passed through a $2 \mathrm{~mm}$ sieve and any remaining pebbles, debris, and non-tree roots were discarded. Only live tree roots (pliable and brown to white in color) were collected and stored in the freezer, while dead roots (brittle and brown to black in color) were discarded. Root samples were then cleansed in deionized water, sorted into the same diameter classes as the root respiration classes $(<1,1-2,2-10 \mathrm{~mm})$ and dried at $65{ }^{\circ} \mathrm{C}$ for 48 hours. Dry weights obtained from the respiration samples were added to those sorted from the residual soil samples to determine total root biomass.

\section{Ecosystem root respiration}

Ecosystem level root-respiration was calculated as the product of specific root respiration ( $\left.\mathrm{nmol} \mathrm{CO} \mathrm{Cg}^{-1} \mathrm{~s}^{-1}\right)$ and root biomass $\left(\mathrm{g} \mathrm{m}^{-2}\right)$. Averages were obtained from these values and then summed across treatments and root diameters. 


\section{Statistical analysis}

All statistical analyses were conducted in the R environment ( $\mathrm{R}$ Development Core Team 2008). Two-way nested analysis of variance (ANOVA) was used to test for differences in specific root respiration among treatments (heat \& water) with nested size class and rooting depth effects also examined. Two-way analysis of variance (ANOVA) was used to test differences in root biomass to treatments (heat $\&$ water) with size class and rooting depth. The Agricolae package was used in R to conduct post-hoc Tukey's honest significant difference (HSD) test to find significant differences in means from the ANOVA analyses.

\section{Results}

\section{Root respiration}

The average soil temperatures across all three soil depths $(0-10,10-30,30-50 \mathrm{~cm})$ on the sample date were $16.4{ }^{\circ} \mathrm{C}$ and $21.8{ }^{\circ} \mathrm{C}$ for the non-heated and heated treatments respectively. At ambient temperature, root specific respiration rates were higher for the heated treatments versus the non-heated treatments (Table 3.1, Figure 3.2). Effects were greater for the $<1 \mathrm{~mm}$ roots and $2-10 \mathrm{~mm}$ roots (significant heat $\mathrm{x}$ diameter interaction, Table 1), with $71 \%$ more root respiration for the $1 \mathrm{~mm}$ roots (an average across soil depths of 3.67 versus $\left.2.14 \mathrm{nmol} \mathrm{CO}_{2} \mathrm{~g}^{-1} \mathrm{~s}^{-1}\right)$ and $69 \%$ more the $2-10 \mathrm{~mm}$ roots $(1.05$ versus $0.62 \mathrm{nmol} \mathrm{CO} \mathrm{gg}^{-1} \mathrm{~s}^{-1}$ ) for the heated versus non-heated treatments, compared to an $53 \%$ response for roots of $1-2 \mathrm{~mm}\left(1.55\right.$ versus $\left.1.01 \mathrm{nmol} \mathrm{CO}_{2} \mathrm{~g}^{-1} \mathrm{~s}^{-1}\right)$. In addition, specific respiration rates were greater for smaller diameter roots and were lower for all 
root size classes in deeper soil (Table 3.1, Figure 3.2), with differences among root diameter classes being less pronounced in deeper soil (significant root diameter x soil depth interaction in Table 3.1).

At the reference temperature of $18{ }^{\circ} \mathrm{C}$, root respiration rates were slightly less on the heated versus the non-heated treatments $(P=0.082)$ (Figure 3.3), with this effect driven largely by lower respiration rates for the heated treatments in surface soil roots, with reduced effects in deeper soil $(\mathrm{P}=0.082$ for heat $\mathrm{x}$ depth interaction). Similar to measurements at ambient temperature, there was a significant decrease in root respiration at reference temperature for larger root diameter and deeper soil depth (Table 3.1, Figure 3.3), with differences among diameters less pronounced in deeper soil (root diameter $\mathrm{x}$ soil depth interaction, Table 3.1).

\section{Root biomass}

Root biomass was not altered by soil warming or water additions (Table 3.2, Table 3.3, Figure 3.4). There was a significant difference in root biomass across root diameters, with greater biomass in $<1 \mathrm{~mm}$ and $2-10 \mathrm{~mm}$ roots than in 1-2 $\mathrm{mm}$ roots, and an indication that fine-root biomass declined with soil depth $(P<0.001$, Table 3.2$)$. A significant soil depth $\mathrm{x}$ root diameter interaction results from the tendency of fine root biomass to be greatest in surface soil for $<1 \mathrm{~mm}$ diameter roots and greatest at the $30-50$ cm depth for larger diameter roots $(P=0.021$, Table 3.2, Figure 3.5).

\section{Ecosystem root respiration}


For the sample date, total ecosystem root respiration rate was calculated by multiplying respiration rates by biomass for each root size and diameter class and summing. There was 17 and $4 \%$ more ecosystem respiration $\left(\mu \mathrm{mol} \mathrm{CO} \mathrm{Cm}^{-2} \mathrm{~s}^{-1}\right)$ for the heat and heat + water treatment compared to the control for the 0-10 cm depth, 107 and $40 \%$ more at the $10-30 \mathrm{~cm}$ depth (Table 3 ). Overall, the heated (heat and heat + water) treatments respired at a rate of $3.30 \mu \mathrm{mol} \mathrm{CO} \mathrm{CO}^{-2} \mathrm{~s}^{-1}$, which was $61 \%$ more than the nonheated plots (control and water; $2.05 \mu \mathrm{mol} \mathrm{CO} \mathrm{m}^{-2} \mathrm{~s}^{-1}$.

\section{Discussion}

Fine-root biomass $(<1 \mathrm{~mm})$ has remained unchanged in the $0-10 \mathrm{~cm}$ depth in response to experimental warming at the SMART experiment since 2010 (Jarvi and Burton 2013), and we similarly find no evidence that root biomass in any size class or depth increment has been altered by warming (Figure 3.4, Table 3.4). This 0-10 $\mathrm{cm}$ soil is the soil depth where the majority of fine roots associated with acquisition of nutrients are located. There is evidence that acclimation is still occurring at the site for fine-root respiration at the $0-10 \mathrm{~cm}$ depth (lower respiration at the reference temperature for roots from warmed soil, Figure 3) though not at deeper depths. Melillo et al. (2011) found no evidence of acclimation in root respiration in a soil warming experiment at the Harvard Forest after 7 years of experimental soil warming. However, they did observe a decrease in fine-root biomass in the $0-10 \mathrm{~cm}$ depth that was sufficient to constrain the amount of total $\mathrm{C}$ released back to the atmosphere by root respiration at the ecosystem level. In our study, slight acclimation in surface fine roots, with no change in root biomass, somewhat constrained root system respiration. 
However, lack of acclimation for deeper roots and no change in biomass led to large overall increases in root system respiration. Earth systems models generally use a Q10 of 2.0 for root respiration in climate change models in response to elevated temperatures. Jarvi and Burton (2013) found that the respiration of roots on the control plots responds to seasonal changes in soil temperature with a $\mathrm{Q}_{10}$ of 2.7. This would create an expected increase in root respiration of $71 \%$ on the heated versus the nonheated treatments for the temperature increase of $5.4{ }^{\circ} \mathrm{C}$ existing during the sampling period. Fine roots $(<1 \mathrm{~mm})$ respiration increased only $32 \%$ more at the $0-10 \mathrm{~cm}$ depth $(P$ $=0.005)$ but 111 and $211 \%$ more at the $10-30$ and $30-50 \mathrm{~cm}$ depths respectively.

Previous exploration of how far the heat transfers to these deeper soil depths on the heated treatments has shown that we achieve our target of $+4-5^{\circ} \mathrm{C}$ all the way to at least $30 \mathrm{~cm}$ but most likely beyond that (Figure 3.1). However, this is the first time larger diameter roots and roots at different soil depths have been measured for the warming experiment. It could very well be the case that the $\mathrm{Q}_{10}$ for these different roots is vastly different from the $<1 \mathrm{~mm}$ roots from the $0-10 \mathrm{~cm}$ depth. The approximate growing season for Alberta MI is 124 days, so using this as a baseline and extrapolating the rates of $2.05 \mu \mathrm{mol} \mathrm{CO} \mathrm{C} \mathrm{m}^{-2} \mathrm{~s}^{-1}$ for the non-heated treatments (control and water) and $3.29 \mu \mathrm{mol}$ $\mathrm{CO}_{2} \mathrm{~m}^{-2} \mathrm{~s}^{-1}$ for the heated treatments (heat and heat + water), the heated plots would release 13.2 more $\mathrm{g} \mathrm{CO}_{2} \mathrm{~m}^{-2}$ growing season ${ }^{-1}$ than the non-heated plots with 35.2 and $22.0 \mathrm{~g} \mathrm{CO}_{2} \mathrm{~m}^{-2}$ growing season ${ }^{-1}$ for the heated and non-heated plots respectively. These scenarios both indicate that without total homeostasis of root system respiration to increases in soil temperature, then the sugar maple tree systems may approach a scenario 
of reaching a reduced net carbon balance. Total homeostasis would be no difference in ecosystem root respiration at ambient soil temperature between heated and non-heated treatments in the presence of a temperature differential between the heated and nonheated treatments of $4-5^{\circ} \mathrm{C}$, which is not these case currently (Figure 3.2).

These trees are at full leaf area capacity, and future climate scenarios do not predict that more solar radiation will be intercepting the earth, but changes in GPP due to any climatic variable is complicated and each variable has confounding effects on the other. In addition, growing season length will increase, but without a corresponding increase in precipitation, this may not result in large increases in GPP (Collins 2015). If root system respiration increases without a sufficient increase in GPP, then NPP may decrease potentially having a negative effect on the competitive ability and survivability of sugar maple in this region.

Potential issues exist with regard to $\mathrm{C}$ available for other uses (i.e. bole growth) unless other types of adjustments not observed in this study ultimately occur in the longterm. Acclimation is occurring at the smaller diameter roots $(<1$ and 1-2 mm) at the 0-10 cm depth, but acclimation is not apparent in large diameter surface roots or any root diameter at deeper soil depths (Figure 3). Examples of other adjustments would be the response Melillo et al. (2011) saw with regard to decreased fine-root biomass for the heated treatments versus the non-heated treatments. Additionally, Kratz (2014) measured a decrease in mycorrhizal abundance in response to the heated treatments at the SMART experiment. This decrease would reduce $\mathrm{C}$ allocation to the entire root/mycorrhizal 
absorbing system, but not enough to offset the increase in root respiration measured in this study and in Jarvi and Burton (2013).

\section{Conclusion}

Fine-root respiration $(<1 \mathrm{~mm})$ showed an indication that it had partially acclimated to soil warming at the $0-10 \mathrm{~cm}$ depth, somewhat limiting the increase in root respiration with soil warming. However, there were large increases in root respiration in response to soil warming in the deeper $(10-30$ and $30-50 \mathrm{~cm})$ soil depths. The evidence for acclimation at ambient temperature is apparent in the fine-roots $(<1 \mathrm{~mm})$ from the 0 $10 \mathrm{~cm}$ depth with only $32 \%$ more respiration on the heated treatments versus the nonheated treatments, which is far less than the expected respiration of $71 \%$ more with a $\mathrm{Q}_{10}$ of 2.7 and a temperature difference of $5.4{ }^{\circ} \mathrm{C}$. However, the fine-roots $(<1 \mathrm{~mm})$ respired at 111 and $211 \%$ more on the heated and non-heated plots for the $10-30$ and $30-50 \mathrm{~cm}$ soil depths, respectively. As a result, at the ecosystem level, there was $61 \%$ more $\mathrm{C}$ being released to the atmosphere from the heated plots for the approximate $+5{ }^{\circ} \mathrm{C}$ differential in soil temperature. Such a response to a warmer climate could reduce C availability for other uses, including aboveground woody increment if other adjustments cannot be made. 


\section{Tables and Figures}

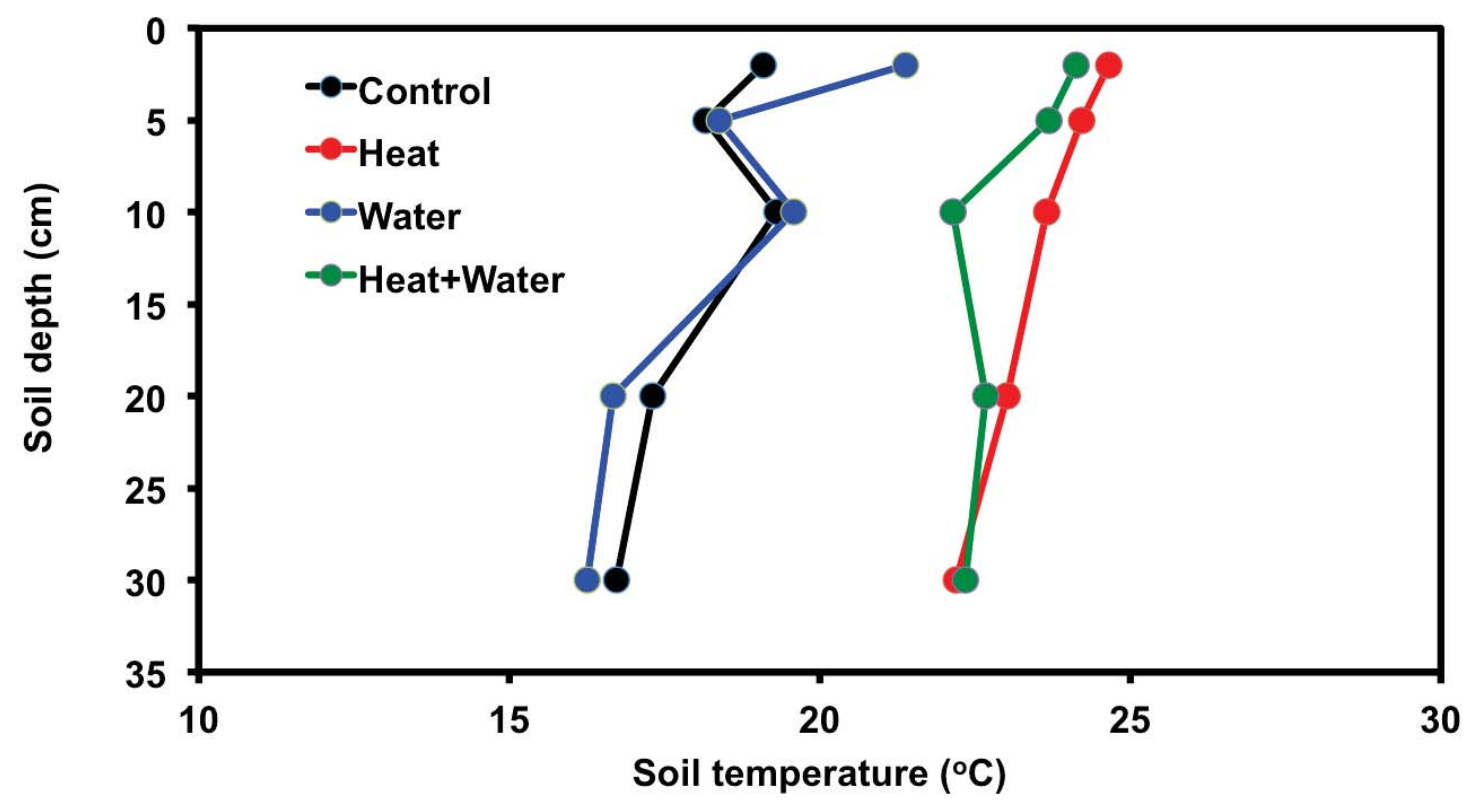

Figure 3.1 Temperature differences with depth for heated and non-heated treatments in August 2014. . 
Table 3.1 Analysis of variance (ANOVA) table for effects of soil warming and moisture addition on specific root respiration rates by root diameter class and soil depth increment at ambient soil temperature and at an $18{ }^{\circ} \mathrm{C}$ reference temperature. Significance was set at alpha $=0.05$.

\begin{tabular}{|c|c|c|c|c|c|}
\hline & \multicolumn{5}{|c|}{ Ambient Temperature Root Respiration } \\
\hline & d.f. & Sum Sq & \multirow{2}{*}{$\frac{\text { Mean Sq }}{17.14}$} & \multirow{2}{*}{$\begin{array}{r}\text { F value } \\
34.876\end{array}$} & \multirow{2}{*}{$\frac{P \text { value }}{<0.001}$} \\
\hline Heat & 1 & 17.14 & & & \\
\hline Water & 1 & 0.73 & 0.73 & 1.479 & 0.228 \\
\hline Root diameter & 2 & 79.01 & 39.50 & 80.396 & $<0.001$ \\
\hline Soil Depth & 2 & 33.34 & 16.67 & 33.922 & $<0.001$ \\
\hline Heat & 1 & 0.39 & 0.39 & 0.789 & 0.378 \\
\hline diameter & 2 & 5.78 & 2.89 & 5.880 & 0.005 \\
\hline Water x Root Diameter & 2 & 0.93 & 0.47 & 0.947 & 0.393 \\
\hline Heat & 2 & 0.60 & 0.30 & 0.610 & 0.546 \\
\hline Wa & 2 & 1.50 & 0.75 & 1.525 & 0.226 \\
\hline Soil depth & 3 & 18.19 & 4.55 & 9.256 & $<0.001$ \\
\hline meter & 2 & 0.22 & 0.11 & 0.225 & 0.799 \\
\hline Hea & 2 & 0.40 & 0.20 & 0.406 & 0.668 \\
\hline oil Depth & 4 & 0.61 & 0.15 & 0.313 & 0.868 \\
\hline Wa: & 4 & 1.07 & 0.27 & 0.545 & 0.704 \\
\hline oil depth & 3 & 1.21 & 0.40 & 0.821 & 0.487 \\
\hline & 63 & 30.96 & 0.49 & & \\
\hline & \multicolumn{5}{|c|}{ Reference Temperature Root Respiration } \\
\hline & d.f. & Sum Sq & Mean Sq & F value & $P$ value \\
\hline Heat & 1 & 1.36 & 1.36 & 3.118 & 0.082 \\
\hline Water & 1 & 1.04 & 1.04 & 2.372 & 0.129 \\
\hline Root diam & 2 & 62.74 & 31.37 & 71.771 & $<0.001$ \\
\hline Soil Dep & 2 & 34.75 & 17.37 & 39.750 & $<0.001$ \\
\hline Heat $x$ & 1 & 0.00 & 0.00 & 0.001 & 0.973 \\
\hline Hea & 2 & 0.56 & 0.28 & 0.635 & 0.533 \\
\hline ameter & 2 & 0.51 & 0.26 & 0.583 & 0.561 \\
\hline Heat & 2 & 2.28 & 1.14 & 2.608 & 0.082 \\
\hline Water x Soil depth & 2 & 1.49 & 0.74 & 1.701 & 0.191 \\
\hline Root diameter $x$ Soil depth & 4 & 22.09 & 5.52 & 12.635 & $<0.001$ \\
\hline Heat x Wate & 2 & 0.44 & 0.22 & 0.507 & 0.605 \\
\hline Hea & 2 & 1.12 & 0.56 & 1.278 & 0.286 \\
\hline & 4 & 2.21 & 0.55 & 1.267 & 0.293 \\
\hline Water $x$ Root diameter $x$ Soil depth & 4 & 1.77 & 0.44 & 1.010 & 0.409 \\
\hline $\begin{array}{l}\text { Heat } \times \text { Water } \times \text { Root diameter } \times \text { Soil depth } \\
\text { Residuals }\end{array}$ & $\begin{array}{r}3 \\
63\end{array}$ & $\begin{array}{r}0.39 \\
27.54\end{array}$ & $\begin{array}{l}0.13 \\
0.44\end{array}$ & 0.299 & 0.826 \\
\hline
\end{tabular}




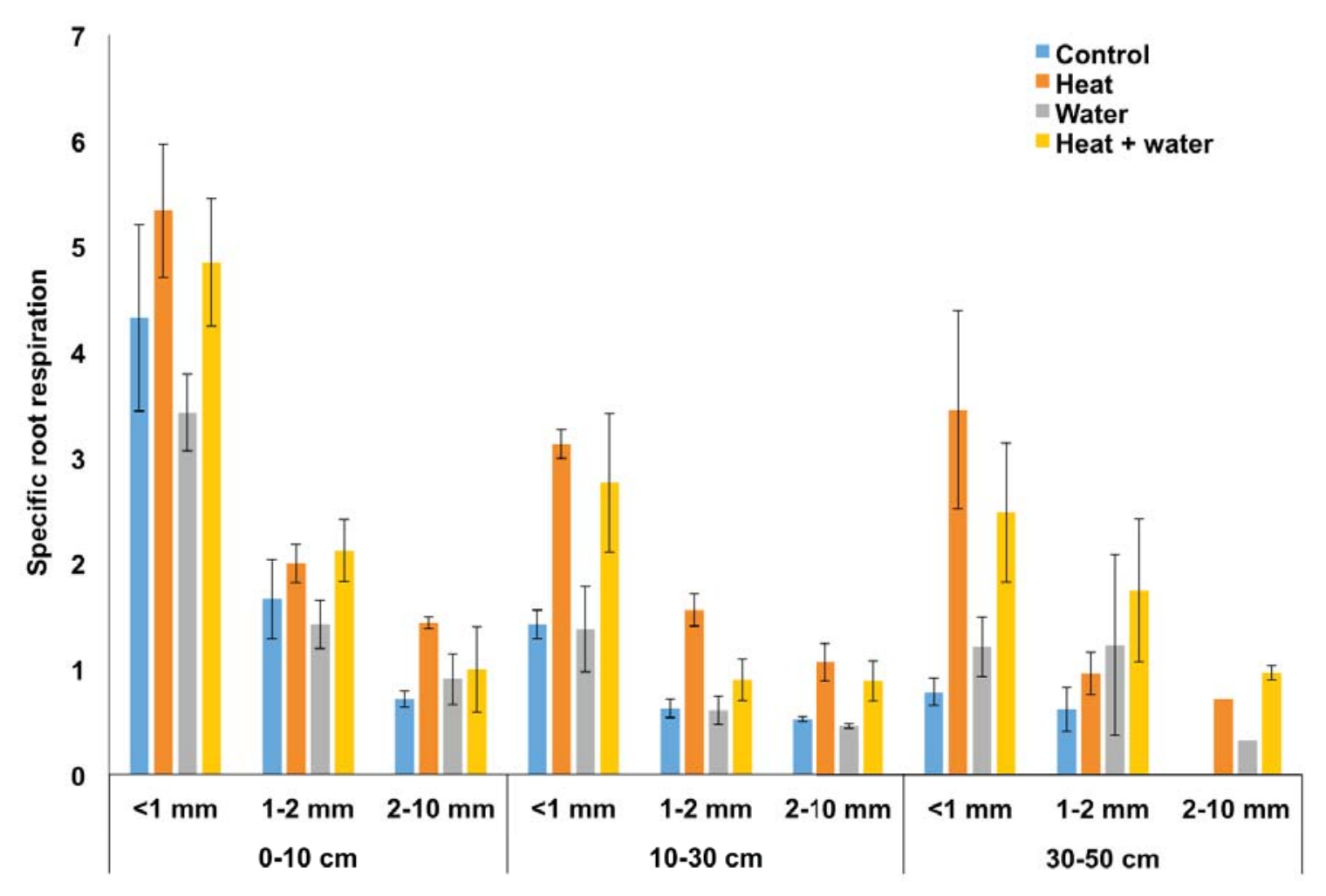

Figure 3.2 Average specific respiration ( $\mathrm{nmol} \mathrm{CO}_{2} \mathrm{~g}^{-1} \mathrm{~s}^{-1}$ ) at ambient soil temperature $\left(16.4^{\circ} \mathrm{C}\right.$ and $21.8^{\circ} \mathrm{C}$ for the non-heated and heated treatments respectively). Respiration is categorized by soil depth increment $(0-10,10-30$, and $30-50 \mathrm{~cm})$ and root diameter class $(<1,1-2,2-10 \mathrm{~mm})$. Error bars are one standard error of the mean. 


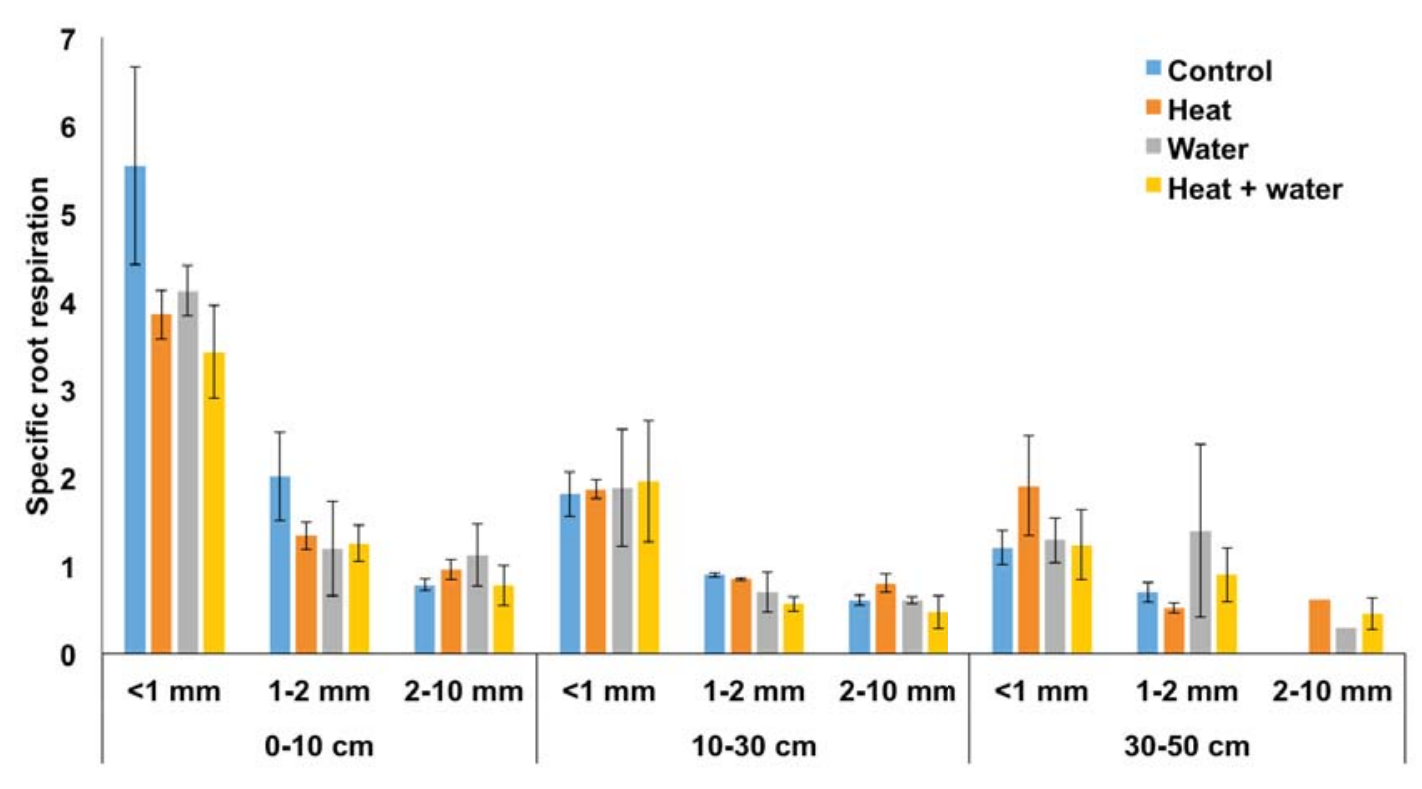

Figure 3.3 Average specific respiration $\left(\mathrm{nmol} \mathrm{CO}_{2} \mathrm{~g}^{-1} \mathrm{~s}^{-1}\right)$ at a common reference temperature of $18{ }^{\circ} \mathrm{C}$. Respiration is categorized by soil depth increment $(0-10,10-30$, and $30-50 \mathrm{~cm})$ and root diameter class $(<1,1-2,2-10 \mathrm{~mm})$. Error bars are one standard error of the mean. 
Table 3.2 Analysis of variance (ANOVA) table for effects on root biomass of soil warming and water addition, by root diameter class and soil depth increment.

Significance was set at alpha $=0.05$.

\begin{tabular}{|c|c|c|c|c|c|}
\hline & d.f. & Sum Sq & $\begin{array}{l}\text { Mean } \\
\text { Sq }\end{array}$ & $\begin{array}{l}\mathrm{F} \\
\text { value }\end{array}$ & $\begin{array}{l}P \\
\text { value }\end{array}$ \\
\hline Heat & 1 & 82839 & 82839 & 1.148 & 0.285 \\
\hline Water & 1 & 135975 & 135975 & 1.884 & 0.171 \\
\hline Root diameter & 2 & 1589823 & 794911 & 11.013 & $<0.001$ \\
\hline Soil Depth & 2 & 1073396 & 536698 & 7.435 & $<0.001$ \\
\hline Heat $x$ Water & 1 & 4003 & 4003 & 0.055 & 0.814 \\
\hline Heat $x$ Root diameter & 2 & 93859 & 46929 & 0.650 & 0.523 \\
\hline Water $x$ Root Diameter & 2 & 47595 & 23797 & 0.330 & 0.719 \\
\hline Heat $x$ Soil depth & 2 & 248646 & 124323 & 1.722 & 0.180 \\
\hline Water $\times$ Soil depth & 2 & 105491 & 52745 & 0.731 & 0.482 \\
\hline $\begin{array}{l}\text { Root diameter } \times \text { Soil depth } \\
\text { Heat } \times \text { Water } \times \text { Root }\end{array}$ & 4 & 844748 & 211187 & 2.926 & 0.021 \\
\hline diameter & 2 & 52673 & 26336 & 0.365 & 0.695 \\
\hline $\begin{array}{l}\text { Heat } \times \text { Water } \times \text { Soil depth } \\
\text { Heat } \times \text { Root diameter } \times \text { Soil }\end{array}$ & 2 & 226163 & 113082 & 1.567 & 0.211 \\
\hline $\begin{array}{l}\text { Depth } \\
\text { Water x Root diameter x }\end{array}$ & 4 & 294956 & 73739 & 1.022 & 0.396 \\
\hline $\begin{array}{l}\text { Soil depth } \\
\text { Heat } \times \text { Water } \times \text { Root }\end{array}$ & 4 & 123808 & 30952 & 0.429 & 0.788 \\
\hline diameter $\times$ Soil depth & 4 & 504051 & 126013 & 1.746 & 0.134 \\
\hline Residuals & 288 & 20788156 & 72181 & & \\
\hline
\end{tabular}




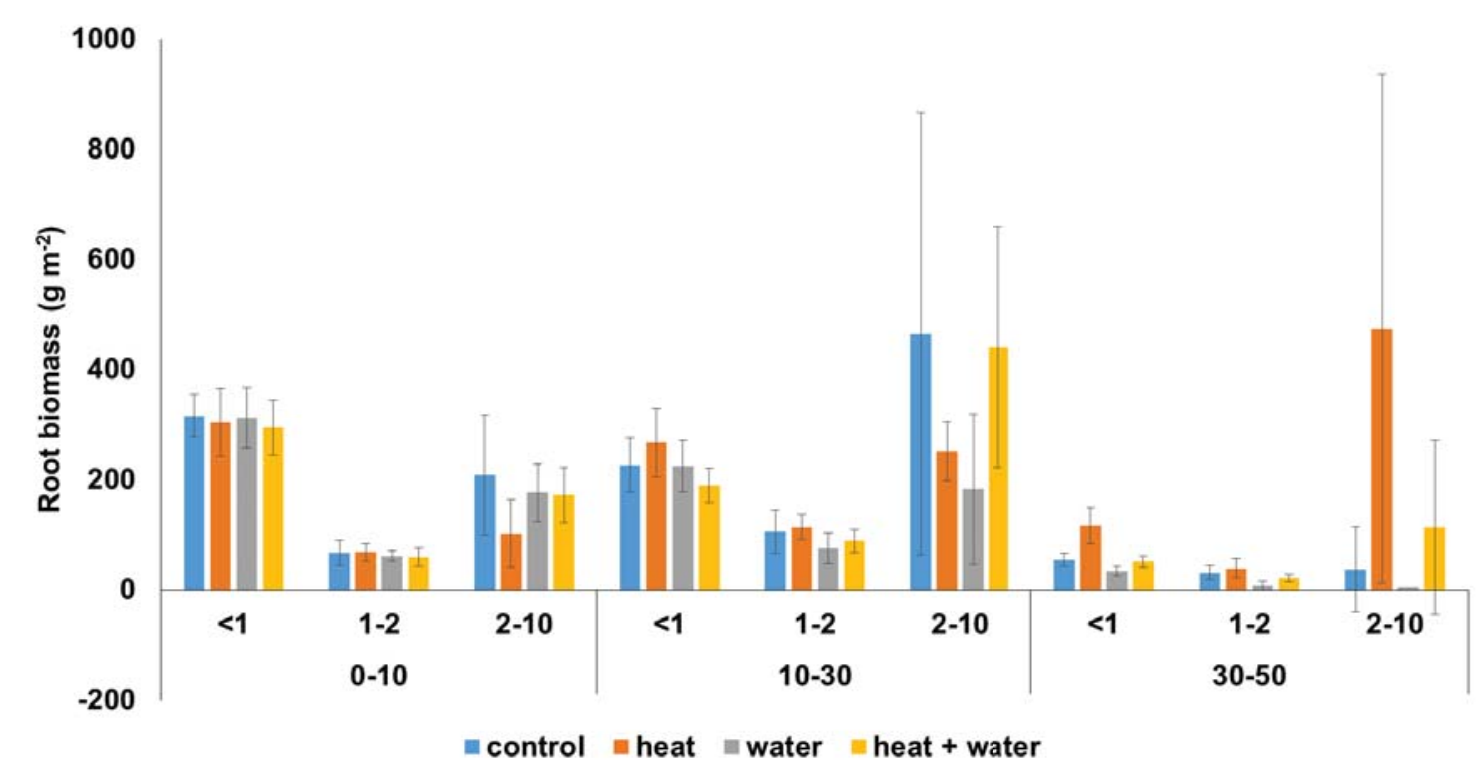

Figure 3.4 Average root biomass across treatments and root diameters for depth increments of 0-10 cm, 10-30 cm, and 30-50 cm. Error bars are standard error of the mean.

Table 3.3 Average ecosystem root respiration $\left(\mu \mathrm{mol} \mathrm{CO}_{2} \mathrm{~m}^{-2} \mathrm{~s}^{-1}\right)$ across treatments and soil depths with one standard error of then mean within parentheses.

\begin{tabular}{lcccc}
\hline \multirow{2}{*}{ Treatment } & \multicolumn{3}{c}{ Soil depth $(\mathrm{cm})$} & \multirow{2}{*}{ Total } \\
\cline { 2 - 4 } & $0-10$ & $10-30$ & $30-50$ & \\
\hline Control & $1.55(0.21)$ & $0.63(0.27)$ & $0.06(0.02)$ & $2.24(0.50)$ \\
Heat & $1.82(0.59)$ & $1.30(0.55)$ & $0.74(0.10)$ & $3.86(1.24)$ \\
Water & $1.33(0.41)$ & $0.46(0.21)$ & $0.06(0.02)$ & $1.85(0.64)$ \\
Heat + Water & $1.61(0.34)$ & $0.88(0.22)$ & $0.31(0.19)$ & $2.80(0.75)$ \\
\hline
\end{tabular}


Table 3.4 Average fine-root biomass $\left(<1 \mathrm{~mm}^{-\mathrm{g} \mathrm{m}^{-2}}\right)$ for the soil depth increments of 0 $10,10-30,30-50 \mathrm{~cm}$ across experimental soil treatments with standard error of the mean in parentheses.

\begin{tabular}{lccl}
\hline & \multicolumn{3}{c}{ Root biomass $\left(\mathrm{g} \mathrm{m}^{-2}\right)$} \\
\cline { 2 - 4 } Treatment & $0-10 \mathrm{~cm}$ & $10-30 \mathrm{~cm}$ & \multicolumn{1}{c}{$30-50 \mathrm{~cm}$} \\
\hline Control & $316(38)$ & $227(49)$ & $55(12)$ \\
Heat & $304(62)$ & $267(63)$ & $117(32)$ \\
Water & $311(55)$ & $225(47)$ & $34(9)$ \\
Heat + water & $295(50)$ & $190(31)$ & $51(11)$ \\
\hline
\end{tabular}

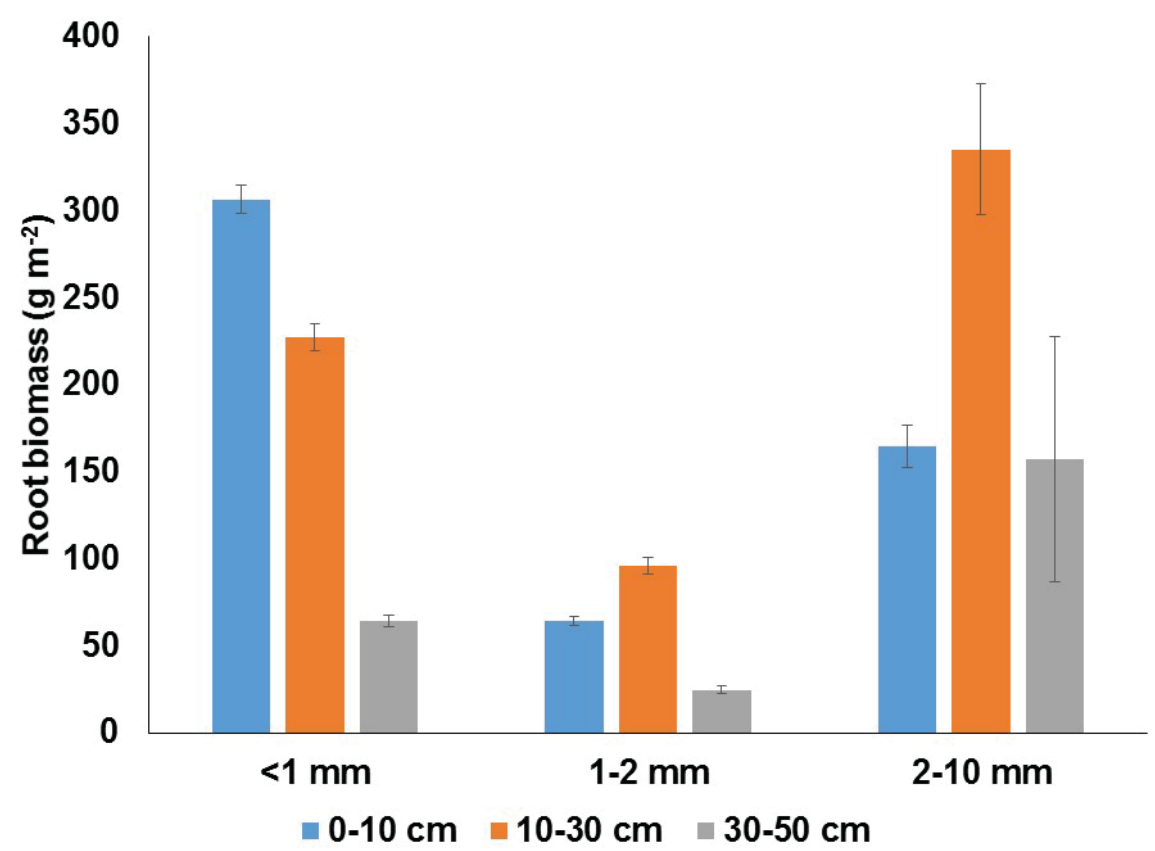

Figure 3.5 Average root biomass across soil depths of $0-10,10-30$, and $30-50 \mathrm{~cm}$ and root diameters of $<1,1-2$, and 2-10 $\mathrm{mm}$. Error bars are standard error of the mean. 


\section{References}

Alley R., et al. (2007). Climate Change 2007: The physical scientific basis, summary for policy makers (Cambridge University Press, New York).

Atkin O.K., Holly C., Ball M.C. (2000). Acclimation of snow gum (Eucalyptus pauciflora) leaf respiration to seasonal and diurnal variations in temperature: the importance of changes in the capacity and temperature sensitivity of respiration. Plant, Cell and Environment. 23:15-26.

Burton A.J., Jarvey J.C., Jarvi M.P., Zak D.R., Pregitzer K.S. (2012). Chronic N deposition alters root respiration-tissue $\mathrm{N}$ relationship in northern hardwood forests. Global Change Biology 18:258-266.

Canadell J.G., Quere C.L., Raupach M.R., Field C.B., Buitenhuis E.T., Ciais P., Conway T.J., Gillett N.P., Houghton R.A., Marland G. (2007). Contributions to accelerating atmospheric $\mathrm{CO}_{2}$ growth from economic activity, carbon intensity, and efficiency of natural sinks. Proceedings of the National Academy of Science USA. 104: 18866-18870.

Dixon R.K., Brown S., Houghton R.A., Solomon A.M., Texler M.C., Wisniewski J. (1994). Carbon pools and fluxes of global forest ecosystems. Science. 263: 185-190.

Finér L., Helmisaari H.S., Lõhmus K., Majdi H., Brunner I., Børja I., Eldhuset E., Godbold D. et al. (2007). Variation in fine root biomass of three European tree species: Beech (Fagus sylvatica L.), Norway spruce (Picea abies L. Karst.) and Scots pine (Pinus sylvestris L.). Plant Biosystems. 141: 394-405.

Giardina C.P., Coleman M.D., Hancock J.E., King J.S., Lilleskov E.A., Loya W.M., Pregitzer K.S., Ryan M.G., Trettin C.C. (2005). The response of belowground carbon allocation in forests to global change. Tree Species Effects on Soils: Implications for Global Change (eds D. Binkley \& O. Menyailo), pp. 119-154. NATO Science Series, Kluwer Academic Publishers, Dordrecht.

Goodale C.L., Apps M.J., Birdsey R.A., Field C.B., Heath L.S., Houghton R.A., Jenkins J.C., Kohlmaier G.H., Kurz W., Liu S., Nabuurs G., Nilsson S., Shvidenko A.Z. (2002). Forest carbon sinks in the Northerm Hemisphere. Ecological Applications. 12: 891-899.

Helmisaari H.S., Derome J., Nöjd P., Kukkola M. (2007). Fine root biomass in relation to site and stand characteristics in Norway spruce and Scots pine stands. Tree Physiology. 27: 1493-1504.

Henrick R.L., Pregitzer K.S. (1993). The dynamics of fine root length, biomass, and nitrogen content in two northern hardwood ecosystems. Canadian Journal of Forest Research. 23: 2507-2520.

Jarvi M.P., Burton A.J. (2013). Acclimation and soil moisture constrain sugar maple root respiration in experimentally warmed soil. Tree physiology 33(9):949-959. 
Jurgensen M.F., Larsen M.J., Harvey A.E.. 1977. A soil sampler for steep, rocky sites. USDA Forest Service Research Notes INT-RN-217.

Karl T., Melillo J., Peterson T., Hassol S.J. (2009). Global climate change impacts in the United States: a state of knowledge report from the US global change research program. Cambridge: Cambridge University Press.

Kratz C.J. (2014). Impacts of climate change on soil microorganisms in northern hardwood forests. PhD Dissertation. Michigan Technological University.

Lambers H., Chapin F.S., Pons T.L. (2008). Plant physiological ecology. New York, NY, USA: Springer.

Litton C.M., Giardina C.P. (2008). Below-ground carbon flux and partitioning: global patterns and response to temperature. Functional Ecology. 22: 941-954.

Litton C.M., Raich J.W., Ryan M.G. (2007). Review: carbon allocation in forest ecosystems. Global Change Biology. 13: 2089-2109.

McCormack M.L., Dickie I.A., Eissenstat D.M., Fahey T.J., Fernandez C.W., Guo D., ... \& Zadworny M. (2015). Redefining fine roots improves understanding of below-ground contributions to terrestrial biosphere processes. New Phytologist.

Meier I.C., Leuschner C. (2008). Belowground drought response of European beech: fine root biomass and carbon partitioning in 14 mature stands across a precipitation gradient. Global Change Biology. 14: 1-15.

Melillo J.M., Butler S., Johnson J., Mohan J., Steudler P., Lux H., Burrows E., Bowles F., Smith R., Scott L., Vario C., Hill T., Burton A., Zhou Y., Tang J. (2011). Soil warming, carbon-nitrogen interactions, and forest carbon budgets. Proceedings of the National Academy of Science. 108(23): 9508-9512.

Melillo J.M., Callaghan T.V., Woodward F.I., Salati E., Sinha E.S.K. (1990). Effect on ecosystems in climate change: The IPCC Scientific Assessment, eds Houghton JT, Jenkins GJ, Ephraums JJ (Cambridge University Press, New York), pp 283-310.

Melillo J.M., Kicklighter D.W., McGuire A.D., Peterjohn W.T., Newkirk K. (1995). Global change and its effects on soil organic carbon stocks. Report of the Dahlem Workshop on the Role of Nonliving Organic Matter in the Earth's Carbon Cycle, eds Zepp R, Sonntag C (John Wiley \& Sons, Oxford), pp 175-189.

Pregitzer K.S., Laskowski M.J., Burton A.J., Lessard V.C., Zak D.R. (1998). Variation in sugar maple root respiration with root diameter and soil depth. Tree physiology, 18(10), 665-670.

R Development Core Team. (2008). R: A language and environment for statistical computing. R Foundation for Statistical Computing, Vienna, Austria. ISBN 3-900051-07- 
0, URL http://www.R-project.org.

Schimel D.S., Braswell B.H., Holland E.A., McKeown R., Ojima D.S., Painter T.H., Parton W.J., Townsend A.R. (1994). Climatic, edaphic, and biotic controls over storage and turnover of carbon in soils. Global Biogeochemical Cycles. 8: 279-293.

Shaver G.R., et al. 2000. Global warming and terrestrial ecosystems: A conceptual framework for analysis. Bioscience. 50: 871-882.

Xia M., Guo D., Pregitzer K. S. (2010). Ephemeral root modules in Fraxinus mandshurica. New Phytologist, 188(4), 1065-1074. 


\title{
Chapter 4: Ecosystem root respiration in sugar maple forests increases with temperature within populations but not across populations: Results of a range-wide study ${ }^{1}$
}

\begin{abstract}
Plant respiration returns more $\mathrm{C}$ to the atmosphere than the combustion of fossil fuels by almost an order of magnitude. How plant respiration will respond and adjust to future climate change across species entire native range is uncertain. Many current ecosystem and earth systems models allow respiration to increase with temperature, often using an exponential response. This study was conducted across the latitudinal range of sugar maple (Acer saccharum Marsh.) in the Midwest U.S., spanning approximately 10 degrees of latitude and $10{ }^{\circ} \mathrm{C}$ of mean annual temperature, to determine if such a temperature response applied both within and across sites. Fine-root respiration was measured at sixteen different locations three times during the growing season of 2014 (June, July, and September). Fine-root biomass and fine-root $\mathrm{N}$ concentration were also determined. Specific fine-root respiration increased with temperature within each location, but across sites there was relatively greater specific fine-root respiration at the northern, cooler sites than at the southern, warmer sites, leading to negative correlations between respiration and temperature across sites for two of the sample periods. Fine-root biomass and fineroot $\mathrm{N}$ concentration were also lower at these southern, warmer sites. Overall, ecosystem fine-root respiration $\left(\mu \mathrm{mol} \mathrm{CO} \mathrm{CO}^{-2} \mathrm{~s}^{-1}\right)$ rates were greater at the northern sites than the southern sites. It is not known if the observed differences in root respiration, $\mathrm{N}$ concentration, and biomass among populations in response to temperature regime are a plastic response of which all sugar maple are capable, or if there are inherent temperature races within sugar maple that would not allow this tree species to make such large adjustments at individual locations across its native range to future climate change. However, the lack of changes in root $\mathrm{N}$ and biomass during four years of experimental soil warming at one of the sites, suggests inherent differences among populations are likely responsible for much of the observed patterns across the broad geographic region and only a limited degree of acclimation may be possible within local populations.
\end{abstract}

${ }^{1}$ The material contained in this chapter has not been submitted to any journal yet. Mickey Jarvi is the sole contributor in designing the experiment, collecting data, analyzing and interpreting data, and writing the manuscript. Andrew Burton will be listed as a coauthor when the manuscript is submitted to a future journal. 


\section{Introduction}

Globally, plants fix approximately $120 \mathrm{Pg} \mathrm{C}_{\mathrm{Cear}}{ }^{-1}$ through photosynthesis (Prentice et al. 2001), but concurrently use much of this newly acquired photosynthate to conduct cellular respiration associated with building new tissue, maintaining and repairing existing tissue, and transporting ions throughout the plant's tissues. Plant respiration $\left(\mathrm{R}_{\mathrm{a}}\right)$ releases about 45-60 Pg C to the atmosphere every year (Atkin and Tjoelker 2003; Luyssaert et al. 2007; Prentice et al. 2001), which is approximately 6-8 times the amount of $\mathrm{C}$ released to the atmosphere as fossil fuel combustion (IPCC 2013a; Piao et al. 2010). Since $R_{a}$ is enzymatically driven, it often has been found to exponentially increase with temperature (Jarvi and Burton 2013; Jarvi 2011; Piao et al. 2010; Ryan et al. 1997; Tjoelker et al. 2001). $\mathrm{R}_{\mathrm{a}}$ uses $30-80 \%$ of daily photosynthate (Atkin and Tjoelker 2003; Delucia et al. 2007; Litton et al. 2007; Luyssaert et al. 2007), thus increases in temperature could potentially cause greater respiration and return of $\mathrm{CO}_{2}$ to the atmosphere.

The Intergovernmental Panel on Climate Change (IPCC) predicts that the terrestrial portion of the planet will warm by 1 to $5^{\circ} \mathrm{C}$ by 2100 relative to 1850 to 1900 (IPCC 2013a), mainly due to increases of greenhouse gases such as $\mathrm{CO}_{2}$. Additionally, the Midwestern portion of the United States may see an increase in growing season temperatures of 2 to $5^{\circ} \mathrm{C}$ by 2100 , relative to 1986-2005 (IPCC 2013b). Precipitation patterns are predicted to change as well, as some portions of the planet will get drier, while others will be wetter (IPCC 2013b). Increases in global temperatures can affect the structure and function of a terrestrial ecosystems (Bond-Lamberty and Thomson 2010; 
Luo et al. 2001; Nemani et al. 2003; Petchey et al. 1999; Walker et al. 2006), and these changes can affect the $\mathrm{C}$ cycling in these systems. It is unclear if changes in $\mathrm{C}$ cycling in terrestrial ecosystems will have a positive or negative feedback on the Earth's climate (Cao and Woodward 1998; Cox et al. 2000; Davidson and Janssens 2006; Melillo et al. 2002; Smith and Fang 2010). Lu et al. (2013) suggest a better understanding of how ecosystem $\mathrm{C}$ cycling adjusts to a changing climate is needed to enable more accurate predictions of future $\mathrm{C}$ cycling.

Soil C efflux (autotrophic and heterotrophic respiration, $\mathrm{R}_{\mathrm{a}}$ and $\mathrm{R}_{\mathrm{h}}$ ) can contribute up to $60-80 \%$ of total ecosystem respiration, and $30-60 \%$ of this is root respiration (Bowden et al. 1993; Epron et al. 1999; Nakane et al. 1996; Pregitzer et al. 1998). Very fine-roots $(<0.5 \mathrm{~mm})$ of woody plants can contribute about $50 \%$ of ecosystem root respiration in temperate hardwood forests (Burton et al. 2012), thus their response to a warmer world could have a large impact on ecosystem C balance and feedbacks to atmospheric $\mathrm{CO}_{2}$ concentration and the rate of warming. When root tissues undergo a short-term increase in temperature, they exhibit an exponential increase in respiration with a $\mathrm{Q}_{10}$ of 1.8 - 3.0 (Burton et al. 2002; Piao et al. 2010). With climatic warming, the associated potential increase in photosynthate usage by root respiration might result in decreased $\mathrm{C}$ availability for biomass production and an increase in return of assimilate to the atmosphere as soil $\mathrm{CO}_{2}$ efflux, potentially creating a positive feedback loop causing even higher global temperatures (Woodwell and Mackenzie 1995).

Acclimation of tissue respiration to changes in temperature would limit increases in $\mathrm{R}_{\mathrm{a}}$ and potential decreases in net primary productivity (NPP). Acclimation can either 
be accomplished by reducing metabolic capacity of existing tissues (Atkin and Tjoelker 2003) or by building new tissues that are less metabolically active (Loveys et al. 2003; Ow et al. 2008). The presence of acclimation has been found in foliage (Atkin et al. 2015, Slot and Kitajima 2015, Atkin et al. 2000a, b; Cooper 2004; Larigauderie and Körner 1995; Loveys et al. 2003, Vanderwel et al. 2015) and roots (Atkin et al. 2009; Atkin et al. 2000b; Atkinson et al. 2007; Covey-Crump et al. 2002; Edwards et al. 2004), but the data for roots is limited largely to herbaceous plants and seedlings. Additionally, the mechanisms for acclimation in roots to changes in temperature are unknown, but are assumed to be changes in enzymatic capacity, substrate limitation, and/or adenylate control (Atkin and Tjoelker 2003). In addition to tissue-level physiological changes, reductions in fine-root biomass can also constrain ecosystem level root respiration, as was observed in a long-term soil warming study in a temperature hardwood forest (Melillo et al. 2011) at Harvard Forest. This adjustment in conjunction with increases in $\mathrm{N}$ mineralization allowed NPP to actually increase.

Current experimental warming studies in mature natural forests do not include total tree warming due to logistical and economic constraints. Instead soil warming is applied using buried heating cables (Melillo et al. 2011) or infra-red heating lamps from above (Jarvi and Burton 2013; Jarvi 2011). Since such studies do not warm the entire ecosystem and can be limited in duration, comparing their detailed responses to findings from transect studies, which look at common plant or tree species across a natural temperature gradient, should help us understand if experimental warming responses 
measured at one location are likely to apply across a species' entire range and if they play a role in governing the current range and function of a species.

Jarvi and Burton (2013) found that there was indeed acclimation of surface fineroot respiration to temperature at an experimental warming study in northern Michigan on the heated plots versus the non-heated plots. There was not the expected $49-64 \%$ more respiration on the heated plots with a $4-5^{\circ} \mathrm{C}$ increase in temperature with a $\mathrm{Q}_{10}$ of 2.7. There was in fact only a $13-29 \%$ increase in respiration on the heated plots versus the non-heated plots after 2.5 years of warming. It was not known if the acclimation observed in this experiment (Jarvi and Burton 2013) is occurring across the temperature gradient of sugar maple's natural range, or if other mechanisms, inherent to local populations, constrain belowground $\mathrm{C}$ allocation to root respiration. This transect study was conducted with the purpose of comparing data obtained from the experimental warming site (Jarvi and Burton 2013) to that from sixteen sites located along a $10{ }^{\circ} \mathrm{C}$ natural gradient in mean annual temperature, spanning 10 degrees of latitude across sugar maple's native range.

The objectives of this study were to: 1) determine if differences in root respiration, root $\mathrm{N}$ concentration and/or root biomass exist along the transect and if such differences were related to differences in latitude and mean annual temperature, and 2) assess whether trends along the transect in root specific respiration and ecosystem respiration with temperature would be correctly estimated by current modeling methods.

The results of this comparison have potentially important implications for how to model responses to temperature. Root biomass, root N, and root respiration could vary 
across this transect due to either a general plastic response to site conditions that could occur anywhere within sugar maple's range if environmental conditions warranted or due to genetic differences among populations of sugar maple throughout its range.

\section{Methods}

\section{Sugar maple transect}

The transect encompassed the natural range of sugar maple (Acer saccharum Marsh.) in the central United States of North America and included sixteen sample locations spanning 10 degrees of latitude from $47^{\circ}$ in the north to $37^{\circ}$ in the south. (Figure 4.1, Table 4.1). The sites were selected to have overstory composition dominated by sugar maple. Mean annual temperature data from NOAA.org shows a 10.7 ${ }^{\circ} \mathrm{C}$ increase along the transect, from $2.3{ }^{\circ} \mathrm{C}$ in the north (TOFT site) to $13.0{ }^{\circ} \mathrm{C}$ in the south (SOSH site). Site locations were selected in June 2014 and tree species composition, dbh, trees per hectare, and basal area were determined using six $1 / 50$ ha plots per site (Table 4.1).

The site labeled SOSH is located at $37^{\circ} 35.3^{\prime} \mathrm{N}$ latitude and $89^{\circ} 26.1^{\prime} \mathrm{W}$ longitude, in the southern portion of the Shawnee National Forest in southern Illinois with a mean annual temperature (MAT) of $13.0^{\circ} \mathrm{C}$. The site's basal area is dominated by sugar maple with $71.9 \%$ of the $15.5 \mathrm{~m}^{2} \mathrm{ha}^{-1}$ total. The site has a density of 541.7 trees ha${ }^{1}$, is situated on a $30 \%$ slope with an aspect of $270^{\circ}$. Other species located at SOSH include: pawpaw (Asimina triloba (L.) Dunal), bitternut hickory (Carya cordiformis (Wangenh.) K. Koch), shagbark hickory (Carya ovata (Mill.) K. Koch), American beech 
(Fagus grandifolia Ehrh.), tuliptree (Liriodendron tulipifera L.), eastern hophornbeam (Ostrya viginiana (Mill.) K. Koch), northern red oak (Quercus rubra L.).

NOSH was located on the northern portion of the Shawnee National Forest at $37^{\circ}$ $40.8^{\prime} \mathrm{N} 89^{\circ} 23.9^{\prime} \mathrm{W}$ with a MAT of $13.0^{\circ} \mathrm{C}$. Sugar maple dominates the site's basal area with $73.1 \%$ of the $19.8 \mathrm{~m}^{2} \mathrm{ha}^{-1}$. This site has a density of 566.7 trees ha ${ }^{-1}$ and is located on a $45 \%$ slope at an aspect of $90^{\circ}$. Other species located at NOSH are: bitternut hickory (Carya cordiformis (Wangenh.) K. Koch), American beech (Fagus grandifolia Ehrh.), black walnut (Juglans nigra L.), tuliptree (Liriodendron tulipifera L.), white oak (Quercus alba L.), northern red oak (Q. rubra L.), sassafras (Sassafras albidum Nutt.).

The site SOHO was located on the southern portion of the Hoosier National Forest in southern Indiana at $38^{\circ} 3.1^{\prime} \mathrm{N} 86^{\circ} 31.3^{\prime} \mathrm{W}$ with a MAT of $11.7^{\circ} \mathrm{C}$. Sugar maple dominates the basal area at the site with $84.0 \%$ of the $18.6 \mathrm{~m}^{2} \mathrm{ha}^{-1}$. The site has a density of 566.7 trees ha- ${ }^{-1}$ and is located on a slope of $25 \%$ with an aspect of $340^{\circ}$. Other species at SOHO are: bitternut hickory (Carya cordiformis (Wangenh.) K. Koch), American beech (Fagus grandifolia Ehrh.), white ash (Fraxinus americana L.), tuliptree (Liriodendron tulipifera L.), eastern hophornbeam (Ostrya virginiana (Mill.) K. Koch.), black cherry (Prunus serotina Ehrh.), white oak (Quercus alba L.), northern red oak ( $Q$. rubra L.), sassafras (Sassafras albidum Nutt.), American elm (Ulmus americana L.).

The site $\mathrm{NOHO}$ was located on the northern portion of the Hoosier National Forest at $38^{\circ} 21.6^{\prime} \mathrm{N} 86^{\circ} 29.4^{\prime}$ with a MAT of $11.7^{\circ} \mathrm{C}$. Sugar maple dominates $93.2 \%$ of the $26.0 \mathrm{~m}^{2} \mathrm{ha}^{-1}$ of basal area. The site has a density of 516.7 trees ha ${ }^{-1}$ and is located on a $25 \%$ slope with an aspect of $95^{\circ}$. Other species located at NOHO are: shagbark 
hickory (Carya ovata (Mill.) K. Koch), American beech (Fagus grandifolia Ehrh.), white oak (Quercus alba L.), chestnut oak (Q. montana Willd.).

The CEIL site is located at Funk's Grove in Central Illinois at $40^{\circ} 21.1^{\prime} \mathrm{N} 89^{\circ}$ $7.8^{\prime} \mathrm{W}$ with a MAT of $10.4{ }^{\circ} \mathrm{C}$. Sugar maple dominates the site with $99.7 \%$ of the 40.9 $\mathrm{m}^{2} \mathrm{ha}^{-1}$ of basal area. The site's density was 758.3 trees ha ${ }^{-1}$ and is located on a $4 \%$ slope with an aspect of $210^{\circ}$. The other species included at CEIL were: American elm (Ulmus americana L.).

The NOIN site was located in northeastern Illinois on Illinois Nature Preserves Commission land at $41^{\circ} 24.4^{\prime} \mathrm{N} 87^{\circ} 35.8^{\prime} \mathrm{W}$ with a MAT of $9.6^{\circ} \mathrm{C}$. Sugar maple dominates the basal area at the site with $91.6 \%$ of the $24.5 \mathrm{~m}^{2} \mathrm{ha}^{-1}$. The density at the site was 791.7 trees $\mathrm{ha}^{-1}$ on a $10 \%$ slope with an aspect of $10^{\circ}$. Other species at NOIN include: bitternut hickory (Carya cordiformis (Wangenh.) K. Koch), black walnut (Juglans nigra L.), eastern hophornbeam (Ostrya virginiana (Mill.) K. Koch), black cherry (Prunus serotina Ehrh.), white oak (Quercus alba L.), northern red oak (Q. rubra L.).

NOIL was located in northern Illinois on Illinois Nature Preserves Commission land at $41^{\circ} 51.2^{\prime} \mathrm{N} 89^{\circ} 20.7^{\prime} \mathrm{W}$ with a MAT of $9.0^{\circ} \mathrm{C}$. Sugar maple dominates the basal area with $73.5 \%$ of the $14.4 \mathrm{~m}^{2} \mathrm{ha}^{-1}$. The tree density was 966.7 trees ha ${ }^{-1}$ and is located on a $25 \%$ slope with an aspect of $270^{\circ}$. Other species located at NOIL include: bitternut hickory (Carya cordiformis (Wangenh.) K. Koch), black walnut (Juglans nigra L.), eastern hophornbeam (Ostrya virginiana (Mill.) K. Koch), black cherry (Prunus 
serotina Ehrh.), northern red oak (Quercus rubra L.), American elm (Ulmus americana L.).

OCNA was located on the Manistee National Forest in southern lower Michigan at $43^{\circ} 40.2^{\prime} \mathrm{N} 86^{\circ} 8.6^{\prime} \mathrm{W}$ with a MAT of $7.2^{\circ} \mathrm{C}$. Sugar maple dominates $71.1 \%$ of the $38.3 \mathrm{~m}^{2} \mathrm{ha}^{-1}$ of basal area. The density was 575.9 trees ha $^{-1}$ and located on a slope of $5 \%$ and an aspect of $330^{\circ}$. Other species at OCNA were: red maple (Acer rubrum L.), American beech (Fagus grandifolia Ehrh.), white ash (Fraxinus americana L.), eastern hophornbeam (Ostrya virginiana (Mill.) K Koch), black cherry (Prunus serotina Ehrh.), northern red oak (Quercus rubra L.), eastern hemlock (Tsuga canadensis (L.) Carr.).

WXLO was located in the Manistee National Forest in central lower Michigan at $44^{\circ} 22.8^{\prime} \mathrm{N} 85^{\circ} 50.0^{\prime} \mathrm{W}$ with a MAT of $5.9^{\circ} \mathrm{C}$. Sugar maple dominated the basal area with $78.8 \%$ of the $33.7 \mathrm{~m}^{2} \mathrm{ha}^{-1}$. The tree density was 542.6 trees ha $\mathrm{h}^{-1}$ on a slope of $10 \%$ and aspect of $30^{\circ}$. Other species present at WXLO were: red maple (Acer rubrum L.), American beech (Fagus grandifolia Ehrh.), black cherry (Prunus serotina Ehrh.), and northern red oak (Quercus rubra L.).

CEWI was located at Big Eau Pleine Woods State Natural Area in central Wisconsin at $44^{\circ} 44.3^{\prime} \mathrm{N} 89^{\circ} 50.5^{\prime} \mathrm{W}$ with a MAT of $4.3^{\circ} \mathrm{C}$. The basal area was dominated by sugar maple with $84.6 \%$ of the $37.6 \mathrm{~m}^{2} \mathrm{ha}^{-1}$. The density was 583.3 trees $\mathrm{ha}^{-1}$ on a slope of $5 \%$ and aspect of $25^{\circ}$. Other species located at CEWI included: yellow birch (Betula alleghaniensis Britton), bitternut hickory (Carya cordiformis (Wangenh.) K. Koch), green ash (Fraxinus pennsylvanica Marsh.), eastern hophornbeam (Ostrya virginiana (Mill.) K. Koch). 
The site PELL was located on the Mackinaw State Forest in northern lower Michigan at $45^{\circ} 32.8^{\prime} \mathrm{N} 84^{\circ} 51.6^{\prime} \mathrm{W}$ with a MAT of $5.9^{\circ} \mathrm{C}$. The basal area was dominated by sugar maple with $88.8 \%$ of the $33.7 \mathrm{~m}^{2} \mathrm{ha}^{-1}$. The density was 529.6 trees $\mathrm{ha}^{-1}$ on a slope of $10 \%$ and aspect of $10^{\circ}$. Other species included at PELL were: red maple (Acer rubrum L.), American beech (Fagus grandifolia Ehrh.), white ash (Fraxinus americana L.), American basswood (Tilia americana L.).

NOWI was located on Wisconsin Department of Natural Resources land in northern Wisconsin at $46^{\circ} 15.2^{\prime} \mathrm{N} 90^{\circ} 36.8^{\prime} \mathrm{W}$ with a MAT of $4.3^{\circ} \mathrm{C}$. Basal area was dominated by sugar maple with $93.2 \%$ of the $30.8 \mathrm{~m}^{2} \mathrm{ha}^{-1}$. The density was 725.0 tree $\mathrm{ha}^{-1}$ on a slope of $5 \%$ and aspect of $30^{\circ}$. Other species included at NOWI were: balsam fir (Abies balsamea (L.) Mill.), paper birch (Betula papyrifera Marsh.), white ash (Fraxinus americana L.), eastern hophornbeam (Ostrya virginiana (Mill.) K. Koch.), white spruce (Picea glauca (Moench) Voss), American basswood (Tilia americana L.).

The FORD site was located on the Michigan Technological University's Ford Center and Forest in western upper Michigan at $46^{\circ} 38.4^{\prime} \mathrm{N} 88^{\circ} 29.1^{\prime}$ 'W with a MAT of $3.9^{\circ} \mathrm{C}$. The basal area was dominated by sugar maple with $89.3 \%$ of the $21.7 \mathrm{~m}^{2} \mathrm{ha}^{-1}$. Tree density was 963.0 trees $\mathrm{ha}^{-1}$ on a slope of $5 \%$ and aspect of $270^{\circ}$. Other species at FORD include: yellow birch (Betula alleghaniensis Britton), eastern hophornbeam (Ostrya virginiana (Mill.) K. Koch.), eastern hemlock (Tsuga canadensis (L.) Carr.), American elm (Ulmus americana L.).

ALBT was located on Copper Country State Forest land in western upper Michigan at $46^{\circ} 51.7^{\prime} \mathrm{N} 88^{\circ} 53.0^{\prime} \mathrm{W}$ with a MAT of $3.9^{\circ} \mathrm{C}$. Sugar maple dominated 
$89.7 \%$ of the $36.4 \mathrm{~m}^{2} \mathrm{ha}^{-1}$ of basal area. Tree density was 574.1 trees ha ${ }^{-1}$ on a slope of $<$ 2\%. Other species present at ALBT were: red maple (Acer rubrum L.), balsam fir (Abies balsamea (L.) Mill.), yellow birch (Betula alleghaniensis Britton), eastern hophornbeam (Ostrya virginiana (Mill.) K. Koch), white spruce (Picea glauca (Moench) Voss), black cherry (Prunus serotina Ehrh.), American basswood (Tilia americana L.).

CANA was located at Turkey Lakes Watershed operated by the Great Lakes Forestry Centre in southern Ontario, Canada at $47^{\circ} 2.8^{\prime} \mathrm{N} 84^{\circ} 24.5^{\prime} \mathrm{W}$ with a MAT of $4.6^{\circ} \mathrm{C}$. The basal area was dominated by sugar maple with $87.0 \%$ of the $34.3 \mathrm{~m}^{2} \mathrm{ha}^{-1}$. Tree density was 733.3 trees ha ${ }^{-1}$ on a slope of $35 \%$ and aspect of $20^{\circ}$. The other species located at CANA was: yellow birch (Betula alleghaniensis Britton).

Finally, the TOFT site was located on the Superior National Forest in northern Minnesota at $47^{\circ} 41.1^{\prime} \mathrm{N} 90^{\circ} 44.2^{\prime} \mathrm{W}$ with a MAT of $2.3^{\circ} \mathrm{C}$. The basal area was dominated by sugar maple with $74.2 \%$ of the $29.1 \mathrm{~m}^{2} \mathrm{ha}^{-1}$. Tree density was 1066.7 trees $\mathrm{ha}^{-1}$ on a slope of $10 \%$ and aspect of $120^{\circ}$. Other species present at TOFT were: red maple (Acer rubrum L.), paper birch (Betula papyrifera Marsh.), and quaking aspen (Populus tremuloides Michx.).

\section{Root respiration}

Fine-root respiration was measured in June, July, and September of 2014. Six sampling locations were designated at each site for use in all sampling, with each of five exterior sampling locations placed within $20 \mathrm{~m}$ of a center sampling location. On each measurement date three $5 \mathrm{~cm}$ diameter $\mathrm{x} 10 \mathrm{~cm}$ deep soil cores per sampling location 
were used to gather samples for determining fine-root respiration. On all sample dates, root respiration measurements were made at the ambient soil temperature for the particular sample date and location, and at a common reference temperature of $18{ }^{\circ} \mathrm{C}$.

The comparison of root respiration rates across sites at a common reference temperature was used as an indicator of differences among sites and across time in root metabolic capacity, as a way to investigate acclimation. The roots were hand-cleansed of soil, and approximately $2 \mathrm{~g}$ fresh weight of fine roots $(<1 \mathrm{~mm})$ were collected for measurement of root respiration using infrared gas analyzers (IRGAs, Ciras-1 and Ciras-2, PP Systems, Haverhill MA). Root samples were placed inside aluminum cuvettes that extended into water baths to maintain desired sample temperature. The IRGAs were run in an open system configuration with an input $\mathrm{CO}_{2}$ concentration of $1000 \mu \mathrm{L} \mathrm{L}^{-1}$, designed to simulate surface soil atmosphere $\mathrm{CO}_{2}$ levels (Burton et al. 1997). Stable fine-root respiratory efflux rates were recorded after a 15 minute period that allowed roots to equilibrate to the cuvette temperature and effects of opening the cuvette to the atmosphere to subside. Additional details of the root respiration measurement technique can be found in Jarvi and Burton (2013).

\section{Root biomass}

In September 2014, samples were taken for determining root biomass at each location. To do this, all soil was retained from the three $5 \mathrm{~cm}$ by $10 \mathrm{~cm}$ cores per sampling location used for root respiration measurements from the depth increment of 0 $10 \mathrm{~cm}$ below soil surface and placed on ice. Additionally, six single $5 \mathrm{~cm}$ by $10 \mathrm{~cm}$ cores at a depth of 10-20 cm below the soil surface were collected to determine deeper root 
biomass. All cores were placed on ice and returned to the lab and stored at $-20^{\circ} \mathrm{C}$ until further analysis. Each soil core was weighed after thawing for total field weight, and then soil was passed through a $6.3 \mathrm{~mm}$ opening sieve. All rocks that did not pass this sieve were weighed for use in bulk density calculations. The soil was then passed through a $2.0 \mathrm{~mm}$ opening sieve. During sieving, all live tree roots (pliable and white to brown in color), regardless of diameter, were separated from the soil by hand, hand cleansed of soil particles, and stored at $-20{ }^{\circ} \mathrm{C}$. All debris and dead roots (brittle and black in color) were discarded. A subsample of soil free of rocks, debris, and roots was collected, its moist weight recorded, and then placed in a $65^{\circ} \mathrm{C}$ oven for 72 hours. Afterwards, the dry weight of this subsample were recorded for use in soil moisture and bulk density measurements. Root samples separated during sieving were cleansed in deionized water, sorted into one of four diameter classes $(<1,1-2,2-5$, and $>5 \mathrm{~mm})$, dried at $65^{\circ} \mathrm{C}$ for 48 hours, and weighed. The weights of fine roots used in the respiration measurements were added to the surface fine root biomass from the residual soil to determine total surface fine root biomass.

\section{Ecosystem fine-root respiration}

Ecosystem level fine-root respiration was calculated by using the root biomass measurements from September 2014 and the specific fine-root respiration measurements from all three sampling periods (June, July, and September 2014). Thus, fine-root

respiration ( $\left.\mathrm{nmol} \mathrm{CO} \mathrm{g}^{-1} \mathrm{~s}^{-1}\right)$ was multiplied by fine-root biomass $\left(\mathrm{g} \mathrm{m}^{-2}\right)$ and converted to $\mu \mathrm{mol} \mathrm{CO} \mathrm{Cm}^{-2} \mathrm{~s}^{-1}$ to obtain ecosystem level fine-root respiration. 


\section{$\operatorname{Root} N$}

Root $\mathrm{N}$ concentrations were determined from the fine-root respiration samples from June, July and September 2014. The dried root samples were ground and analyzed for $\mathrm{C}$ and $\mathrm{N}$ using an elemental analyzer (Carlo Erba NA $1500 \mathrm{NC}, \mathrm{CE}$ Elantech).

\section{Statistical Analysis}

All statistical analyses were conducted with R (R Core Team 2013). Pearson's correlation coefficient $(\mathrm{R})$ was used to assess correlations across sites of mean annual temperature with latitude, ambient soil temperature with latitude, and root biomass (by sample depth) and root $\mathrm{N}$ with latitude. Differences among sites and dates in fine-root respiration, ecosystem level-fine root respiration, and fine-root $\mathrm{N}$ were analyzed by repeated-measures analysis of variance (ANOVA) with fine-root respiration as the dependent variable, site location as the independent variable and date as the repeated measure. Differences in root biomass were assessed with 3-way ANOVA with root biomass assessed across site, soil depth increment, and root diameter.

\section{Results}

\section{Mean annual temperature and ambient soil temperature differences}

Mean annual temperature, with a range of $2.3-13.0^{\circ} \mathrm{C}$, was negatively correlated with latitude along the transect $\left(\mathrm{r}^{2}=0.97, \mathrm{R}=-0.98, P<0.001\right)$. The ambient surface soil temperature $(0-10 \mathrm{~cm})$ was strongly negatively correlated to increases in latitude across all three sample dates $\left(\mathrm{r}^{2}=0.61, \mathrm{R}=-0.78, P<0.001\right)$. The June, July, and 
September sampling periods had similar slopes of ambient soil temperature to latitude ( $P$ $=0.09)$ but different intercepts $(P<0.001)($ Figure 4.2). The June sample date had a range in ambient soil temperatures of $10.0^{\circ} \mathrm{C}\left(13.0-23.0^{\circ} \mathrm{C}\right.$, minimum to maximum respectively), the July date had a range of ambient soil temperatures of $8.9^{\circ} \mathrm{C}(11.9-$ $\left.20.8^{\circ} \mathrm{C}\right)$, and the September date had a range of soil temperatures of $9.8^{\circ} \mathrm{C}(9.1-18.9$ $\left.{ }^{\circ} \mathrm{C}\right)$ (Table 4.2, Figure 4.2).

\section{Specific fine-root respiration}

At ambient soil temperature specific fine-root respiration $\left(\mathrm{nmol} \mathrm{CO}_{2} \mathrm{~g}^{-1} \mathrm{~s}^{-1}\right)$ decreased significantly across sites with increases in temperature and decreases in latitude for the July and September dates (Figure 4.3). In contrast, within sites specific fine-root respiration always increased as soil temperature increased with temperature across dates (Table 4.4). Repeated-measures ANOVA indicated significant differences among sites in specific fine-root respiration across all sample dates at ambient soil temperature $(P<0.001$, Table 4.4). Additionally, there were significant differences among dates $(P<0.001$, Table 4.4) and a significant site $\mathrm{x}$ date interaction $(P<0.001$, Table 4.4).

Fine-root respiration at reference temperature $\left(18{ }^{\circ} \mathrm{C}\right)$ decreased significantly with increases in ambient soil temperature and decreases in latitude for all three sample dates $(P<0.001$, Figure 4.4, Table 4.4). Fine-root respiration at reference temperature also differed among dates $(P=0.018)$ and exhibited an interaction of site by date $(P=0.002$, Table 4.4). 


\section{Root biomass}

For the smallest diameter roots $(<1 \mathrm{~mm})$, root biomass was positively correlated to latitude at both the $0-10$ and $10-20 \mathrm{~cm}$ sampling depths $(\mathrm{R}=0.80, P<0.001$ and $\mathrm{R}=$ $0.55, P=0.03$ respectively, Table 4.5 , Figure $4.5 \& 4.6$ ), and negatively correlated with MAT. Three-way ANOVA suggests a significant difference in root biomass among sites $(P<0.001)$ and root diameter classes $(P<0.001)$, with site by root diameter $(P<0.001)$ and sample depth by root diameter $(P<0.001)$ interactions also occurring (Table 4.6, Figure $4.5 \& 4.6)$.

\section{Ecosystem fine-root respiration}

Ecosystem fine-root respiration $\left(\mu \mathrm{mol} \mathrm{CO} \mathrm{CO}^{-2} \mathrm{~s}^{-1}\right)$ is the product of specific fineroot respiration and fine-root biomass and is a measure of the contribution of fine-root respiration to soil $\mathrm{CO}_{2}$ efflux at these locations. Repeated measures ANOVA indicates significant differences among sites in ecosystem fine-root respiration $(P<0.001$, Table 4.7), with ecosystem fine-root respiration tending to decrease as ambient soil temperature increased across sites for all sample dates (Figure 4.7). There were also significant differences among sample dates in ecosystem fine-root respiration $(P<0.001$, Table 4.7), and a significant interaction with site location and sample date $(P<0.001$, Table 4.7 , Figure 4.7). Overall, ecosystem fine-root respiration tended to be higher in June and lowest in September (Figure 4.7), corresponding to differences in ambient soil temperature among sample periods.

\section{Fine-root $N$ concentration}


Fine-root $\mathrm{N}$ was negatively correlated to MAT and positively correlated to latitude of the sample sites $(\mathrm{R}=0.43, P<0.001)$ (Figure 4.8). The southern sites were lower in fine-root $\mathrm{N}$ than the northern sites across all three sample dates $(P<0.001)$ (Figure 4.8, Table 4.8).

\section{Discussion}

In many models, including coupled earth systems models used for predicting responses to climate change, plant tissue respiration is allowed to increase exponentially with temperature, often with a $\mathrm{Q}_{10}$ near 2 (Smith and Dukes 2013, Oleson et al. 2010, Tjoelker et al. 2001). Along this sugar maple transect, this would suggest that specific root respiration rates at ambient temperature would be at least $85 \%$ greater at the warmest transect site than at the coolest site. Instead, specific fine-root respiration at ambient temperature was greater for the coolest sites (northern latitudes), for the July (49\% greater) and September dates (27\% greater), and only $26 \%$ greater at the southern sites versus the northern sites in June (Figure 4.3, Table 4.4). Within sites; however, specific fine-root respiration always increased with ambient soil temperature across sample dates (Table 4.3), often with a $\mathrm{Q}_{10}$ near 2 to 3.

Fine root metabolic capacity was lower at the warmer, lower latitudes sites, as indicated by respiration rates at the reference temperature of $18^{\circ} \mathrm{C}$ (Figure 4.4, Table 4.4). These findings indicate that the sugar maple absorptive fine roots of the lower latitudes are less active at a given temperature than those from the cooler and more northern latitudes. Under field conditions, warmer temperatures cause respiration rates to 
be more similar among sites, likely indicating generally similar allocation of carbohydrates to perform work associated with fine root activity (i.e. nutrient uptake and transport).

These differences among sites in root metabolic capacity appear related to the construction of fine roots with lower $\mathrm{N}$ concentrations at the warmer, lower latitude sites (Figure 4.8). Nitrogen content can be representative of the enzyme quantity (Wei et al. 2014, Zang et al. 2013), and thus can be correlated with respiration rates.

Additionally, fine-root biomass was lower at the warmer, lower latitude sites (Figure $4.5 \& 4.6$, Table 4.5). This held true for the fine roots $(<1 \mathrm{~mm})$ at both soil depths of 0-10 and 10-20 cm (Figure $4.5 \& 4.6$ ), but fine-root biomass was generally similar among sites for the other diameter classes and soil depths $(1-2,2-5$ and $>5 \mathrm{~mm})$. The more shallow soil depth $(0-10 \mathrm{~cm})$ is dominated by $<1 \mathrm{~mm}$ roots across all sites. This soil depth is where most soils have the greatest amounts of organic matter and where all aboveground litter and most belowground litter associated with fine-root turnover occurs. As a result, this is the most active zone of nutrient uptake for this forest type. Lower fine-root biomass in the surface soil at the warmer, southern sites is not compensated for by greater fine root biomass in the $10-20 \mathrm{~cm}$ depth. We had speculated that this might occur due to a greater likelihood of drier surface soils at the warmer sites, potentially causing a redistribution of fine roots to slightly deeper soils. This notion is not supported as there is $45 \%$ less fine-root biomass $(<1 \mathrm{~mm})$ in the $10-20 \mathrm{~cm}$ depth versus the $0-10 \mathrm{~cm}$ depth at the southern sites (SOSH, NOSH, SOHO, NOHO, CEIL, see Figure 4.1, Table 4.5) versus 59\% less fine-root biomass in the same depth comparison at 
the northern sites (NOWI, FORD, ALBT, CANA, TOFT, see Figure 4.1, Table 4.5). There is a considerable mass of larger diameter roots $(2-5$ and $>5 \mathrm{~mm})$ at the $10-20 \mathrm{~cm}$ depth that remains fairly consistent across all sites. These roots are generally used for transport, carbohydrate storage and structural support so it makes sense that this is similar across all sites that have similar aboveground basal area and yearly leaf area requirements.

At the ecosystem level, lower inherent specific respiration rates and lower biomass combine to result in much lower $\mathrm{C}$ allocation to fine-root respiration at the warmer, more southern sites (Figure 4.7, Table 4.7) on the three sample dates. It should be noted that the growing season also is longer at these warmer sites, so total growing season root respiration may differ less among sites, but clearly is not greater at the warmer sites. This would agree with suggestions that ecosystem root respiration should be aligned with the work required of the root system for acquisition of nutrients (Jarvi and Burton 2015, in review), which is not expected to differ greatly along the transect, as all sites likely produce a similar biomass of nutrient rich foliage annually.

Sugar maple trees may need to have higher root biomass and specific fine-root respiration rates in the cooler more northern locations in order to obtain needed nutrients to produce similar amounts of new nutrient rich tissues (leaves, fine roots) during a shorter growing season. This shorter growing season in the northern latitudes would mean that sugar maple fine-root systems would have to conduct nutrient assimilation at a faster rate than those at southern latitudes. It appears that the northern most latitude sugar maples fine roots have a strategy of high fine-root biomass, high fine root $\mathrm{N}$ and 
metabolic capacity, coupled with lower ambient soil temperatures and a short growing season, while on the other hand, the southern-most latitude trees have a strategy of lower fine-root biomass and fine-root metabolic capacity, coupled with higher ambient soil temperatures. These strategies make intuitive sense in that high root $\mathrm{N}$ and respiratory capacity, high biomass, and warm temperatures would create a much greater capacity of the root system to do work than might be required, possibly causing the root system to use excess $\mathrm{C}$, limiting that available for other uses, including aboveground growth. This could potentially limit the trees ability to compete and survive successfully on the landscape in very warm climates.

There likely is a climatic limit beyond which sugar maple could possibly not adjust its belowground rooting strategy and $\mathrm{C}$ allocation and still remain competitive, which may be one of the reasons that sugar maple-dominated forests eventually transition to forests dominated by the beech family (Fagaceae) and hickory family (Juglandaceae) to the south. These tree families are better suited for warmer climates than sugar maple, although another maple, southern sugar maple (Acer barbatum Michx.), is sometimes treated as a subspecies of sugar maple (Desmarais 1952, Kreibel 1957) and grows in these southern regions. Southern sugar maple extends beyond sugar maple's range and reaches from Virginia to Florida and west to eastern Texas. Further work would be needed to compare sugar maple and southern sugar maple genetically and physiologically.

It is not known if the observed differences among sites are a plastic response to environmental conditions that all sugar maple are capable of, or if they are the result of 
genetically different ecotypes, tightly adapted to local climate, occurring at each site. If the former is true, climatic warming will have little impact on belowground $\mathrm{C}$ allocation across sugar maple's range. If the latter is true, ecosystem root respiration could increase greatly at all locations with climatic warming, potentially altering ecosystem carbon balance and productivity. Our own within site examination of sugar maple root respiration in experimentally warmed soil $\left(+4\right.$ to $\left.5{ }^{\circ} \mathrm{C}\right)$ at the FORD site suggests that there is some capacity for the root systems at a given location to acclimate to warmer soil (Jarvi and Burton 2013). However, acclimation was only partial and allowed for a much smaller adjustment than observed across the sugar maple transect sites. In addition, the acclimation did not involve any adjustment of root $\mathrm{N}$ concentration or fine root biomass over more than four growing seasons of warming. This suggests that the differences among sites observed along the transect may be largely due to inherent genetic differences among populations at the sites.

Overall, our data seems to indicate that within sites, climatic warming will lead to greater root system respiration, with only partial acclimation occurring. This partial acclimation would result in an overestimation of carbon effluxes due to increasing temperatures in modeling efforts with a $\mathrm{Q}_{10}$ of 2 or more. However, if the sugar maples ability to adjust $\mathrm{C}$ allocation to root system activity across its current range is indeed related to inherent differences among populations that facilitate large differences in root $\mathrm{N}$, metabolic capacity and biomass in different climates, the full adjustment to climatic warming would require the introduction at a given location of better suited genotypes.

\section{Conclusion}


Our findings suggest that factors constraining ecosystem root respiration in sugar maple across its native range may differ from those that can occur at any given location. Jarvi and Burton (2013) found that after several years of experimental soil warming a reduction in metabolic capacity occurred for sugar maple roots in experimentally warmed soil, indicating that some degree of thermal acclimation was taking place. They however saw no reduction in fine-root biomass in the same heated plots during this same time period. In another soil warming experiment with mixed hardwoods, Melillo et al. (2011) found no indication of acclimation at the tissue level, or reduction in metabolic capacity, but did find a reduction in fine-root biomass on the heated plots versus the non-heated plots. This current study found that both a reduction in fine-root biomass and a lower fine-root metabolic capacity (respiration measured across sties at a constant reference temperature of $18^{\circ} \mathrm{C}$ ) on the warmer more southern sites, showing the potential range of responses of sugar maple fine-roots to increases in warmer growing temperatures. If all sugar maple are capable of these types of changes, then sugar maple may be able to adapt to global climate change across most of its current range. However, results of soil warming experiments suggest that large reductions within a site in fine root $\mathrm{N}$ are unlikely and reductions in fine root biomass may or may not occur. A key issue may result from the rate of climatic warming combined with a reduction of woodland corridors due to agriculture and urban environments, not allowing well-suited sugar maple genotypes to naturally migrate fast enough to keep pace with climate change. Land managers may see a reduction of sugar maple in the southern extremes of its current range but presumably sugar maple will expand its range further north as global temperatures rise. Additionally, sugar maple may be able to find adequate refugia in its 
current range within north facing slopes, lower landscape positions, and more loamy soils where soil moisture is less of an issue. To maintain its full range of current landscape positions, other options, including facilitated migration of more southern genotypes, may need to be considered. 


\section{Tables and Figures}

Table 4.1 Location, mean annual temperature (MAT, $\left.{ }^{\circ} \mathrm{C}\right)$, slope $(\%)$, and aspect (degrees) for the sixteen sugar maple transect sites.

\begin{tabular}{|c|c|c|c|c|}
\hline Site & $\begin{array}{l}\text { Latitude (decimal } \\
\text { degrees) }\end{array}$ & $\begin{array}{l}\text { MAT } \\
\left({ }^{\circ} \mathrm{C}\right)\end{array}$ & $\begin{array}{l}\text { Slope } \\
(\%)\end{array}$ & $\begin{array}{c}\text { Aspect } \\
\text { (Degrees) }\end{array}$ \\
\hline $\begin{array}{l}\text { SOSH - Southern Shanwnee } \\
\text { National Forest, Southern IL }\end{array}$ & 37.58 & 13.0 & 30 & 270 \\
\hline $\begin{array}{l}\text { NOSH - Northern Shawnee } \\
\text { National Forest, Southern IL }\end{array}$ & 37.68 & 13.0 & 45 & 90 \\
\hline $\begin{array}{l}\text { SOHO - Southern Hoosier } \\
\text { National Forest, Southern IN }\end{array}$ & 38.05 & 11.7 & 25 & 340 \\
\hline $\begin{array}{l}\text { NOHO - Northern Hoosier } \\
\text { National Forest, Southern IN }\end{array}$ & 38.37 & 11.7 & 25 & 95 \\
\hline $\begin{array}{l}\text { CEIL - Funk's Grove, Central } \\
\text { Illinois }\end{array}$ & 40.35 & 10.4 & 4 & 210 \\
\hline $\begin{array}{l}\text { NOIN - Illinois Nature } \\
\text { Preserves Commision, } \\
\text { Northern Illinois }\end{array}$ & 41.57 & 9.6 & 10 & 10 \\
\hline $\begin{array}{l}\text { NOIL - Illinois Nature } \\
\text { Preserves Commision, } \\
\text { Northern Illinois }\end{array}$ & 41.85 & 9.0 & 25 & 270 \\
\hline $\begin{array}{l}\text { OCNA - Manistee National } \\
\text { Forest, Central Lower MI }\end{array}$ & 43.67 & 7.2 & 5 & 330 \\
\hline $\begin{array}{l}\text { WXLO - Manistee National } \\
\text { Forest, Central Lower MI }\end{array}$ & 44.38 & 5.9 & 10 & 30 \\
\hline $\begin{array}{l}\text { CEWI - Big Eau Pleine Woods } \\
\text { State Natural Area, Central WI }\end{array}$ & 44.73 & 4.3 & 5 & 25 \\
\hline $\begin{array}{l}\text { PELL - Mackinaw Sate Forest, } \\
\text { Northern Lower MI }\end{array}$ & 45.55 & 5.9 & 10 & 10 \\
\hline $\begin{array}{l}\text { NOWI - WI Department of } \\
\text { Natural Resources, Northern } \\
\text { WI }\end{array}$ & 46.25 & 4.3 & 5 & 30 \\
\hline $\begin{array}{l}\text { FORD - Michigan } \\
\text { Technoloigcal University, } \\
\text { Northern MI }\end{array}$ & 46.63 & 3.9 & 5 & 270 \\
\hline $\begin{array}{l}\text { ALBT - Copper Country State } \\
\text { Forest, Northern MI }\end{array}$ & 46.87 & 3.9 & $<2$ & $\mathrm{n} / \mathrm{a}$ \\
\hline $\begin{array}{l}\text { CANA - Turkey Lakes, Great } \\
\text { Lakes Forestry Centre, } \\
\text { Southern Ontario, Canada }\end{array}$ & 47.05 & 4.6 & 35 & 20 \\
\hline $\begin{array}{l}\text { TOFT - Superior National } \\
\text { Forest, Northern MN }\end{array}$ & 47.68 & 2.3 & 10 & 120 \\
\hline
\end{tabular}


Table 4.1. Continued: Tree density $\left(\right.$ trees $\left.\mathrm{ha}^{-1}\right)$, total basal area $\left(\mathrm{m}^{2} \mathrm{ha}^{-1}\right)$, sugar maple basal area (\%), and other species present for each of the sixteen transect sites.

\begin{tabular}{|c|c|c|c|c|}
\hline Site & 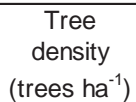 & $\begin{array}{c}\text { Total basal } \\
\text { area }\left(\mathrm{m}^{2} \mathrm{ha}^{-1}\right)\end{array}$ & $\begin{array}{c}\text { Sugar maple } \\
\text { basal area } \\
\text { (\%) }\end{array}$ & Other species present ${ }^{\star}$ \\
\hline $\begin{array}{l}\text { SOSH - Southern Shanwnee } \\
\text { National Forest, Southern IL }\end{array}$ & 541.7 & 15.5 & $71.9 \%$ & $\begin{array}{l}\text { ASTR, CACO, CAOV, FAGR, LITU, } \\
\text { OSVI, QURU }\end{array}$ \\
\hline $\begin{array}{l}\text { NOSH - Northern Shawnee } \\
\text { National Forest, Southern IL }\end{array}$ & 566.7 & 19.8 & $73.1 \%$ & $\begin{array}{l}\text { CACO, FAGR, JUNI, LITU, QUAL, } \\
\text { QURU, SAAL }\end{array}$ \\
\hline $\begin{array}{l}\text { SOHO - Southern Hoosier } \\
\text { National Forest, Southern IN }\end{array}$ & 566.7 & 18.6 & $84.0 \%$ & $\begin{array}{l}\text { CACO, FAGR, FRAM, LITU, OSVI, } \\
\text { PRSE, QUAL, QURU, SAAL, ULAM }\end{array}$ \\
\hline $\begin{array}{l}\text { NOHO - Northern Hoosier } \\
\text { National Forest, Southern IN }\end{array}$ & 516.7 & 26.0 & $93.2 \%$ & CAOV, FAGR, QUAL, QUMO \\
\hline $\begin{array}{l}\text { CEIL - Funk's Grove, Central } \\
\text { Illinois }\end{array}$ & 758.3 & 40.9 & $99.7 \%$ & ULAM \\
\hline $\begin{array}{l}\text { NOIN - Illinois Nature } \\
\text { Preserves Commision, } \\
\text { Northern Illinois }\end{array}$ & 791.7 & 24.5 & $91.6 \%$ & $\begin{array}{l}\text { CACO, JUNI, OSVI, PRSE, QUAL, } \\
\text { QURU }\end{array}$ \\
\hline $\begin{array}{l}\text { NOIL - Illinois Nature } \\
\text { Preserves Commision, } \\
\text { Northern Illinois }\end{array}$ & 966.7 & 14.4 & $73.5 \%$ & $\begin{array}{l}\text { CACO, JUNI, OSVI, PRSE, QURU, } \\
\text { ULAM }\end{array}$ \\
\hline $\begin{array}{l}\text { OCNA - Manistee National } \\
\text { Forest, Central Lower MI }\end{array}$ & 575.9 & 38.3 & $71.1 \%$ & $\begin{array}{l}\text { ACRU, FAGR, FRAM, OSVI, PRSE, } \\
\text { QURU, TSCA }\end{array}$ \\
\hline $\begin{array}{l}\text { WXLO - Manistee National } \\
\text { Forest, Central Lower MI }\end{array}$ & 542.6 & 33.7 & $78.8 \%$ & ACRU, FAGR, PRSE, QURU \\
\hline $\begin{array}{l}\text { CEWI - Big Eau Pleine } \\
\text { Woods State Natural Area, } \\
\text { Central WI }\end{array}$ & 583.3 & 37.6 & $84.6 \%$ & BEAL, CACO, FRPE, OSVI \\
\hline $\begin{array}{l}\text { PELL - Mackinaw Sate } \\
\text { Forest, Northern Lower MI }\end{array}$ & 529.6 & 33.7 & $88.8 \%$ & ACRU, FAGR, FRAM, TIAM \\
\hline $\begin{array}{l}\text { NOWI - WI Department of } \\
\text { Natural Resources, Northern } \\
\text { WI }\end{array}$ & 725.0 & 30.8 & $93.2 \%$ & $\begin{array}{l}\text { ABBA, BEPA, FRAM, OSVI, PICL, } \\
\text { TIAM }\end{array}$ \\
\hline $\begin{array}{l}\text { FORD - Michigan } \\
\text { Technoloigcal University, } \\
\text { Northern MI }\end{array}$ & 963.0 & 21.7 & $89.3 \%$ & BEAL, OSVI, TSCA, ULAM \\
\hline $\begin{array}{l}\text { ALBT - Copper Country } \\
\text { State Forest, Northern MI }\end{array}$ & 574.1 & 36.4 & $89.7 \%$ & $\begin{array}{l}\text { ACRU, ABBA, BEAL, OSVI, PIGL, } \\
\text { PRSE, TIAM }\end{array}$ \\
\hline $\begin{array}{l}\text { CANA - Turkey Lakes, Great } \\
\text { Lakes Forestry Centre, } \\
\text { Southern Ontario, Canada }\end{array}$ & 733.3 & 34.3 & $87.0 \%$ & BEAL \\
\hline $\begin{array}{l}\text { TOFT - Superior National } \\
\text { Forest, Northern MN }\end{array}$ & 1066.7 & 29.1 & $74.2 \%$ & ACRU, BEPA, POTR \\
\hline \multicolumn{5}{|c|}{$\begin{array}{l}\text { *ABBA: Abies balsamea (L.) Mill,, ACRU: Acer rubrum L., ASTR: Asimina triloba (L.) Dunal, BEAL: Betula alleghaniensis } \\
\text { Britton, BEPA: Betula papyrifera Marsh., CACO: Carya cordiformis (Wangenh.) K. Koch, CAOV: Carya ovata (Mill.) K. } \\
\text { Koch, FAGR: Fagus grandifolia Ehrh., FRAM: Fraxinus americana L, FRPE: Fraxinus pennsylvanica Marsh., JUNI: } \\
\text { Juglans nigra L., LITU: Liriodendron tulipifera L., OSVI: Ostrya viginiana (Mill.) K. Koch, PIGL: Picea glauca (Moench) } \\
\text { Voss, POTR: Populus tremuloides Michx., PRSE: Prunus serotina Ehrh., QUAL: Quercus alba L., QUMO: Quercus } \\
\text { montana Willd., QUAL: Quercus rubra L, SAAL: Sassafras albidum Nutt., TIAM: Tilia americana L., TSCA: Tsuga } \\
\text { canadensis(L.) Carr., ULAM: Ulmus americana L. }\end{array}$} \\
\hline
\end{tabular}




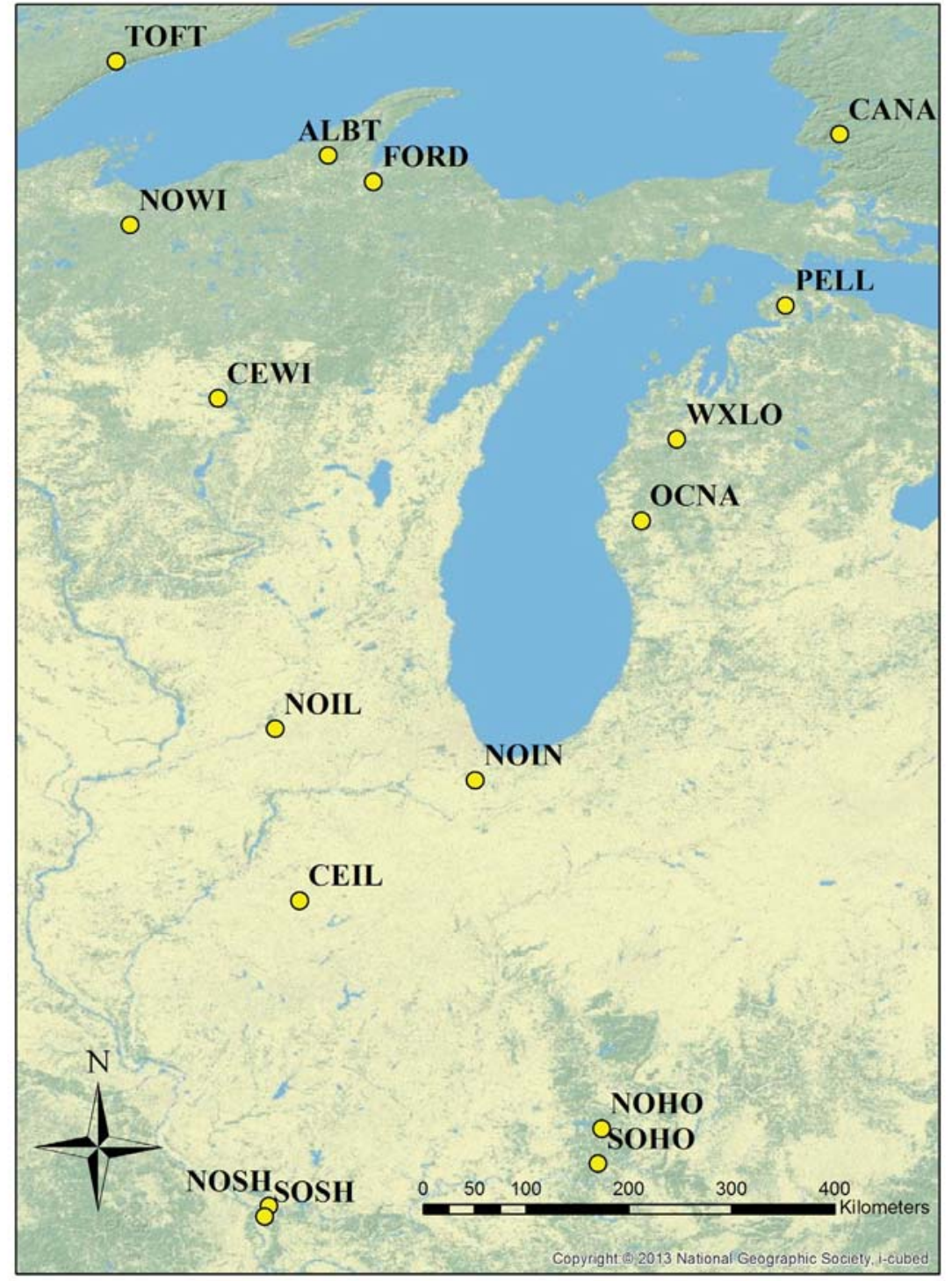

Figure 4.1 Sugar maple transect site locations in the central portion of the United States of America with four letter site location abbreviations (see Table 4.1). Open-source data from ArcGISOnline. 


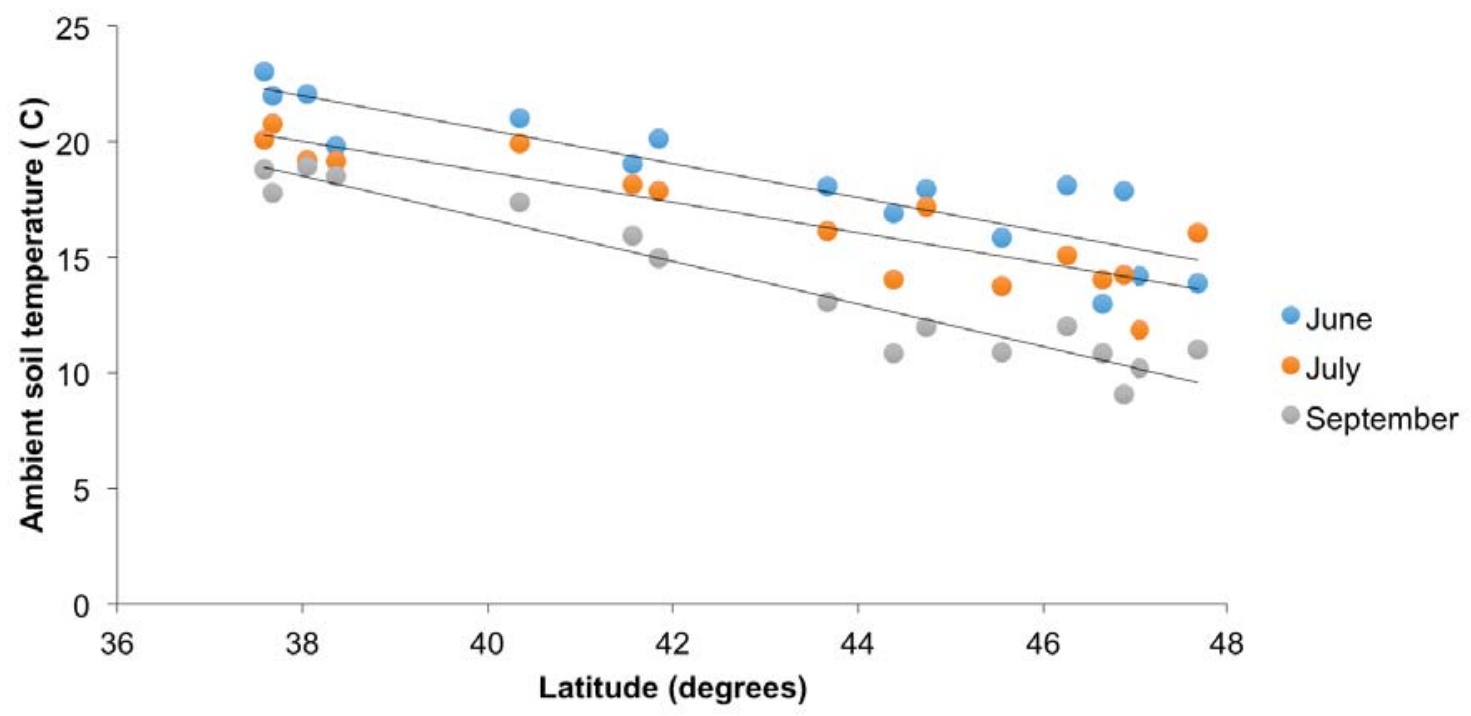

Figure 4.2 Relationships between ambient soil temperature at $0-10 \mathrm{~cm}$ and degrees of latitude for the June, July, and September 2014 dates. Slopes are not significantly different $(\mathrm{P}=0.09)$ but intercepts were $(\mathrm{P}<0.001)$. 
Table 4.2 Average soil ambient temperature and actual average reference measurement temperature by site for the June, July, and September 2014 sample dates.

\begin{tabular}{lccccccc}
\hline Site & $\begin{array}{c}\text { Latitude } \\
\text { (decimal } \\
\text { degrees) }\end{array}$ & $\begin{array}{c}\text { June } \\
\text { (ambient) }\end{array}$ & $\begin{array}{c}\text { June } \\
\text { (reference) }\end{array}$ & $\begin{array}{c}\text { July } \\
\text { (ambient) }\end{array}$ & $\begin{array}{c}\text { July } \\
\text { (reference) }\end{array}$ & $\begin{array}{c}\text { September } \\
\text { (ambient) }\end{array}$ & $\begin{array}{c}\text { September } \\
\text { (reference) }\end{array}$ \\
\hline SOSH & 37.58 & 23.0 & 18.2 & 20.1 & 18.1 & 18.8 & 18.0 \\
NOSH & 37.68 & 22.0 & 17.9 & 20.8 & 18.0 & 17.8 & 17.9 \\
SOHO & 38.05 & 22.1 & 18.4 & 19.2 & 18.0 & 18.9 & 18.0 \\
NOHO & 38.37 & 19.8 & 18.2 & 19.2 & 18.0 & 18.5 & 17.9 \\
CEIL & 40.35 & 21.0 & 18.1 & 19.9 & 17.8 & 17.4 & 18.0 \\
NOIN & 41.57 & 19.0 & 18.0 & 18.1 & 18.1 & 15.9 & 17.9 \\
NOIL & 41.85 & 20.1 & 17.9 & 17.9 & 18.0 & 14.9 & 18.0 \\
OCNA & 43.67 & 18.1 & 17.9 & 16.1 & 18.2 & 13.1 & 17.8 \\
WXLO & 44.38 & 16.9 & 18.1 & 14.1 & 17.8 & 10.9 & 17.9 \\
CEW & 44.73 & 18.0 & 17.9 & 17.2 & 18.2 & 12.0 & 18.0 \\
PELL & 45.55 & 15.9 & 17.9 & 13.8 & 17.8 & 10.9 & 18.3 \\
NOW & 46.25 & 18.1 & 18.0 & 15.1 & 17.9 & 12.0 & 17.9 \\
FORD & 46.63 & 13.0 & 17.9 & 14.0 & 17.9 & 10.8 & 18.2 \\
ALBT & 46.87 & 17.9 & 18.2 & 14.2 & 18.0 & 9.1 & 18.1 \\
CANA & 47.05 & 14.2 & 18.0 & 11.9 & 17.8 & 10.2 & 18.3 \\
TOFT & 47.68 & 13.9 & 17.8 & 16.1 & 18.1 & 11.0 & 17.8
\end{tabular}



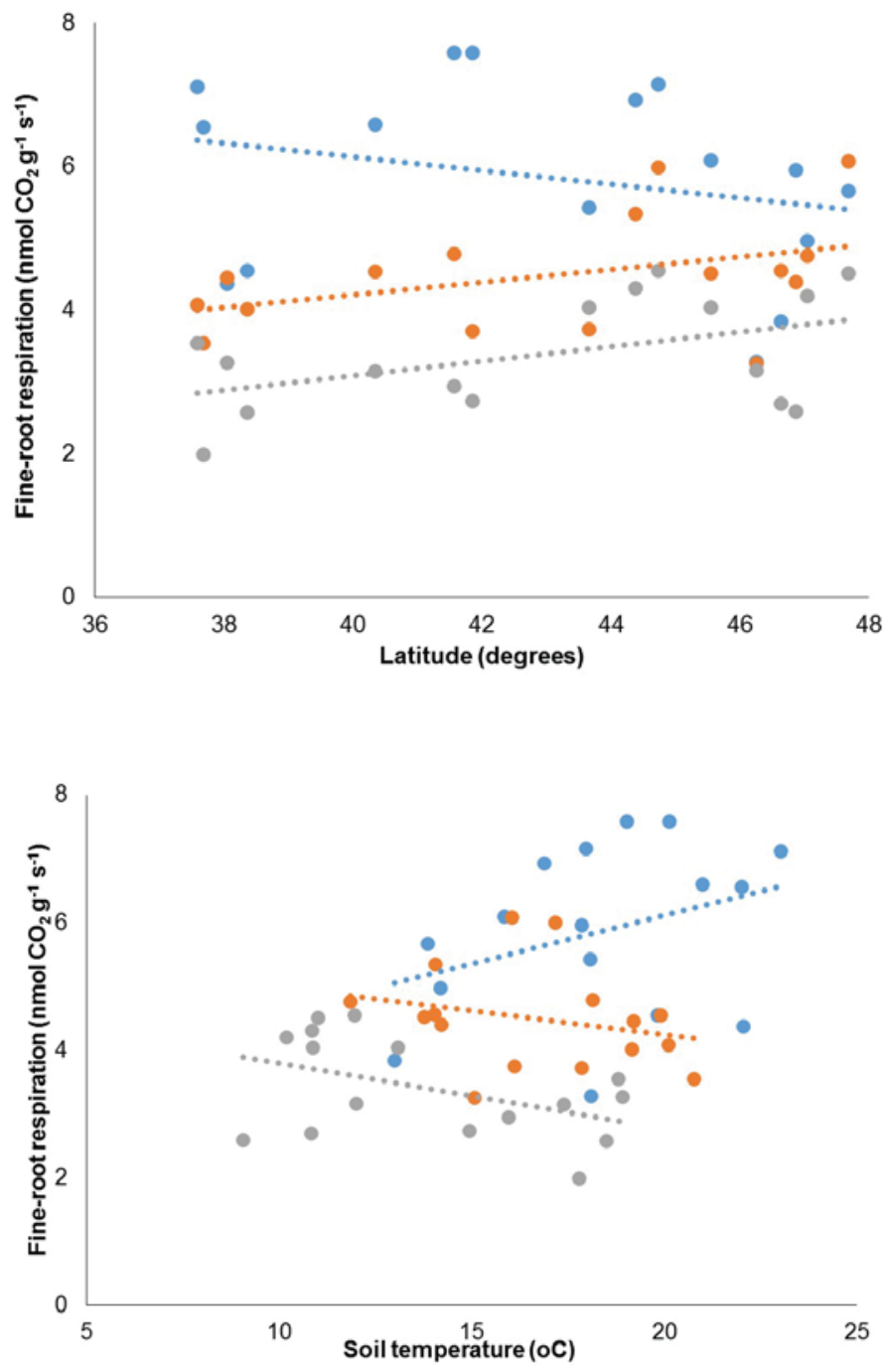

Figure 4.3 Specific fine-root respiration at ambient soil temperature versus latitude for the June (blue), July (orange), and September (grey) sample dates (top plate), and specific fine-root respiration at ambient soil temperature across versus temperature (bottom plate). 
Table 4.3 Average fine-root respiration ( $\left.\mathrm{nmol} \mathrm{CO}_{2} \mathrm{~g}^{-1} \mathrm{~s}^{-1}\right)$ and average soil temperature $\left({ }^{\circ} \mathrm{C}\right)$ across sites for June, July, and September 2015.

\begin{tabular}{|c|c|c|c|c|c|c|}
\hline \multirow[b]{2}{*}{$\begin{array}{c}\text { Site } \\
\text { Location }\end{array}$} & \multicolumn{2}{|c|}{ June } & \multicolumn{2}{|c|}{ July } & \multicolumn{2}{|c|}{ September } \\
\hline & $\begin{array}{c}\text { Root } \\
\text { Respiration }\end{array}$ & $\begin{array}{c}\text { Soil } \\
\text { Temperature }\end{array}$ & $\begin{array}{c}\text { Root } \\
\text { Respiration }\end{array}$ & $\begin{array}{c}\text { Soil } \\
\text { Temperature }\end{array}$ & $\begin{array}{c}\text { Root } \\
\text { Respiration }\end{array}$ & $\begin{array}{c}\text { Soil } \\
\text { Temperature }\end{array}$ \\
\hline SOSH & 7.1 & 23.0 & 4.1 & 20.1 & 3.5 & 18.8 \\
\hline NOSH & 6.6 & 22.0 & 3.5 & 20.8 & 2.0 & 17.8 \\
\hline $\mathrm{SOHO}$ & 4.4 & 22.1 & 4.5 & 19.2 & 3.3 & 18.9 \\
\hline $\mathrm{NOHO}$ & 4.5 & 19.8 & 4.0 & 19.2 & 2.6 & 18.5 \\
\hline CEIL & 6.6 & 21.0 & 4.5 & 19.9 & 3.1 & 17.4 \\
\hline NOIN & 7.6 & 19.0 & 4.8 & 18.1 & 2.9 & 15.9 \\
\hline NOIL & 7.6 & 20.1 & 3.7 & 17.9 & 2.7 & 14.9 \\
\hline OCNA & 5.4 & 18.1 & 3.7 & 16.1 & 4.0 & 13.1 \\
\hline WXLO & 6.9 & 16.9 & 5.3 & 14.1 & 4.3 & 10.9 \\
\hline CEWI & 7.2 & 18.0 & 6.0 & 17.2 & 4.5 & 12.0 \\
\hline PELL & 6.1 & 15.9 & 4.5 & 13.8 & 4.0 & 10.9 \\
\hline NOWI & 3.3 & 18.1 & 3.3 & 15.1 & 3.2 & 12.0 \\
\hline FORD & 3.8 & 13.0 & 4.6 & 14.0 & 2.7 & 10.8 \\
\hline ALBT & 6.0 & 17.9 & 4.4 & 14.2 & 2.6 & 9.1 \\
\hline CANA & 5.0 & 14.2 & 4.8 & 11.9 & 4.2 & 10.2 \\
\hline TOFT & 5.7 & 13.9 & 6.1 & 16.1 & 4.5 & 11.0 \\
\hline
\end{tabular}

Table 4.4 Repeated measures analysis of variance (ANOVA) results for specific fine-root respiration at ambient soil temperature and a reference temperature of $18^{\circ} \mathrm{C}$.

\begin{tabular}{|c|c|c|c|c|c|c|}
\hline \multirow{3}{*}{$\begin{array}{l}\text { Fine-root respiration at } \\
\text { Ambient Temperature }\end{array}$} & & d.f. & Sum Sq & Mean Sq & F value & P-value \\
\hline & $\begin{array}{l}\text { Between } \\
\text { Site } \\
\text { Residuals }\end{array}$ & $\begin{array}{l}15 \\
80\end{array}$ & $\begin{array}{l}142.4 \\
125.1\end{array}$ & $\begin{array}{c}9.5 \\
1.56\end{array}$ & 6.01 & $<0.001$ \\
\hline & $\begin{array}{l}\text { Within } \\
\text { Date } \\
\text { Site x Date } \\
\text { Residuals }\end{array}$ & $\begin{array}{c}2 \\
30 \\
160\end{array}$ & $\begin{array}{l}291.7 \\
135.1 \\
199.7\end{array}$ & $\begin{array}{c}145.86 \\
4.5 \\
1.25\end{array}$ & $\begin{array}{c}116.84 \\
3.61\end{array}$ & $\begin{array}{l}<0.001 \\
<0.001\end{array}$ \\
\hline $\begin{array}{l}\text { Fine-root respiration at } \\
\text { Reference Temperature }\end{array}$ & $\begin{array}{l}\text { Between } \\
\text { Site } \\
\text { Residuals } \\
\text { Within } \\
\text { Date } \\
\text { Site x Date } \\
\text { Residuals }\end{array}$ & $\begin{array}{c}2 \\
30 \\
160\end{array}$ & $\begin{array}{c}14.51 \\
110.46 \\
280.26\end{array}$ & $\begin{array}{c}61.24 \\
1.97\end{array}$ & $\begin{array}{c}4.14 \\
2.1\end{array}$ & $\begin{array}{l}0.018 \\
0.002\end{array}$ \\
\hline
\end{tabular}



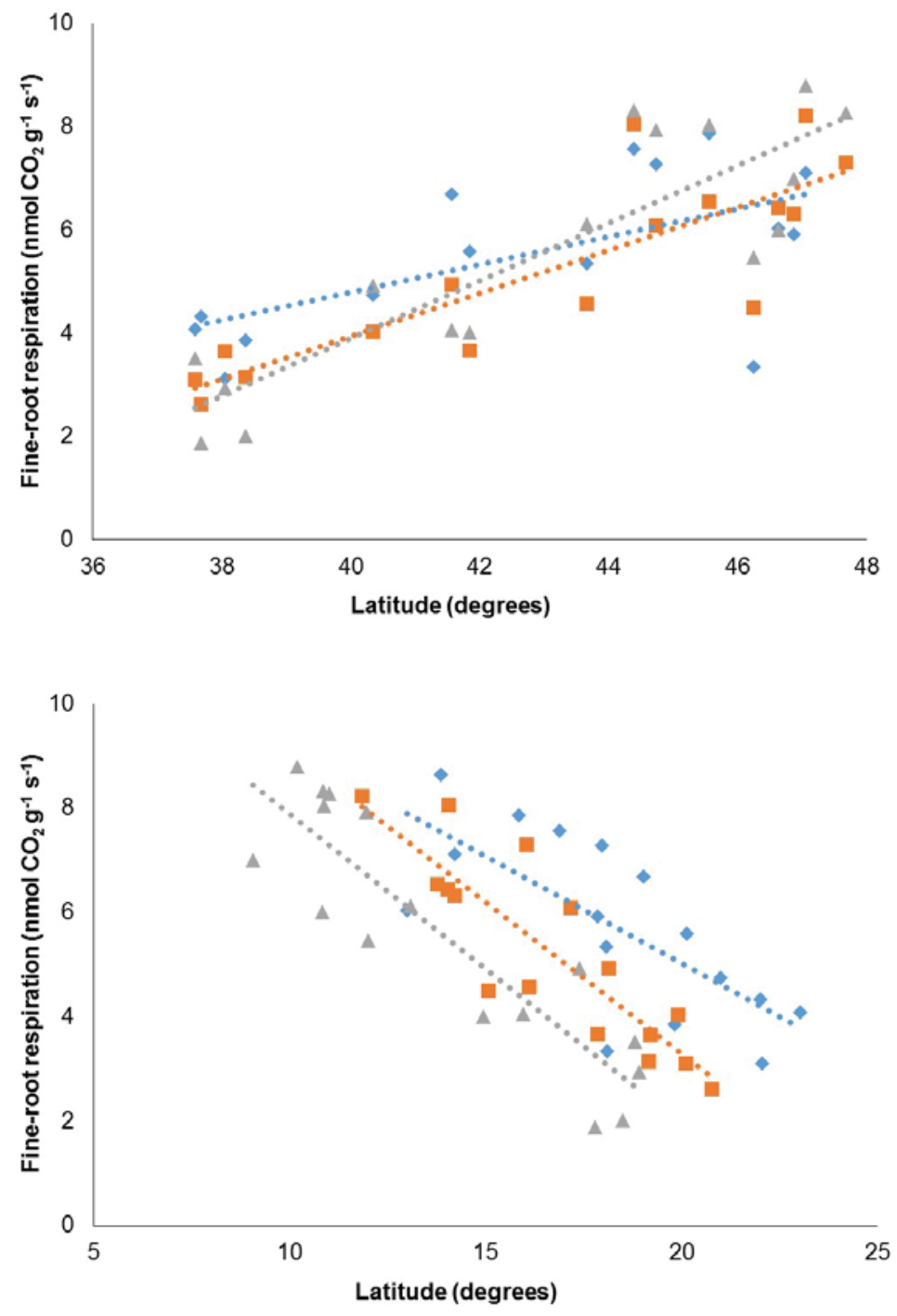

Figure 4.4 Average specific fine-root respiration at a reference temperature of $18{ }^{\circ} \mathrm{C}$ versus latitude for the June (blue), July (orange), and September (grey) 2014 sample dates (top plate), and average specific fine-root respiration at a reference temperature of $18{ }^{\circ} \mathrm{C}$ versus ambient soil temperature (bottom plate). 
Table 4.5 Average root biomass across sites for soil depths of 0-10 and 10-20 cm across root diameters of $<1,1-2.2-5$, and $>5 \mathrm{~mm}$. Pearson's correlation coefficient and associated $P$-value for each average biomass with latitudes included.

\begin{tabular}{|c|c|c|c|c|c|}
\hline \multirow{2}{*}{ Site } & \multirow{2}{*}{$\begin{array}{l}\text { Latitude (decimal } \\
\text { degrees) }\end{array}$} & \multicolumn{4}{|c|}{ Depth $(0-10 \mathrm{~cm})$} \\
\hline & & $<1 \mathrm{~mm}$ & $1-2 \mathrm{~mm}$ & $2-5 \mathrm{~mm}$ & $>5 \mathrm{~mm}$ \\
\hline SOSH & 37.58 & 106.2 & 54.0 & 36.0 & - \\
\hline NOSH & 37.68 & 79.8 & 26.4 & 20.7 & 36.2 \\
\hline SOHO & 38.05 & 156.7 & 31.1 & 57.2 & - \\
\hline NOHO & 38.37 & 159.6 & 52.5 & 39.5 & - \\
\hline CEIL & 40.35 & 82.6 & 12.3 & - & - \\
\hline NOIN & 41.57 & 97.0 & 7.5 & 11.1 & 50.7 \\
\hline NOIL & 41.85 & 120.8 & 32.2 & 18.3 & - \\
\hline OCNA & 43.67 & 289.5 & 27.5 & 39.5 & 74.6 \\
\hline WXLO & 44.38 & 237.3 & 17.4 & 40.9 & - \\
\hline CEWI & 44.73 & 166.6 & 38.7 & 23.6 & - \\
\hline PELL & 45.55 & 378.1 & 16.8 & 9.0 & - \\
\hline NOWI & 46.25 & 461.6 & 46.5 & 48.0 & 30.5 \\
\hline FORD & 46.63 & 393.2 & 49.0 & 17.9 & 78.1 \\
\hline ALBT & 46.87 & 501.4 & 40.4 & 26.3 & 97.1 \\
\hline CANA & 47.05 & 230.6 & 60.1 & 38.5 & - \\
\hline TOFT & 47.68 & 436.4 & 29.4 & 34.1 & - \\
\hline $\begin{array}{l}\text { Pearson's } \\
\text { Correlation } \\
\text { Coefficeint (R) }\end{array}$ & & 0.80 & -0.01 & -0.27 & 0.20 \\
\hline \multirow[t]{2}{*}{$\begin{array}{l}\text { Linear correlation } \\
\text { P-value }\end{array}$} & & $<0.001$ & 0.97 & 0.33 & 0.71 \\
\hline & & \multicolumn{4}{|c|}{ Depth $(10-20 \mathrm{~cm})$} \\
\hline SOSH & 37.58 & 64.409793 & 23.36819 & 47.101375 & - \\
\hline NOSH & 37.68 & 49.457717 & 11.365785 & 38.6216 & 182.931 \\
\hline SOHO & 38.05 & 43.759546 & 61.667235 & 23.639814 & - \\
\hline NOHO & 38.37 & 108.61243 & 82.336157 & 123.58912 & 108.149 \\
\hline CEIL & 40.35 & 53.806254 & 25.303514 & 103.73507 & - \\
\hline NOIN & 41.57 & 52.220647 & 46.795797 & 83.210448 & 177.71 \\
\hline NOIL & 41.85 & 56.300955 & 70.528983 & 19.803119 & - \\
\hline OCNA & 43.67 & 82.264856 & 25.736415 & 14.684696 & - \\
\hline WXLO & 44.38 & 91.565022 & 1.7485823 & 130.81263 & - \\
\hline CEWI & 44.73 & 63.010927 & 16.170142 & 70.028175 & - \\
\hline PELL & 45.55 & 81.925325 & 22.646687 & 40.794595 & - \\
\hline NOWI & 46.25 & 261.43512 & 36.983365 & 49.690295 & - \\
\hline FORD & 46.63 & 229.02269 & 45.819647 & 63.899649 & 169.791 \\
\hline ALBT & 46.87 & 155.01267 & 71.581527 & 159.98679 & 218.751 \\
\hline CANA & 47.05 & 71.97708 & 31.797036 & 55.012437 & 101.834 \\
\hline TOFT & 47.68 & 108.09464 & 30.167289 & 12.3674 & - \\
\hline $\begin{array}{l}\text { Pearson's } \\
\text { Correlation } \\
\text { Coefficeint (R) }\end{array}$ & & 0.55 & -0.10 & -0.06 & 0.12 \\
\hline $\begin{array}{l}\text { Linear correlation } \\
\text { P-value }\end{array}$ & & 0.03 & 0.70 & 0.81 & 0.82 \\
\hline
\end{tabular}



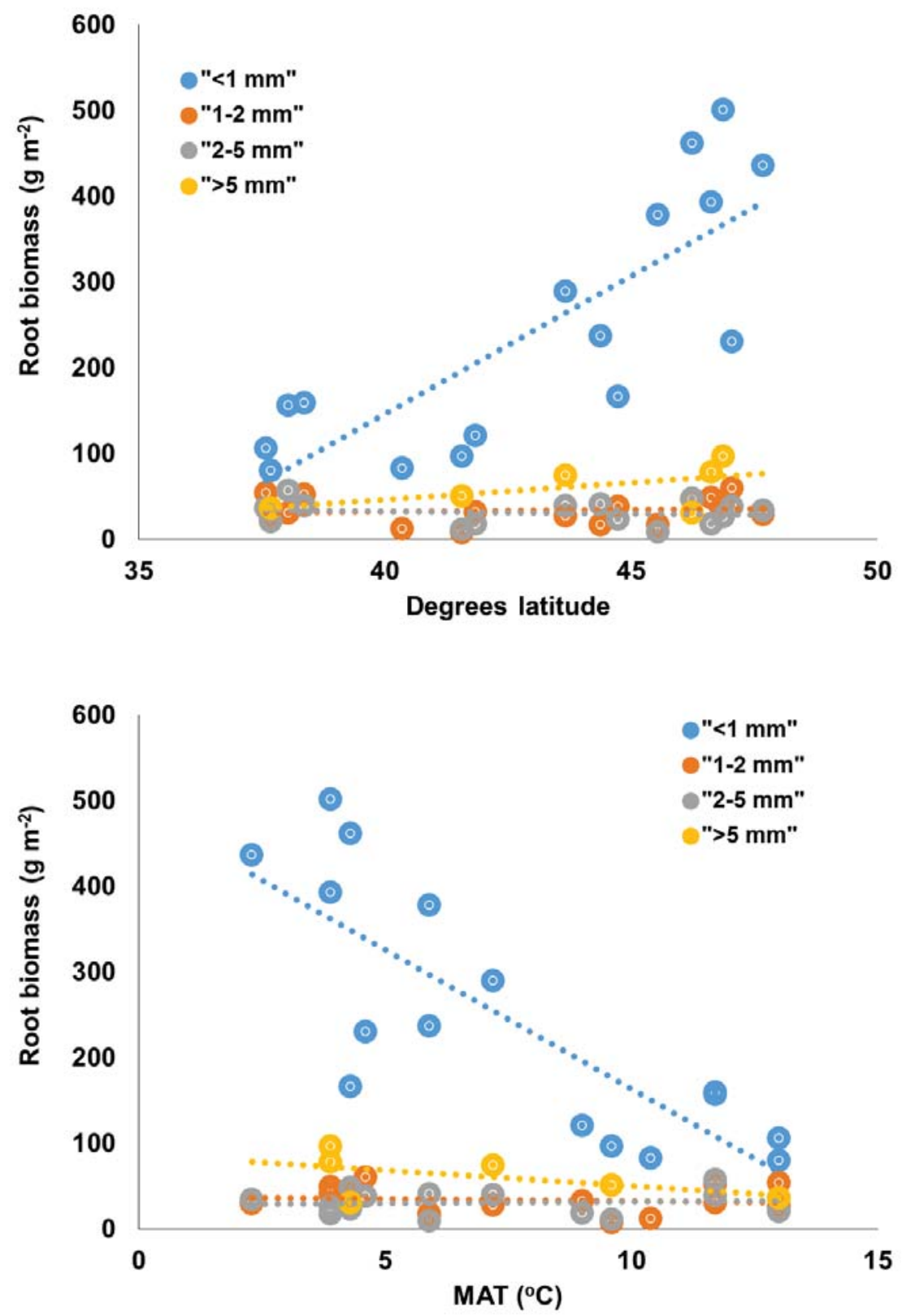

Figure 4.5 Average root biomass for the $0-10 \mathrm{~cm}$ soil depth versus latitude for root diameters of $<1,1-2,2-5$ and $>5 \mathrm{~mm}$ (top plate), with average root biomass versus mean annual temperature at same depths and root diameters (bottom plate). 

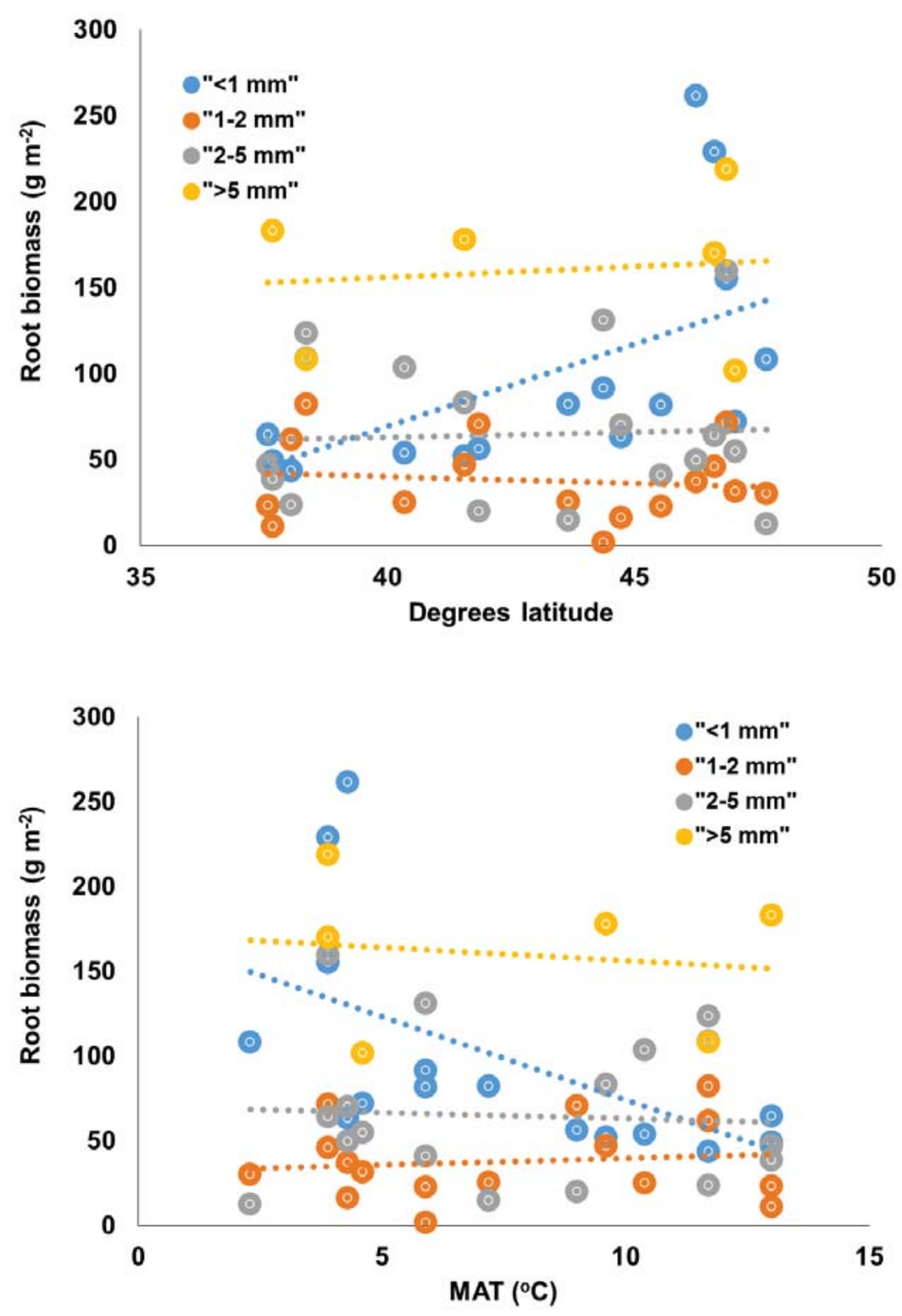

Figure 4.6 Average root biomass for the 10-20 $\mathrm{cm}$ soil depth versus latitude for root diameters of $<1,1-2,2-5,>5 \mathrm{~mm}$ (top plate), and average root biomass versus mean annual temperature for same depth and root diameters (bottom plate). 
Table 4.6 Three-way analysis of variance (ANOVA) for root biomass across site, sample depth $(0-10,10-20 \mathrm{~cm})$, and root diameter $(<1,1-2,2-5,>5 \mathrm{~mm})$.

\begin{tabular}{lccccc}
\hline & d.f. & Sum Sq & Mean Sq & F value & P-value \\
\hline & & & & & \\
Site & 15 & 897104 & 59807 & 4.205 & $<0.001$ \\
Sample depth & 1 & 44023 & 44023 & 3.095 & 0.079 \\
Root diameter & 3 & 2414806 & 804935 & 56.598 & $<0.001$ \\
Site x Sample depth & 15 & 271004 & 18067 & 1.27 & 0.215 \\
Site x Root diameter & 45 & 1585096 & 35224 & 2.477 & $<0.001$ \\
Sample depth x Root diameter & 3 & 1052600 & 350867 & 24.671 & $<0.001$ \\
Site x Sample Depth x Root diameter & 45 & 554966 & 12333 & 0.867 & 0.718 \\
Residuals & 640 & 9101990 & 14222 & & \\
\hline
\end{tabular}

Table 4.7 Repeated measures ANOVA for ecosystem fine-root respiration at ambient temperature as a product of specific fine-root respiration at ambient temperature and fine root biomass.

\begin{tabular}{llccccc}
\hline & & d.f. & Sum Sq & Mean Sq & F value & P-value \\
\hline $\begin{array}{l}\text { Ecosystem } \\
\text { Respiration }\end{array}$ & Between & & & & & \\
& $\begin{array}{l}\text { Site } \\
\text { Residuals }\end{array}$ & 15 & 107.98 & 7.2 & 7.347 & $<0.001$ \\
& & & & & & \\
& Within & & & & & \\
& Date & 2 & 12.57 & 6.29 & 50.37 & $<0.001$ \\
& Site x Date & 30 & 8.97 & 0.3 & 2.4 & $<0.001$ \\
& Residuals & 160 & 19.97 & 0.125 & & \\
\hline
\end{tabular}



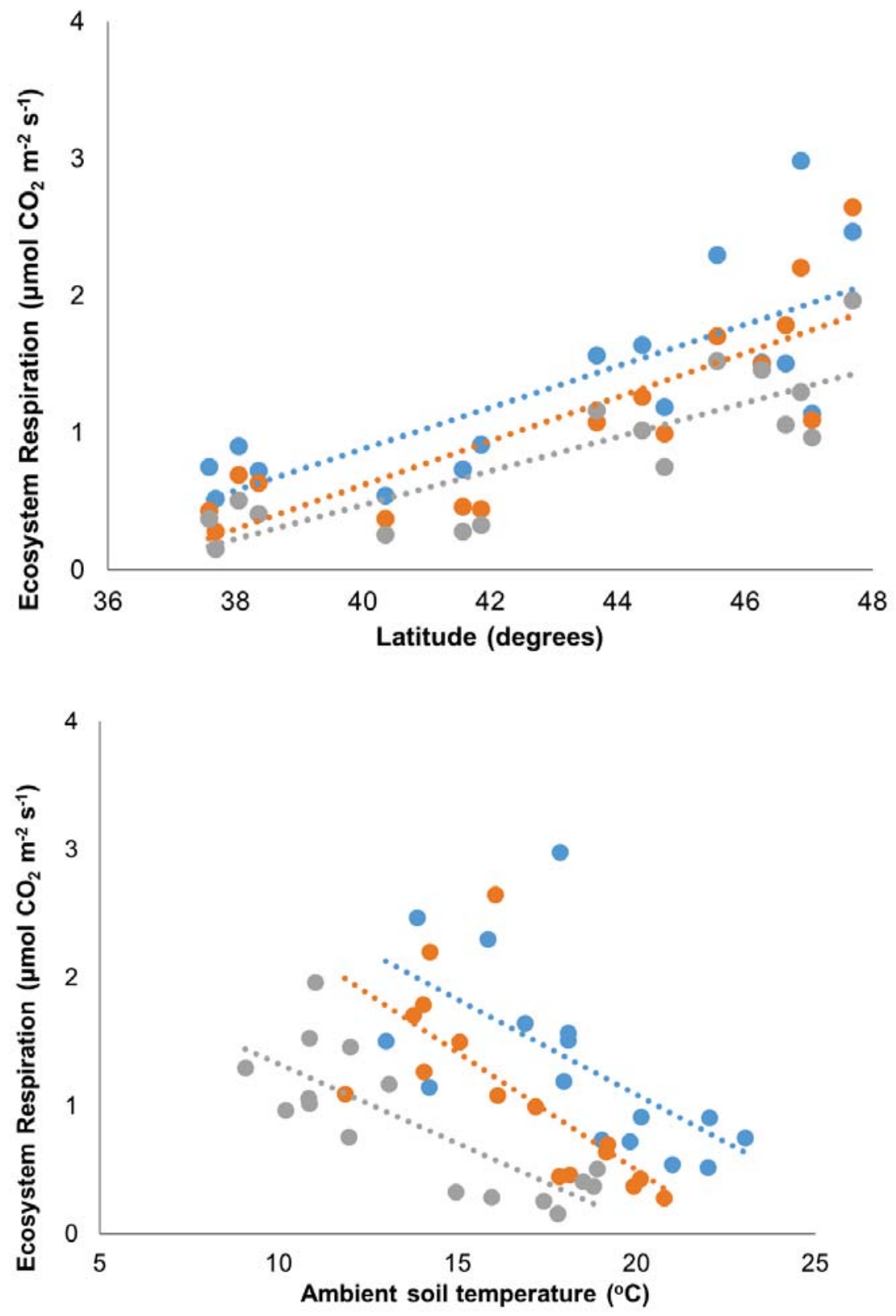

Figure 4.7 Average ecosystem fine-root respiration $\left(\mu \mathrm{mol} \mathrm{CO} \mathrm{Cm}^{-2} \mathrm{~s}^{-1}\right)$ versus latitude for the June (blue), July (orange), and September (grey) 2014 sample dates (top plate), and average ecosystem fine-root respiration versus ambient soil temperature (bottom plate). 

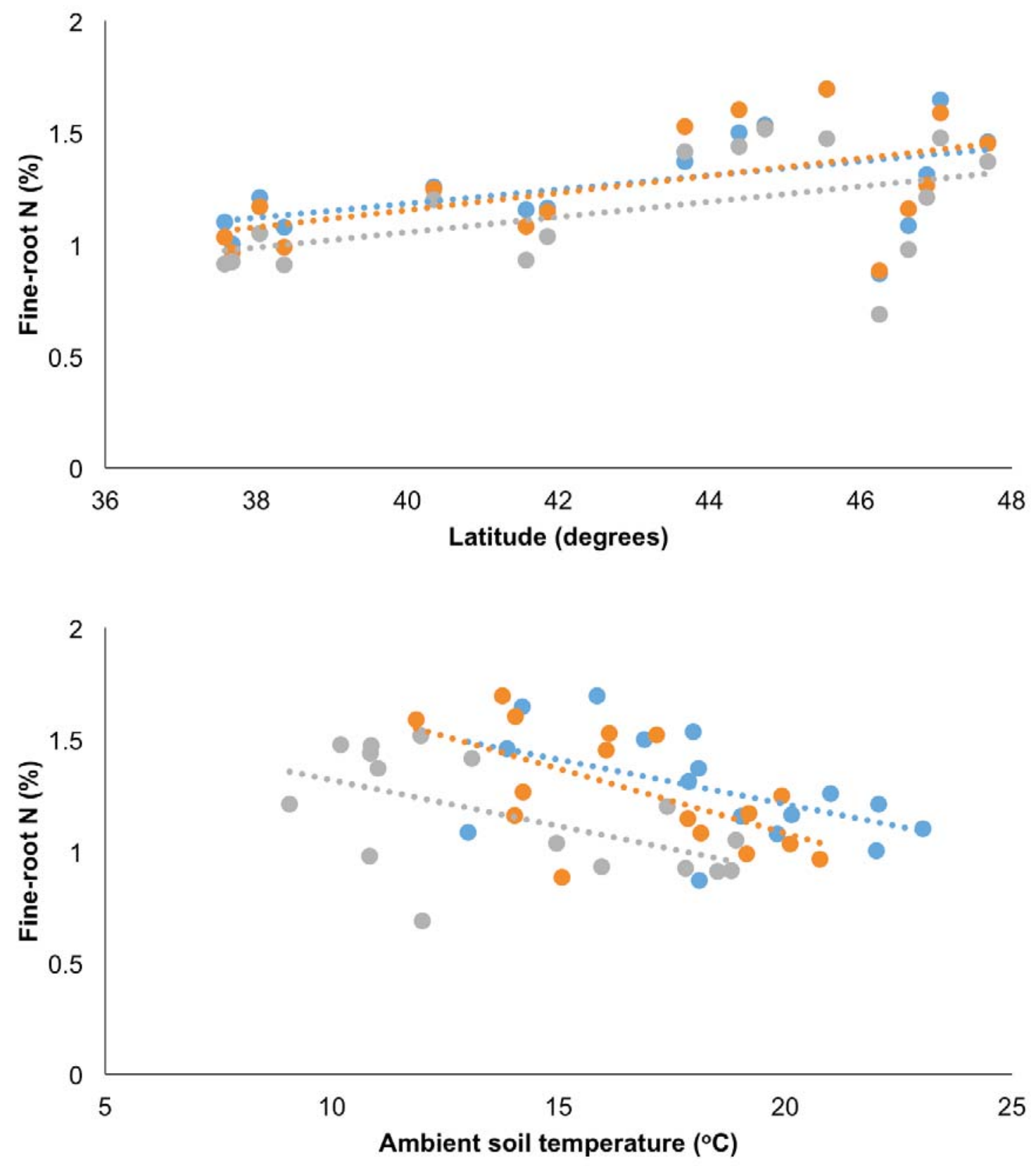

Figure 4.8 Average fine-root $\mathrm{N}$ concentration versus latitude for the June, July, and September sample dates (top plate), and average fine-root $\mathrm{N}$ concentration versus ambient soil temperature (bottom plate). 


\section{References}

Atkin O.K., Bloomfield K.J., Reich P.B., Tjoelker M.G., Asner G.P., Bonal D., \& Sitch S. (2015) Global variability in leaf respiration in relation to climate, plant functional types and leaf traits. New Phytologist 206(2):614-636.

Atkin O.K., Edwards E.J., Loveys B.R. (2000b) Response of root respiration to changes in temperature and its relevance to global warming. New Phytologist 147:141-154.

Atkin O.K., Holly C., Ball M.C. (2000a) Acclimation of snow gum (Eucalyptus pauciflora) leaf respiration to seasonal and diurnal variations in temperature: the importance of changes in the capacity and temperature sensitivity of respiration. Plant, Cell and Environment 23:15-26.

Atkin O.K., Sherlock D., Fitter A.H., Jarvis S., Hughes J.K., Campbell C., Hurry V., Hodge A. (2009) Temperature dependence of respiration in roots colonized by arbuscular mycorrhizal fungi. New Phytologist 182(1):188-199.

Atkin O.K., Tjoelker M.G. (2003) Thermal acclimation and the dynamic response of plant respiration to temperature. Trends in Plant Science. 8(7):343-351.

Atkinson L.J., Hellicar M.A., Fitter A.H., Atkin O.K. (2007) Impact of temperature on the relationship between respiration and nitrogen concentration in roots: an analysis of scaling relationships, Q(10) values and thermal acclimation ratios. New Phytologist. 173(1):110-120.

Bond-Lamberty B., Thomson A. (2010) Temperature-associated increases in the global soil respiration record. Nature 464:579-582.

Bowden R.D., Nadelhoffer K.J., Boone R.D., Melillo J.M., Garrison J.B. (1993) Contributions of aboveground litter, belowground litter, and root respiration to total soil respiration in a temperate mixed hardwood forest. Canadian Journal of Forest Research. 23:1402-1407.

Burton A.J., Jarvey J.C., Jarvi M.P., Zak D.R., Pregitzer K.S. (2012) Chronic N deposition alters root respiration-tissue $\mathrm{N}$ relationship in northern hardwood forests. Global Change Biology 18:258-266

Burton A.J., Pregitzer K.S., Ruess R.W., Hendrick R.L., Allen M.F. (2002) Root respiration in North American forests: effects of nitrogen concentration and temperature across biomes. Oecologia 131:559-568.

Burton A.J., Zogg G.P., Pregitzer K.S., Zak D.R. (1997) Effect of measurement CO2 concentration on sugar maple root respiration. Tree Physiology. 17(7):421-427.

Cao M.K., Woodward F.I. (1998) Dynamic responses of terrestrial ecosystem carbon cycling to global climate change. Nature 393:249-252. 
Cooper E.J. (2004) Out of sight, out of mind: thermal acclimation of root respiration in arctic Ranunculus. Arctic, Antarctic, and Alpine Research 36:308-313.

Covey-Crump E.M., Attwood R.G., Atkin O.K. (2002) Regulation of root respiration in two species of Plantago that differ in relative growth rate: the effect of short- and longterm changes in temperature. Plant, Cell and Environment. 25(11):1501-1513.

Cox P.M., Betts R.A., Jones C.D., S. Spall S.A., Totterdell I.J. (2000) Acceleration of global warming due to carbon-cycle feedbacks in a coupled climate model. Nature 408:184-187.

Davidson E.A., Janssens I.A. (2006) Temperature sensitivity of soil carbon decomposition and feedbacks to climate change. Nature 440:165-173.

DeLucia E.H., Drake J.E., Thomas R.B., Gonzalez-Meler M. (2007) Forest carbon use efficiency: is respiration a constant fraction of gross primary production? Global Change Biology. 13:1157-1167.

Desmarais Y. (1952) Dynamics of leaf variation in the sugar maples. Brittonia 7:347387.

Edwards E.J., Benham D.G., Marland L.A., Fitter A.H. (2004) Root production is determined by radiation flux in a temperate grassland community. Global Change Biology. 10(2):209-227.

Epron D., Farque L., Lucot E., Badot P.M. (1999) Soil CO2 efflux in a beech forest: the contribution of root respiration. Annals of Forest Science. 56:289-295.

IPCC (2013a): Summary for Policymakers. In: Climate Change 2013: The Physical Science Basis. Contribution of Working Group I to the Fifth Assessment Report of the Intergovernmental Panel on Climate Change [Stocker, T.F., D. Qin, G.-K. Plattner, M. Tignor, S.K. Allen, J. Boschung, A. Nauels, Y. Xia, V. Bex and P.M. Midgley (eds.)]. Cambridge University Press, Cambridge, United Kingdom and New York, NY, USA.

IPCC (2013b): Annex I: Atlas of Global and Regional Climate Projections [van Oldenborgh, G.J., M. Collins, J. Arblaster, J.H. Christensen, J. Marotzke, S.B. Power, M. Rummukainen and T. Zhou (eds.)] In: Climate Change 2013: The Physical Science Basis. Contribution of Working Group I to the Fifth Assessment Report of the Intergovernmental Panel on Climate Change [Stocker, T.F., D. Qin, G. -K. Plattner, M. Tignor, S.K. Allen, J. Boschung, A. Nauels, Y. Xia, V. Bex and P.M. Midgley (eds.)] Cambridge University Press, Cambridge, United Kingdom and New York, NY, USA.

Jarvi M.P. (2011) The effects of a changing climate on root respiration of woody plants in sugar maple forests and northern peatlands. MS Thesis. Michigan Technological University. 
Jarvi M.P., Burton A.J. (2013) Acclimation and soil moisture constrain sugar maple root respiration in experimentally warmed soil. Tree physiology,33(9), 949-959.

Kreibel H.B. (1957) Patterns of genetic variation in sugar maple. Ohio Agric. Exp. Sta. Bull. 791, Columbus.

Larigauderie A., Körner C. (1995) Acclimation of leaf dark respiration to temperature in alpine and lowland plant species. Annals of Botany 76:245-252.

Litton C.M., Raich J.W., Ryan M.G. (2007) Carbon allocation in forest ecosystems. Global Change Biology, 13(10), 2089-2109.

Loveys B.R., Atkinson L.J., Sherlock D.J., Roberts R.L., Fitter A.H., Atkin O.K. (2003) Thermal acclimation of leaf and root respiration: an investigation comparing inherently fast- and slow growing plant species. Global Change Biology 9:895-910.

Lu M., Zhou X.H., Yang Q., Li H., Luo Y.Q., Fang C.M., Chen J.K., Yang X., Li B. (2013) Responses of ecosystem carbon cycle to experimental warming: a metaanalysis. Ecology, 94(3), 726-738.

Luo Y.Q., Wan S.Q., Hui D.F., Wallace L.L. (2001) Acclimatization of soil respiration to warming in a tall grass prairie. Nature 413:622-625.

Luyssaert S., Inglima I., Jungs M., Richardson A.D., Reichstein M., Papale D., Piao S.L., Schulze E.D., Wingate L., Matteucci G., Aragao L., Aubinet M., Beer C., Bernhofer C., Black K.G., Bonal D., Bonnefond J.M., Chambers J., Ciais P., Cook B., Davis K.J., Dolman A.J., Gielen B., Goulden M., Grace J., Granier A., Grelle A., Griffis T., Grünwald T., Guidolotti G., Hanson P.J., Harding R., Hollinger D.Y., Hutyra L.R., Kolari P., Kruijt B., Kutsch W., Loustau D., Malhi Y., Mateu J., Migliavacca M., Misson L., Montagnani L., Moncrieff J., Moors E., Munger J.W., Nikinmaa E., Ollinger S.V., Pita G., Rebmann C., Roupsard O., Saigusa N., Sanz M.J., Seufert G., Sierra C., Smith M.L., Tang J., Valentini R., Vesala T., Janssens I.A. (2007) CO2 balance of boreal, temperate, and tropical forests derived from a global database. Global Change Biology. 13:2509-2537.

Melillo J.M., Butler S., Johnson J., Mohan J., Steudler P., Lux H., Burrows E., Bowles F., Smith R., Scott L., Vario C., Hill T., Burton A., Zhou YM., Tang J. (2011) Soil warming, carbon-nitrogen interactions and forest carbon budgets. Proceedings of the National Academy of Science 108:9508-9512.

Melillo J.M., Steudler P.A., Aber J.D., Newkirk K., Lux H., Bowles F.P., Catricala C., Magill A., Ahrens T., Morrisseau S. (2002) Soil warming and carbon-cycle feedbacks to the climate system. Science 298:2173-2176.

Nakane K., Kohno T., Horikoshi T. (1996) Root respiration rate before and just after clear- felling in a mature, deciduous, broad-leaved forest. Ecological Research. 11:111119. 
Nemani R.R., Keeling C.D., Hashimoto H., Jolly W.M., Piper S.C., Tucker C.J., Myneni R.B., Running S.W. (2003) Climate-driven increases in global terrestrial net primary production from 1982 to 1999 . Science 300:1560- 1563.

Oleson, K.W., Lawrence D.M., Bonan G.B., Flanner M.G., Kluzek E., Lawrence P.J., Levis S., Swenson S.C., Thornton P.E., Dai A., Decker M., Dickinson R., Feddema J., Heald C.L., Hoffman F., Lamarque J.-F., Mahowald N., Niu G.-Y., Qian T., Randerson J., Running S., Sakaguchi K., Slater A., Stockli R., Wang A., Yang Z.-.L., Zeng Xi., and Zeng Xu. (2010) Technical Description of version 4.0 of the Community Land Model (CLM). NCAR Technical Note NCAR/TN-478+STR, National Center for Atmospheric Research, Boulder, CO, 257 pp.

Ow L.F., Griffin K.L., Whitehead D., Walcroft A.S., Turnbull M.H. (2008) Thermal acclimation of leaf respiration but not photosynthesis in Populus deltoides $\times$ nigra. New Phytologist, 178(1), 123-134.

Petchey O.L., McPhearson P.T., Casey T.M., Morin P.J. (1999) Environmental warming alters food-web structure and ecosystem function. Nature 402:69-72.

Piao S., Luyssaert S., Ciais P., Janssens I.A., Chen A., Cao C., Fang J., Friedlingstein P., Luo Y., Wang S. (2010) Forest annual carbon cost: a global-scale analysis of autotrophic respiration. Ecology. 91(3):652-661.

Pregitzer K.S., Laskowski M.J., Burton A.J., Lessard V.C., Zak D.R. (1998) Variation in sugar maple root respiration with root diameter and soil depth. Tree Physiology. 18:665670 .

Prentice I.C., Farquhar G.D., Fasham, Goulden M.L., Heimann M., Jaramillo V.J., Kheshgi H.S., LeQuere C., Scholes R.H., Wallace Douglas W.R. (2001) The carbon cycle and atmospheric carbon dioxide. In Climate Change 2001: The Scientific Basis: Contribution of Working Group I to the Third Assesment Report of the Intergovernmental Panel on Climate Change (eds J.T. Houghton, Y. Ding et al.), pp. 183237. Cambridge University Press, Cambridge.

R Development Core Team (2008) R: A language and environment for statistical computing. R Foundation for Statistical Computing, Vienna, Austria. ISBN 3-900051-070, URL http://www.R-project.org.

Ryan M.G., Lavigne M.B., Gower S.T. (1997) Annual carbon cost of autotrophic respiration in boreal forest ecosystems in relation to species and climate. Journal of Geophysical Research-Atmospheres. 102:28871-28883.

Slot M., \& Kitajima K. (2015) General patterns of acclimation of leaf respiration to elevated temperatures across biomes and plant types. Oecologia 177(3):885-900. 
Smith, N.G., Dukes J.S. (2013) Plant respiration and photosynthesis in global-scale models: incorporating acclimation to temperature and CO2. Global Change Biology 19:45-63.

Smith P., Fang C.M. (2010) Carbon cycle: a warm response by soils. Nature 464:499500 .

Tjoelker M.G., Oleksyn J., Reich P.B. (2001) Modelling respiration of vegetation: evidence for a general temperature-dependent Q(10). Global Change Biology. 7:223-230.

Vanderwel M.C., Slot M., Lichstein J.W., Reich P.B., Kattge J., Atkin O.K., \& Kitajima, K. (2015) Global convergence in leaf respiration from estimates of thermal acclimation across time and space. New Phytologist.

Walker M.D., Wahren C.H., Hollister R.D., Henry G.H., Ahlquist L.E., Alatalo J.M., Bret-Harte M.S., Calef M.P., Callaghan T.V., Carroll A.B., Epstein H.E., Jónsdóttir I.S., Klein J.A., Magnússon B., Molau U., Oberbauer S.F., Rewa S.P., Robinson C.H., Shaver G.R., Suding K.N., Thompson C.C., Tolvanen A., Totland Ø., Turner P.L., Tweedie C.E., Webber P.J., Wookey P.A. (2006) Plant community responses to experimental warming across the tundra biome. Proceedings of the National Academy of Sciences of the United States of America, 103(5), 1342-1346.

Wei D., Zhou B., Ma X., Chen X., Zhang J. (2014) Soil microbial properties of black soil under long-term fertilisation. Acta Agriculturae Scandinavica, Section B-Soil \& Plant Science, 63(sup2), 195-199.

Woodwell G.M., Mackenzie F.T. (eds.) (1995) Biotic feedbacks in the global climatic system: will the warming feed the warming? Oxford University Press, Oxford.

Zhang X., Huang G., Bian X., Zhao Q. (2013) Effects of nitrogen fertilization and root interaction on the agronomic traits of intercropped maize, and the quantity of microorganisms and activity of enzymes in the rhizosphere. Plant and soil, 368(1-2), 407-417. 


\section{Chapter 5: Conclusion}

Throughout the four plus years of warming in the SMART experiment, surface fine-root respiration was elevated, but not to the degree that would be predicted for a 4 to $5{ }^{\circ} \mathrm{C}$ increase in soil temperature. Instead, as described in Chapter 2, partial acclimation of fine-root respiration occurred. An examination of potential causal mechanisms suggested fine root respiration at the SMART experiment was constrained by adenylate control. There was no evidence that the fine-roots were using their allocated amount of carbohydrates from photosynthesis too quickly due to increased temperatures and thus increased respiration (i.e. substrate limitation). If this had been the case we would have observed decreased amounts of sugars (glucose, fructose, and galactose) in the fine-roots from the heated treatments. Additionally, we did not observe evidence for a general decrease in the amount of enzymes in the roots used to conduct respiration, as this would be expected to result in lower root $\mathrm{N}$ concentrations, which did not occur.

We did observe clear evidence that the fine root respiration was constrained by adenylate control. Use of a respiratory uncoupler resulted in increased respiration rates for all treatments, with the greatest relative enhancement occurring for roots from warmed soil. The uncoupler allows respiration to occur without creation of adenosine triphosphate (ATP). This causes adenosine diphosphate (ADP) concentrations to remain high, eliminating low ADP (or high ATP) concentrations as signaling mechanisms that could slow respiration due to insufficient use of ATP (i.e. ATP exceeding that required for cellular metabolism). Since the response was greatest for roots from warmed soils, 
this suggests ATP was not being fully utilized, and fine-root respiration was being down regulated as a result.

We hypothesize that ATP was not being fully used in the fine roots from warmed soil because there was not a large increase in nutrient acquisition that could take place. Net $\mathrm{N}$ mineralization on the heated and non-heated treatments has been measured at this location since 2010 and was initially greatly elevated on the heated treatments, but every subsequent year decreased slightly. In 2013 when this part of the study was conducted net $\mathrm{N}$ mineralization was only $28 \%$ greater on the heated treatments versus the nonheated treatments. In addition, the annual production of $\mathrm{N}$ rich biomass (leaves and fine roots) should have remained relatively unchanged on the warmed plots, thus plant nutrient demand would not have increased as much as root potential metabolic capacity did with warming.

Partial thermal acclimation of respiration occurred for the surface fine roots $(<1$ $\mathrm{mm}$ at $0-10 \mathrm{~cm}$ ) throughout the duration of the SMART experiment, causing a $32 \%$ increase in respiration with warming, which is far less than the $71 \%$ that might have been predicted for a 4 to $5{ }^{\circ} \mathrm{C}$ soil temperature increase. Surface fine roots can account for as much as half of ecosystem respiration, but the response of larger diameter and deeper roots also needed to be investigated. In Chapter 3, we found evidence partial acclimation was also occurring in the surface 1-2 mm roots. However, there was no apparent acclimation of the large diameter surface roots $(2-10 \mathrm{~mm}$ at $0-10 \mathrm{~cm}$ depth) or any roots deeper in the soil $(<1,1-2$, and 2-10 $\mathrm{mm}$ diameter at $10-30 \mathrm{~cm}$ or $30-50 \mathrm{~cm}$ depths $)$. This makes intuitive sense in that the smaller diameter roots $(<1 \mathrm{~mm}, 1-2 \mathrm{~mm})$ at the shallow 
soil depth $(0-10 \mathrm{~cm})$ are the most active portions of the soil in terms of nutrient acquisition. This is where the highest amount of root respiration occurs comparatively to other soil depths. The other diameter classes at the other depths are away from the majority of nutrient acquisition and conduct most of the storage, transport and water acquisition for the tree. A higher proportion of their respiration is associated with maintenance respiration, and it is conceivable that the maintenance portion of respiration would increase as temperature increases. Additionally, there was no adjustment of root biomass of any root diameter or rooting depth class, which is confirmatory of Jarvi and Burton (2013) for the SMART experiment.

When both specific root respiration and root biomass are combined into ecosystem root respiration rates $\left(\mu \mathrm{mol} \mathrm{CO}_{2} \mathrm{~m}^{-2} \mathrm{~s}^{-1}\right)$, it becomes apparent that although there has been a reduction in shallow soil depth root respiration of smaller root diameters $(<1$ and $1-2 \mathrm{~mm})$, there is still $60 \%$ more ecosystem root respiration on the heated treatments versus the non-heated treatments. This increased loss in $\mathrm{C}$ back to the atmosphere cannot be used for additional respiration or other uses such as aboveground biomass production.

As a complement to work conducted at the SMART experiment, where the soil of sugar maple forests was experimentally warmed, Chapter 4describes a study conducted using the temperature gradient existing across the entire native range of sugar maple. The goal of this work was to determine how fine root respiration measured at sixteen different locations across the region responded to temperature both within and across sites. Given a $10{ }^{\circ} \mathrm{C}$ difference in mean annual temperature across the 16 sites, it was 
expected that there might be differences among populations in inherent respiration rates, allowing southern, warmer populations to avoid excessive root system respiration that would be in excess of that needed for root system work (i.e. nutrient acquisition).

Within each site, root respiration increased with temperature across sample dates, but there were large inherent differences in metabolic capacity among the populations at the sites, wherein specific fine-root respiration was actually higher at the cooler and more northern sites when compared to the warmer more southern sites for two of three sampling dates, despite soil temperatures nearly $10^{\circ} \mathrm{C}$ cooler. Additionally, there was greater fine-root biomass at the more northern and cooler sites when compared to the southern sites. Ultimately, ecosystem level fine-root respiration at ambient temperature was actually greater at the northern and cooler sites than the warmer southern sites for the June, July and September sampling periods. This contrasts with what models might predict across the temperature range studied. The differences among populations were associated with lower metabolic capacity at the warmer sites, as fine-root respiration at a common reference temperature of $18{ }^{\circ} \mathrm{C}$ and fine root $\mathrm{N}$ concentration were much lower at the southern, warmer sites.

It is currently not known if sugar maple throughout the entire native range are capable of the range of adjustments to temperatures as across the latitudinal transect sites, indicating a plastic phenotypic response to climatic conditions. Our results also could result from a genotypic response in which there are different temperature races within sugar maple that are adapted to different climatic conditions. The former would indicate that sugar maple may be able to adjust to predicted future climate warming and may only 
be at risk of decreased abundance in the southern extremes of its current native range. However, if the latter is true and sugar maple populations at any given location are adapted to their local climate, with only a limited ability to adjust, then this species is at risk to adverse effects of climate change in terms of abundance and competitiveness throughout its current range. The lack of changes in root $\mathrm{N}$ concentration or biomass after four plus years of experimental warming in the SMART study suggests this may indeed be the case. 


\section{References}

Jarvi M.P., Burton A.J. (2013) Acclimation and soil moisture constrain sugar maple root respiration in experimentally warmed soil. Tree physiology, 33(9), 949-959. 